\title{
Live benthic foraminiferal faunas from the French Mediterranean Coast: Towards a new biotic index of environmental quality
}

\author{
Christine Barras $^{\mathrm{a}, *}$, Frans J. Jorissen ${ }^{\mathrm{a}}$, Céline Labrune ${ }^{\mathrm{b}, \mathrm{c}}$, Bruno Andral ${ }^{\mathrm{d}}$, Pierre Boissery ${ }^{\mathrm{e}}$
}

\author{
a LUNAM Université, Université d"Angers, UMR CNRS 6112 LPGN-BIAF - Laboratoire des Bio-Indicateurs \\ Actuels et Fossiles - 2 Boulevard Lavoisier - 49045 Angers Cedex, France \\ ${ }^{b}$ UPMC, Université Paris 06, Observatoire Océanologique - 66650 Banyuls/Mer, France \\ c UMR CNRS 8222 LECOB, Observatoire Océanologique - 66650 Banyuls/Mer, France \\ d IFREMER, Laboratoire Environnement Ressources Provence-Azur-Corse, Centre Méditerranée - Zone \\ Portuaire de Brégaillon - BP 330 - 83507 La Seyne-sur-Mer Cedex, France \\ e Agence de I"Eau Rhône-Méditerranée et Corse, 2-4 allée de Lodz - 69363 Lyon Cedex 07, France \\ *: Corresponding author : Christine Barras, Tel.: +332417350 02 ; \\ email address : christine.barras@univ-angers.fr
}

\begin{abstract}
:
In this study, living (Rose Bengal stained) foraminiferal faunas from 31 stations along the entire French Mediterranean Sea coast except Corsica have been analysed. In the context of the Water Framework Directive, the aim was to develop a biotic index to evaluate the benthic ecosystem quality. Therefore, different faunal parameters (diversity indices, wall structure proportion, and indicative species groups) have been tested to determine their relevance as indicators of environmental conditions. The best results are obtained with a biotic index based on the relative proportion of stress-tolerant taxa. For ecosystem quality evaluation, it is essential to distinguish between natural and anthropogenic eutrophication phenomena. In order to do so, we applied a correction on our biotic index, using the expected percentage of stress-tolerant species in natural environments, in function of sediment grain size (percentage $<63 \mu \mathrm{m}$ ). Finally, a comparison of the different faunal parameters calculated for two different sediment intervals $(0-1$ and $0-4 \mathrm{~cm})$ indicates clearly that the analysis of the uppermost centimetre of the sediment is sufficient to obtain relevant information needed for bio-monitoring purposes.
\end{abstract}

\section{Highlights}

Development of a biotic index based on benthic foraminiferal faunas. Discriminate between natural and anthropogenic eutrophication. Relevance of foraminiferal parameters for the development of biotic index. - Inventory of living benthic foraminiferal faunas of the French Mediterranean coast. Restrict faunal analysis to the first $\mathrm{cm}$ of sediment for bio-monitoring studies.

Keywords: Coastal Mediterranean Sea ; Foraminiferal faunas ; Indicative species ; Tolerant species ; Biotic index ; Water Framework Directive 


\section{Introduction}

Due to their strategic location at the interface of marine and terrestrial areas, coastal ecosystems have been impacted by human activities since the advent of human societies. Anthropogenic impact in coastal marine ecosystems has multiple origins, such as urban sewage, industrial and agricultural activities or fisheries, and results in environmental problems, such as eutrophication, oxygen deficiency, chemical pollution or physical disturbance. Awareness of recent changes in ecological conditions in many coastal seas has fostered a need to assess increasing anthropogenic pressures and their consequences on sediment and water quality, and to suggest measures to reverse this trend. In this context, the European commission implemented the Water Framework Directive (WFD, Directive 2008/56/EC) with the aim to obtain (or to maintain) a "good status" for all the European waters by 2015. The WFD defines the ecological status as the quality of the structure and functioning of ecosystems and is assessed using different planktonic and benthic indicators (e.g. phytoplankton, macro-algae, angiosperms, fish faunas and soft substrate benthic invertebrate fauna) (Devlin et al., 2007).

The study of the benthic macrofauna is the traditional tool for benthic ecological quality assessment and bio-monitoring studies, since macrofauna responds in a predictable way to anthropogenic and natural stress (Pearson and Rosenberg, 1978). Environmental managers 
need an easily interpretable ecological quality status based on quantitative data. Numerous biotic indicator methods were developed for macrofauna (see review in Diaz et al., 2004) based either on diversity indices (e.g. Shannon index, Pielou, 1975) or on indices based on the relative proportions of faunal groups with different ecological characteristics. Some of the latter methods are based on groups with different feeding strategies (e.g. ITI, Word, 1979), whereas others distinguish several classes of pollution-sensitive versus opportunistic, pollution-tolerant, species (e.g. AMBI, Borja et al., 2000; BENTIX, Simboura and Zenetos, 2002; BOPA, Gomez Gesteira and Dauvin, 2002, Dauvin and Ruellet, 2007; BQI, Rosenberg et al., 2004).

More recently, benthic foraminiferal faunas have been increasingly used as bio-indicators of anthropogenic pollution. Initially, foraminifera were mainly studied in fossil records for biostratigraphic and paleoenvironmental purposes. The interest for the living organisms greatly expanded when researchers started to study their ecology in the $1960^{\circ e}$ s. Because of their short life cycle (3 months to 2 years, Murray, 1991), these organisms are able to respond rapidly to environmental changes, with a change in diversity and in species composition. Such rapid adaptive responses have been observed in response to changes in the quantity and quality of organic supplies (e.g. Altenbach and Sarnthein, 1989; Corliss and Emerson, 1990; Corliss, 1991; Herguera and Berger, 1991; Rathburn and Corliss, 1994; Jorissen et al., 1995, 1998; De Rijk et al., 2000; Licari et al., 2003), in oxygen conditions (e.g. Sen Gupta and Machain-Castillo, 1993 ; Gooday, 1994 ; Jorissen et al., 1995 ; Gooday et al., 2000), pH (e.g. Murray, 1989), salinity and temperature (e.g. Murray, 2006). Moreover, foraminifera are ubiquitous in marine environments, inhabiting transitional to abyssal areas and tropical to polar latitudes (review in Murray, 2006). Foraminifera are abundant in marine sediments, even in deep-sea environments where they commonly represent more than $50 \%$ of the total biomass (Gooday et al., 1992). The high number of individuals sampled with a little quantity of sediment assures the robustness of data analysis and limits the impact of sampling on the seafloor. Furthermore, foraminiferal taxonomy is easy compared to the identification of macrofauna, since only a single biological group is considered, instead of several phyla. Although foraminifera represent only a part of the trophic niches and guilds, the ecological characteristics of the different species are different enough to obtain reliable information about the environmental conditions, as it has been shown in a wide range of papers on benthic foraminiferal ecology (e.g. Gooday and Rathburn, 1999; Jorissen et al., 2007; Murray, 2006). Finally, the main advantage of foraminifera is the conservation of a large part of their tests (shells) in the sediment after their death. The study of dead faunas at different depths in the 
sediment can give important information about the natural conditions which existed before a site became polluted. This is especially useful in case of the absence of an environmental baseline study (Alve, 1995). Comparison of living faunas and pre-impact faunas can also yield essential information about individual species ecological strategies. For example, opportunistic species which have colonised the area, or sensitive species which disappear from the area after the onset of pollution, can easily be recognised. As such, the comparison of live and dead faunas can ensure that lists with species ecological characteristics correctly translate the behaviour of the various species at the study site.

All these advantages make foraminifera an innovative and very interesting tool for biomonitoring studies of anthropogenic impact (reviews in Alve, 1995; Nigam et al., 2006; Frontalini and Coccioni, 2011). The first studies using foraminifera as indicators of environmental quality appeared in the $1960^{\text {ee }}$ (Resig, 1960; Watkins, 1961; Bandy et al., 1964, 1965; Seiglie, 1968, 1971; Clark, 1971). Today, numerous studies use foraminifera as bio-indicators of different types of pollution such as eutrophication (e.g. Platon et al., 2005; Mojtahid et al., 2008; Hyams-Kaphzan et al., 2009), heavy metals (e.g. Alve, 1991; Armynot du Châtelet et al., 2004; Frontalini et al., 2008; Bergamin et al., 2009; Cherchi et al., 2009; Coccioni et al. 2009; Frontalini et al., 2009; Romano et al., 2009; Vilela et al., 2011), urban sewage (e.g. Burone et al., 2006; Teodoro et al., 2010), oil drilling activities (e.g. Durrieu et al., 2006; Mojtahid et al. 2006; Duchemin et al. 2008; Jorissen et al., 2009; Denoyelle et al., 2010), oil spills (e.g. Morvan et al., 2004) or aquaculture (e.g. Bouchet et al., 2007). However, no standardised protocols for sampling and sampling treatment have been defined until recently (Schönfeld et al., 2012) so that direct comparison of the various studies is very difficult, if not impossible. However, a careful observation of the faunal patterns described in these studies allows identifying different types of species behaviour in response to pollution. Just as for macrofauna, some studies tried to develop biotic indices, either based on faunal diversity (e.g. Bouchet et al., 2012) or on the proportion of indicative species (e.g. Mojtahid et al. 2006; Jorissen et al., 2009).

In the present study, we analyse living (Rose Bengal stained) foraminiferal faunas from the French Mediterranean Sea coast (except Corsica) in the context of the WFD, with the aim to evaluate the ecosystem quality. The study area represents more than $1000 \mathrm{~km}$ of coastal zone for which the presence of anthropogenic stress parameters is badly known. There are no point sources of pollution close to sampling stations, and there are no well-defined reference stations exempt of any anthropogenic impact either. Therefore, we first analysed the various 
135 faunal parameters (faunal density, diversity and faunal composition) that could be used for the

136 evaluation of the environmental quality. Next, we tried to take into account the natural

137 variability of the system in order to distinguish between the impact of this natural variability

138 and a putative anthropogenic impact. Unfortunately, our study was performed prior to the

139 establishment of a standardised sampling and sampling treatment protocol by the FOBIMO

140 group (Schönfeld et al., 2012), and therefore does not follow all recommendations made in

141 this paper. However, by comparing the faunal data for the $0-1 \mathrm{~cm}$ and $0-4 \mathrm{~cm}$ sediment levels,

142 we tested the possibility to restrict faunal analyses to the topmost centimetre, as recommended

143 by Schönfeld et al. (2012). By studying only the topmost centimetre, the time needed for

144 picking the foraminifera would be largely reduced, making the method better adapted for

145 cost-efficient bio-monitoring studies. This study represents the first crucial step for the

146 development of a new biotic index based on benthic foraminiferal faunas. In order to be used

147 routinely in future surveys, the presented index will need to be tested in cases with a strong

148 pollution gradient and in other geographic areas. Since it is the first large scale study of living

149 foraminiferal faunas along the entire French Mediterranean coast (except Corsica), the results

150 of the present study can also serve as a global inventory and a baseline for future studies.

\section{Material and methods}

\subsection{Regional setting of the study area}

154 The Mediterranean Sea is generally considered as a semi-enclosed oligotrophic basin. Low

155 salinity surface water from the Atlantic Ocean enters the Mediterranean Sea through the Strait

156 of Gibraltar and creates the Liguro-Provencal Current (LPC) which flows along the French

157 Mediterranean coast, from Italy to Spain through the Gulf of Lion (Millot and Taupier-Letage,

158 2005; Pairaud and Desmare, 2011). The LPC can develop small scale gyres, depending of the

159 background stratification or external forcing that can influence the shelf circulation.

160 There is a clear difference in the continental shelf characteristics along the Mediterranean

161 French coast. The continental shelf in front of the Provence Alpe Côte deAzur region is

162 relatively narrow, less than 1 mile wide (Pairaud and Desmare, 2011). East of Toulon, an area

163 with rocky sea floor is interrupted by several small embayments containing more fine-grained

164 sediments, such as the Bay of Villefranche, between Villefranche and Nice. On the western

165 side of the French Mediterranean coast, the continental shelf of the Gulf of Lion is wide (up to

16640 miles; Bassetti et al., 2006) and consists of a large crescent shaped area incised by sub- 
167

168

169

170

171

172

173

174

175

176

177

178

179

180

181

182

183

184

185

186

187

188

189

190

191

192

193

194

195

196

197

marine canyons (Berné and Gorini, 2005). The bottom sediment distribution displays a midshelf mud belt and the inner and outer shelf regions with mixed sandy to muddy deposits (Aloisi et al., 1973).

The Gulf of Lions is also strongly influenced by the Rhône River input (Raimbault and Durrieu de Madron, 2003). With a mean annual discharge of $1700 \mathrm{~m}^{3} / \mathrm{s}$ (Thill et al., 2001), the Rhône is one of the main sources of freshwater and organic carbon for the Mediterranean Sea (Pont, 1997; Sempéré et al., 2000). The Rhône River has a mean sediment discharge of about $9.9 \pm 6.410^{9} \mathrm{Kg} / \mathrm{yr}$ (Sempéré et al., 2000; Pont et al., 2002), accounting for $80 \%$ of the riverine input to the Gulf of Lions (Durrieu de Madron et al., 2000). The Rhône prodelta is characterized by silty muds with high organic carbon content (1-2\%; Durrieu de Madron et al., 2000) and very high sediment accumulation rates. Also smaller coastal rivers (e.g. the Têt and Hérault Rivers) can significantly contribute to the sediment budget in this area (Kim et al., 2006).

Finally, this part of the Mediterranean Sea is characterised by endemic Posidonia seagrass meadows. In our study area, Posidonia meadows are located in front of Banyuls-sur-Mer (Blanc-Vernet, 1969, 1984; Vénec-Peyré and Le Calvez, 1981, 1988; Vénec-Peyré, 1984) and form a continuous band from the east side of the Rhône prodelta to the Italian frontier (Boudouresque et al., 2006).

\subsection{Sampling strategy}

From March $26^{\text {th }}$ to April $9^{\text {th }} 2009,31$ stations were sampled for the study of benthic foraminiferal faunas along the French Mediterranean coast on board of the research vessel "Europe" (Figure 1, Appendix A). The location of the stations was chosen according to the WFD criteria, i.e. within one mile from the coastline and at least one station per water body (i.e., a coherent geographic area based on physical (e.g. hydrodynamic, sedimentological) criteria influencing biological activities).

\subsection{Foraminiferal sampling methods}

Surface sediment was sampled using a Reineck box corer, which was subsampled with plexiglass cores (diameter $7.1 \mathrm{~cm}$ ). Only station Cerbère could be sampled with an interface corer (Gemax twin corer, core diameter $8.8 \mathrm{~cm}$ ). 
198 On board, cores were sliced horizontally, every half centimetre from the surface to $2 \mathrm{~cm}$ depth, 199 every centimetre between 2 and $6 \mathrm{~cm}$ depth, and every two centimetres from 6 to $10 \mathrm{~cm}$ depth. 200 Sometimes, cores were too short to sample until $10 \mathrm{~cm}$ depth. For stations Gruissan, Lavandou 201 and Faraman, it was not possible to take a core in the Reineck box (e.g. because of the 202 presence of many pebbles), and the first centimetre of the surface was sampled with a spoon.

203 In this case, after homogenization, $50 \mathrm{~cm}^{3}$ of sediment was subsampled for foraminiferal 204 analyses.

205 After sampling, sediments were stored in plastic bottles filled with a mixture of ethanol (95\%) 206 and Rose Bengal stain (1g/1). Rose Bengal is commonly used to obtain a rapid overview of the 207 living faunas. It stains the cytoplasm of foraminifera alive at the time of sampling (Walton, 208 1952), or which died in a recent past (weeks to months, Bernhard, 1988; Corliss and Emerson, 209 1990), and in which the non degraded proteins are still stainable. Ethanol allows preserving 210 stained cellular tissues for a prolonged period of time. Samples were gently shaken to obtain a 211 homogeneous mixture and were transported to the laboratory for further processing.

\subsection{Foraminiferal analyses}

214 In the laboratory, sediment samples treated with Rose Bengal were sieved through 150 and, if 215 necessary, $500 \mu \mathrm{m}$ mesh screens. For our study, only the $>150 \mu \mathrm{m}$ or $150-500 \mu \mathrm{m}$ fraction was 216 analysed, depending on the station. The $>500 \mu \mathrm{m}$ size fraction was removed when the 217 sediment contained large quantities of vegetal detritus, shell fragments or coarse sand, which 218 complicated foraminiferal picking. The $>500 \mu \mathrm{m}$ fraction was checked on some occasions and 219 no living foraminifera were found. We consider therefore that in our study area, the results 220 obtained for the $150-500 \mu \mathrm{m}$ size fraction are comparable with those of the $>150 \mu \mathrm{m}$ fraction.

221 Also Bouchet et al. (2012) observed that the number of individuals $>500 \mu \mathrm{m}$ in their samples 222 from the Norwegian Skagerrak coast was minimal. Unfortunately, our foraminiferal analyses 223 were performed prior to the establishment of the methodological recommendations of the 224 FOBIMO group (Schönfeld et al., 2012). The main differences between our methodology and 225 the one described by the FOBIMO group is the use of the $>150 \mu \mathrm{m}$ instead of the $>125 \mu \mathrm{m}$ size 226 fraction, and the absence of replicate cores, which could not be sampled due to time 227 constraints.

229 Rose Bengal stained foraminifera were wet-picked in 50\% ethanol under a binocular 230 microscope (Leica MZ95). Only specimens showing a clear pink colour (or red, depending on 
the species) in all but the last chambers were considered as living fauna. If necessary, opaque

232 porcelaneous and agglutinated specimens were broken to check for the presence of protoplasm. Next, foraminifera were arranged on micropaleontological slides, identified on species level using taxonomic handbooks, and counted.

In order to study the vertical distribution (and microhabitats) of living foraminifera in the sediment, 14 stations have been analysed until at least $4 \mathrm{~cm}$ depth in sediment (station Toulon Grande Rade has only been sampled until $3 \mathrm{~cm}$ ) and a maximum of $10 \mathrm{~cm}$ depth. The faunal parameters from the $0-4 \mathrm{~cm}$ sediment interval have been compared to those obtained for the 0 $1 \mathrm{~cm}$ interval, to determine whether the study of deeper sediment intervals (time-consuming and therefore more expensive) yields important complementary information. An important aim of the present study was to determine whether the study of the $0-1 \mathrm{~cm}$ sediment interval is sufficient to describe the quality of the benthic ecosystem, if so, supporting one of the recommendations of the FOBIMO group (Schönfeld et al., 2012).

\subsection{Foraminiferal parameters}

247 For each station and studied sediment interval (i.e., $0-1 \mathrm{~cm}$ or $0-4 \mathrm{~cm}$ ), we calculated the following faunal parameters: 1) total foraminiferal density (standardised for a $50 \mathrm{~cm}^{2}$ sediment surface), 2) specific richness, and 3) the respective proportion of the three principal foraminiferal groups (perforate, porcelaneous and agglutinated foraminifera). To describe the diversity of the foraminiferal faunas, we used the Shannon-Wiener H index (Hayek and Buzas, 1997) and the Equitability J index (Pielou, 1966) which are defined by the following equations:

where $n_{i}$ is the number of individuals of species $i, N$ is the total number of individuals, and $S$ is the total number of species at the considered station. The Shannon-Wiener index links the number of species to the assemblage density whereas the Equitability index focuses particularly on the distribution of individual densities between the different species (it distinguishes between samples with comparable densities for all species or samples with a dominance of one or a few species). 
263 Because foraminiferal abundances are very different between stations, we also calculated 264 (using PAST software, Hammer and Harper, 2005) the expected number of species from a 265 sub-sample of 50 individuals taken from the population of all the individuals $\left(\mathrm{ES}_{50}\right)$. The 266 concept of expected number of species (ES) was first introduced by Sanders (1968) but its 267 computation was modified by Hurlbert (1971). It is computed as:

$$
E S_{50}=1-\sum_{i=1}^{s} \frac{\left(N-N_{i}\right) !(N-50) !}{\left(N-N_{i}-50\right) ! N !}
$$

where $N$ is the total abundance of individuals at the considered station, $N_{i}$ is the abundance of the $i$ th species at the considered station, and $s$ is the number of species at the considered station. $\mathrm{ES}_{50}$ was not calculated when absolute density was lower than 50 individuals.

After testing the data for normal distribution (Shapiro-Wilk test adapted to small size samples, $\mathrm{n}<50$ ), we used parametric (Student test) or non parametric (Wilcoxon test) statistical analyses for paired samples in order to compare the data obtained for $0-1 \mathrm{~cm}$ and $0-4 \mathrm{~cm}$ sediment intervals. Differences were considered significant when $\mathrm{p}<0.05$.

We also studied the vertical distribution of the various taxa in the first centimetres of sediment. Foraminiferal microhabitats are controlled by physical, chemical and biological 281 processes (Corliss, 1985; Buzas et al., 1993; Jorissen et al., 1995). The microhabitat concept 282 allows a better understanding of the food and oxygen needs of each species. Therefore we calculated the Average Living Depth $\left(\mathrm{ALD}_{\mathrm{x}}\right)$ for the total fauna of the core as follows

284 (Jorissen et al., 1995):

$$
A L D_{x}=\sum_{i=1, x} \frac{\left(n_{i} \times D_{i}\right)}{N}
$$
in which $A L D_{x}$ is the average living depth (in $\mathrm{cm}$ ) of the fauna in a core of $x$ centimetres

288 depth; $n_{i}$ is the number of specimens in the sediment interval $i ; D_{i}$ is the midpoint of the sediment interval $i$ (in $\mathrm{cm}$ ); and $N$ is the total number of individuals for all levels. 


\subsection{Environmental parameters}

292 Pore water oxygen profiles were measured on board under in situ temperature conditions using a cathode-type mini-electrode (100 or $500 \mu \mathrm{m}$ tips, Unisense $C$ ) (Revsbech 1983; Helder and Bakker 1985; Revsbech and Jørgensen 1986) for Reineck cores with a well preserved sediment water interface with overlying bottom waters. These analyses were generally duplicated and allowed to determine the maximum oxygen penetration depth (OPD) in the

297 sediment.

During the oceanographic cruise, in addition to sediment for foraminiferal analysis, sediment was also sampled for grain size and total organic matter analyses. Grain size analysis was conducted using a Malvern ${ }^{\circledR}$ Mastersizer 2000 laser microgranulometer. Organic matter content corresponds to ash free dry weight. Weight-loss after combustion $\left(450^{\circ} \mathrm{C}, 5 \mathrm{H}\right)$ of lyophilised samples is measured.

\section{Results}

\subsection{Sediment characteristics}

The large difference in the continental shelf features between the eastern and western French Mediterranean coast has an important impact on the sediment characteristics observed at our sampling stations.

311 The 31 stations sampled have been chosen according to the Water Framework Directive

312 strategy, and are systematically positioned within 1 mile from the coast line. Because of this

313 sampling policy and the heterogeneity of the French Mediterranean coast, there is a clear

314 difference in the average water depth of the stations from the western part of our study area

315 (18m on average) compared to those from the east (40m on average). The limit between the

316 two areas is approximately positioned between the stations Fos and Carry (Figure 2a,

317 Appendix B).

319 The grain size analyses show a clear difference between western and eastern stations (Figure 320 2c-d-e, Appendix B). Stations west of Carry contain a low proportion of sand $>250 \mu \mathrm{m}$, with 321 the exception of the stations Collioure and Cerbère, which are located at the most western part 322 of the French coast. Conversely, the eastern stations show a high proportion of medium (250- 
$500 \mu \mathrm{m})$ and coarse $(500-1000 \mu \mathrm{m})$ sands, with the exception of some stations (e.g. Marseille Jetée, Ile Embiez, Nice, Menton). There is a significant positive correlation between the percentage of the $>500 \mu \mathrm{m}$ fraction and water depth $(\mathrm{r}=0.50, \mathrm{p}<0.05$; Appendix $\mathrm{C})$, which underlines the difference in sediment characteristics along the French Mediterranean coast. Conversely, stations located close to the Rhône river mouth (Fos, Carteau, Beauduc) show a high proportion of clay and silt particles $(<63 \mu \mathrm{m})$, in response to a continuous input of finegrained sediment from the Rhône river.

The organic matter content (Figure 2b, Appendix B) has been analysed on the total sediment, without any pre-treatment. Consequently, this organic matter is not only composed of marine phytoplankton detritus and of river-supplied continental organic matter, but also by much larger debris of macro-algae and seagrass (roots, leaves). The feeding strategies of foraminifera are various, from detritivory on labile or also more refractory organic matter, to carnivory and bactivory (review in Murray et al. 2006). In our study area, marine and continental sedimentary organic matter can probably serve as food for the benthic foraminifera, which is probably not the case for the seagrass debris. In fact, the trophic state of marine sediments is not only dependent on the absolute quantities of organic matter deposited on the sea floor, but it is also a function of its biochemical composition and nutritional quality for consumers (Pusceddu et al., 2009). Several studies (e.g. Mateo et al., 2006; Østergaard Pedersen et al., 2011) have shown that the roots, rhizomes, and leaf sheaths of Posidonia decompose very slowly due to their high content of lignin, cellulose, and phenolic compounds (Harrison, 1989; Klap et al., 2000), which are not readily degraded by microbes (Godshalk and Wetzel, 1978). Therefore the large amounts of Posidonia leaves and roots found at several stations in our study area, resulting in very high OM values in some stations, cannot be considered as readily available food for benthic organisms. Consequently, it appears impossible to use the OM percentages as measure of the trophic level or as an indicator of anthropogenic pressure. There is no clear west-east trend in the OM percentage (Figure $2 b$ ), but there is a statistically significant positive correlation between the OM content and the percentage of clay/silt $(<63 \mu \mathrm{m})$ particles $(\mathrm{r}=0.42, \mathrm{p}<0.05$; Appendix $\mathrm{C})$, as was observed previously in other coastal areas (e.g. Jorissen, 1987, 1988; Fontanier et al., 2008). Large quantities of macro-algae and seagrasses (e.g. detritus of Posidonia roots) observed in the sediment collected at stations east of Fos explain the abnormally high OM percentages found in some stations with coarse sediments (e.g. Ile Maire, Porquerolles, Ile Levant). 
356 Summarising, natural environmental characteristics appear to be very different between the

357 western stations (lower water depth, fine sediment, enriched in sedimentary organic matter)

358 and the eastern stations (higher water depth, coarser sediment, and sometimes abundant plant

359 remains) in our study area. The faunal assemblages that are colonising these different types of

360 environments will therefore be very different naturally. This bias will have to be taken into

361 account when trying to construct a bio-indicator method based on the foraminiferal faunas.

362 However, it is very probable that this strong west-east dichotomy will equally affect the

363 macrofaunal distribution.

\subsection{Diversity and density of the living fauna}

366 Living foraminiferal densities standardised for $50 \mathrm{~cm}^{2}$ are highly variable among stations

367 (Figure 3a, Appendix B). For the $0-1 \mathrm{~cm}$ sediment interval (31 stations considered), the total

368 number of foraminifera varies between 22 specimens $/ 50 \mathrm{~cm}^{2}$ for station Faraman and 2091

369 specimens $/ 50 \mathrm{~cm}^{2}$ for station Grau du Roi. For the $0-4 \mathrm{~cm}$ sediment interval (14 stations

370 considered), total densities vary between 387 and 2526 specimens $/ 50 \mathrm{~cm}^{2}$ for stations Ile

371 Maire and Grau du Roi, respectively. The very low densities found at stations Faraman,

372 Lavandou and Porquerolles (22, 43 and 51 specimens $/ 50 \mathrm{~cm}^{2}$, respectively) could result from

373 the loss of a large part of the superficial sediment before the Reineck core reached the deck of

374 the ship.

375 The stations Leucate, Villefranche and Menton exhibit a particularly strong difference in

376 densities between both studied sediment intervals (0-1 and 0-4cm), indicating the presence of

377 abundant live foraminiferal faunas in deeper sediment layers. In most other stations, this

378 difference is smaller.

379 Diversity indices are relatively high at all studied stations (Appendix B). Species richness in 380 the first centimetre of sediment varies between 20 (station Agde Est) and 73 species (station

381 Monaco) (Figure 3b). The Shannon-Wiener index (Figure 3c) varies between 1.9 (station

382 Grau du Roi) and 3.7 (station Monaco). The Equitability index (Figure 3d), which gives

383 information about the dominance of one or more taxa, varies between 0.53 (station Grau du

384 Roi) and 0.96 (station Marseille Grande Rade). According to these indices, biodiversity seems

385 to increase to the eastern part of the French Mediterranean coast, where the depth of the

386 sampling stations is more important. There is indeed a statistically significant positive

387 correlation between the diversity indices and water depth ( $\mathrm{r}=0.79$ for $\mathrm{ES}_{50}, \mathrm{r}=0.74$ for 
Shannon-Wiener index, $\mathrm{r}=0.66$ for specific richness, and $\mathrm{r}=0.52$ for Equitability index, $\mathrm{p}<0.05$ for all correlations; Appendix C).

The expected number of species from a sub-sample of 50 individuals $\left(\mathrm{ES}_{50}\right.$, Figure $\left.3 \mathrm{e}\right)$ exhibits smaller differences between stations compared to uncorrected species richness. In general, stations with relatively low total faunal densities (e.g. Cerbère, Marseille Grande Rade or Porquerolles) deviate less from the overall trend. This observation confirms the good performance of the $\mathrm{ES}_{50}$ index in case of samples with large differences in faunal density, which is also the case for the Shannon-Wiener and Equitability indices.

The comparison of the diversity indices for the $0-1 \mathrm{~cm}$ and $0-4 \mathrm{~cm}$ intervals shows first that on average 8 additional species (a maximum of 16 species), have been found when the $1-4 \mathrm{~cm}$ interval is added (Figure $3 \mathrm{~b}$ ). However, the difference in Shannon-Wiener and $\mathrm{ES}_{50}$ indices between the 2 considered depth intervals is relatively small (Figure $3 \mathrm{c}$ and $3 \mathrm{~d}$ ). Species exclusively found in the 1 to $4 \mathrm{~cm}$ sediment interval are represented by few specimens; the density differences between the $0-1$ and $0-4 \mathrm{~cm}$ levels highlighted in Figure $3 \mathrm{a}$ are mainly resulting from an increase in the density of species that also occur in the first centimetre of the sediment. The statistical comparison of the diversity indices of both intervals shows a significant difference for the specific richness $(\mathrm{t}=-7.05, \mathrm{p}=0.000)$ and Shannon index $(\mathrm{t}=-2.71$, $\mathrm{p}=0.02)$, but no significant differences for the Equitability index $(\mathrm{t}=1.53, \mathrm{p}=0.15)$ and $\mathrm{ES}_{50}$ $(\mathrm{t}=-1.12, \mathrm{p}=0.28)$.

\subsection{Vertical distribution of total living foraminiferal faunas}

Oxygen profiles have been measured at 11 stations. In fact, overlying water, essential for oxygen profiles, was not always available when we used a Reineck corer. A typical example of an oxygen profile obtained at station Carteau is shown in Appendix D. Oxygen saturation is $93 \%$ in the bottom waters and starts to decrease at the sediment-water interface. The oxygen concentration in the interstitial waters decreases rapidly within the first millimetres of the sediment to reach anoxic conditions at $6 \mathrm{~mm}$.

The vertical distribution of living foraminifera is controlled by the oxygen penetration depth in the sediment, the grain size, the availability of labile organic matter and by macrofaunal bioturbation, the latter parameter modifying the former three (e.g. Corliss, 1985; Shirayama, 1984; Corliss and Emerson, 1990). 
422 The vertical distribution of foraminiferal faunas was studied at 14 stations. In order to group 423 these 14 stations in function of sediment grain size, we performed a cluster analysis (using the

424 Ward method) using the different measured grain size fractions (percentages of particles $425<63 \mu \mathrm{m}, 63-125 \mu \mathrm{m}, 125-250 \mu \mathrm{m}, 250-500 \mu \mathrm{m}$ and $>500 \mu \mathrm{m})$. As a result, we obtained two 426 groups of stations: group A with muddy to silty sediments, and group B with sandy 427 sediments. In table 1 , it can be seen that the average living depth $\left(\mathrm{ALD}_{5} / \mathrm{ALD}_{6}\right)$ of the live 428 foraminiferal fauna is considerably higher for the sandy stations (group B) than for the 429 clayey-silty stations (group A) (Figures 4 and 5).

431 For the stations of group A, with clayey-silty sediment (Figure 4), faunas present a maximum 432 density in the first centimetre of the sediment (often in the first half centimetre) followed by a 433 noticeable decrease downcore, more or less sharp. Group A stations are characterised by a 434 relatively shallow average living depth $\left(\mathrm{ALD}_{5} / \mathrm{ALD}_{6}\right)$, from 1.0 to $1.6 \mathrm{~cm}$ (Table 1$)$. These 435 stations have a relatively high OM content, between 1.68 and $7.52 \%$ (4.34\% on average). 436 There is a strong negative correlation between the $<63 \mu \mathrm{m}$ particle size fraction and the ALD $_{\mathrm{x}}$ 437 of the total fauna $(\mathrm{r}=-0.57, \mathrm{p}<0.03)$. Generally, silty-clayed marine environments are 438 characterised by weak hydrodynamics allowing the deposition of organic matter (Tyson, 439 1995) and its adsorption on clay particles (Hedge and Keil, 1995). Fine grained substrates can 440 therefore often be considered as eutrophic to mesotrophic environments.

441 The strong surface maximum, together with poor faunas in deeper sediment layers found at 442 these stations is typical for eutrophic environments with limited oxygen penetration depth (a 443 maximum OPD of $14 \mathrm{~mm}$ for stations where oxygen profiles were performed) (Jorissen et al., 444 1995).

Also for the stations of group B (Figure 5), the foraminiferal vertical distribution is generally characterised by a density maximum in the first centimetre of sediment. However, unlike group A, densities remain high in deeper sediment layers. Consequently, the $\mathrm{ALD}_{5} / \mathrm{ALD}_{6}$ of these stations is much higher (between 1.4 and $2.7 \mathrm{~cm}, 2.1 \mathrm{~cm}$ on average; Table 1).

450 For some stations (e.g. Agde Est, Leucate), the faunal density and composition are almost the 451 same in every sediment layer down to $5 \mathrm{~cm}$. The stations of group B are generally 452 characterised by a lower OM, of $2.5 \%$ on average (1.37-3.99\%).

453 Unfortunately, no oxygen measurements could be performed for the stations of group B.

454 However, the abundant faunas in deeper sediment layers suggest that oxygen penetration is 
considerably deeper here than at the stations of group A, where oxygen penetration varies from 6 to $14 \mathrm{~mm}$ (Table 1).

\subsection{Species composition of living foraminiferal faunas}

In total, 40 major species ( $>5 \%$ in at least one station, $150-500 \mu \mathrm{m}$ ) have been identified: 20 perforate, 8 porcelaneous and 12 agglutinated taxa (Table 2, see Plates 1-2-3-4 in Supplementary material 1 , Supplementary material 2 for standardised counting data and Supplementary material 3 for the taxonomical list of major species).

The relative densities of these major species do not show a statistically significant difference between the $0-1$ and $0-4 \mathrm{~cm}$ levels (Appendix E). This result indicates that the percentages of the dominant taxa of the first centimetre can be considered as representative for the whole fauna. The following discussion is therefore uniquely based on the $0-1 \mathrm{~cm}$ level.

Among the 40 major species, 10 are very common in the study area, and are present in more than $70 \%$ of the stations: 2 perforate taxa (Ammonia beccarii, Buccella granulata), 4 porcelaneous taxa (Adelosina longirostra, Quinqueloculina aspera, Q. seminula, Triloculina trigonula) and 4 agglutinated taxa (Eggerella scabra, Lagenammina spp., Reophax fusiformis, Textularia agglutinans). More specifically, Eggerella scabra is clearly the most common species since it is present in 26 of the 31 stations; 15 stations with relative densities over $5 \%$ and 7 stations where it represents more than $30 \%$ of the total fauna.

On the contrary, some stations are characterised by a strong relative abundance of species that are not frequently found at other stations. For example, Elphidium crispum is dominant at the station Grau du Roi where it represents 54.6\% (1142 specimens per 50 $\mathrm{cm}^{2}$ ). This species shows only very low abundances (less than 15 specimens) in 13 other stations and is absent in the rest of the stations. Station Leucate presents also a peculiar faunal composition compared to other studied stations with high relative densities of Nonion depressulum (18.4\%) and Nonionella turgida (16.1\%), these species being very scarce in other locations except at Grau $\mathrm{du}$ Roi. Leucate is also characterised by a relative abundance of $6.7 \%$ of Leptohalysis scotti, which appears only with single individuals in 3 other stations.

The analysis of the correlations between the available environmental data and the relative densities of the major species is given in Appendix F. Since our study concerns a very large area with strongly contrasting environmental characteristics, it may be expected that also the 
488

489

490

491

492

493

494

495

496

497

498

499

500

501

502

503

504

505

506

507

508

509

510

faunal composition will show large differences between stations. For example, the positive correlation of Nonion depressulum and Nonionella turgida with the $63-125 \mu \mathrm{m}$ grain size fraction is mainly determined by their high percentages at station Leucate, which is characterised by $53 \%$ of very fine sand $(63-125 \mu \mathrm{m})$. At other stations with similar sediment grain size (e.g. Ile Embiez, Agde Ouest), these taxa are much less frequent or absent.

Consequently, it becomes difficult to work with individual (marker) species and to observe clear relations between single species percentages and environmental parameters. It is therefore more relevant to define groups of species with a similar distribution, which will respond in the same way to the environmental parameters.

Several trials with Q- and R-mode multivariate statistics (Principal Component Analysis, cluster analysis) to construct species clusters only yielded very inconclusive results. Q-mode PCA results show that Elphidium crispum and Eggerella scabra are responsible for most of the variability in the dataset when considering the two first PCA axes (see Supplementary material 4). This is due to the strong dominance of E. crispum at station Grau du Roi and the high relative densities of E. scabra at a number of stations. These species also stand out in the R-mode PCA. The other species cluster together, and do not form clear species groups, even not when considering the next axes. Faunal clusters systematically contain a mix of species with different ecological characteristics, and were therefore very difficult to interpret ecologically (see Supplementary material 5). For this reason, we preferred to test three a priori groupings, based on 1) wall structure, 2) life position (epiphytic species), and 3) literature observations on tolerance/sensitivity with respect to eutrophication.

\subsection{Species groups indicative of environmental quality}

According to the comparison between $0-1 \mathrm{~cm}$ and $0-4 \mathrm{~cm}$ sediment intervals for density, diversity and species composition (see paragraph 5.1 for more details), we considered only data from the first centimetre of the sediment for the study of groups of indicative species of environmental quality.

\subsubsection{Species groups according to wall structure}

A ternary diagram (Figure 6, after Murray, 1973) presents the contribution of the 3 main groups (defined by wall structure) to the foraminiferal faunas (of the $0-1 \mathrm{~cm}$ level): perforate, 
porcelaneous and agglutinated species (see also Appendix B). Station Collioure is the only 521 one showing a majority of porcelaneous taxa (Figure 6, upper blue triangle). The faunas of stations Toulon Grande Rade, Marseille Grande Rade, Ile Plane, Porquerolles, Marseille Jetée, Carry, Fos and Grau du Roi are composed in majority of perforate foraminifera (Figure 6, lower right red triangle) whereas stations Nice, Agde Est and Ouest, Gruissan, Sète and Ile Embiez are characterised by a dominance of agglutinated tests (between 54 and 71\%; Figure 6, lower left green triangle). At station Beauduc, where porcelaneous taxa are almost absent, equal amounts of perforate and agglutinated taxa are found. The remaining stations don ${ }^{\text {ee }} \mathrm{t}$ show a clear dominance of one of the groups.

We performed a canonical correspondence analysis to compare the available environmental parameters (grain size fractions, OM content and water depth) with the percentage of the three wall structure groups. The result shows that the five distinguished grain size fractions are distributed in a horse shoe pattern (Figure 7). The percentage of porcelaneous taxa is plotted in the same area as medium sand $(250-500 \mu \mathrm{m})$, and is opposed to the percentages of clay and silt. In fact, there is a significant positive correlation between the percentage of porcelaneous taxa and the fine and medium sand fractions (for $125-250 \mu \mathrm{m}, \mathrm{r}=0.57, \mathrm{p}<0.05$; for $250-500 \mu \mathrm{m}$, $\mathrm{r}=0.55, \mathrm{p}<0.05)$ and a negative correlation with the clay/silt fraction $(\mathrm{r}=-0.71, \mathrm{p}<0.05$; Appendix C). The percentage of perforate foraminifera plots in the same area as OM content and water depth; there is indeed a positive correlation between their percentage and the percentage of clay/silt $(r=0.42, p<0.05)$ and with the $\mathrm{OM}$ content $(\mathrm{r}=0.50, \mathrm{p}<0.05$; Appendix C). Finally, the percentage of agglutinated taxa plots together with the $63-125 \mu \mathrm{m}$ fraction showing a positive correlation $(\mathrm{r}=0.47, \mathrm{p}<0.05)$. This group anti-correlates with coarse sand $(>500 \mu \mathrm{m}, \mathrm{r}=-0.52, \mathrm{p}<0.05)$. In general, the distribution of this group seems to be opposite to the one of the perforate taxa $(r=-0.74, p<0.05$; Appendix $C)$.

\subsubsection{Species group according to life position (epiphytic species)}

547 To constitute the epiphytic species group (i.e. capable to live fixed on algae), we selected the species classified in morphotypes A and B as defined by Langer (1993). These morphotypes have been defined according to the different modes of surface attachment and the feeding strategies. Morphotype A represents stationary, permanently attached species which secrete an organic substance to glue to seagrass leaves or algal blades (e.g. Planorbulina mediterranensis). Morphotype B represents temporary attached species which have a 
553 trochospiral shape with apertures facing the substrate (e.g. Rosalina globularis). Morphotypes

$554 \mathrm{C}$ and D are not considered in our group of epiphytic species since they can also live in areas

555 without seagrass or algae considering their permanently motile behaviour (e.g. elphidiids,

556 porcelaneous species). The epiphytic species identified in our samples are Asterigerinata

557 mamilla, Cibicides lobatulus, Gavelinopsis praegeri, Hanzawaia boueana, Neoconorbina

558 terquemi, Planorbulina mediterranensis, Rosalina bradyi, R. globularis, Rosalina

559 vilardeboana and other Rosalina species (e.g. Jorissen, 1987; Kitazato, 1988; Langer, 1993;

560 Barmawidjadja et al., 1995; Schönfeld, 2002; Murray, 2006; Buosi et al., 2012). These

561 epiphytic species are indicative of the presence of vegetation in the vicinity of the sampling

562 station and generally of a good ventilation of bottom waters. According to Van der Zwaan et

563 al. (1999), many epiphytic species are sensitive to oxygen-limited conditions and would be

564 competitive in oligotrophic environments. They are mainly found in sandy sediments (Pujos,

565 1976; Spindler, 1980; Bizon and Bizon, 1984; Jorissen, 1987; Murray, 1991; Villanueva

566 Guimerans and Cervera Currado, 1999; Mendes et al., 2004; Mojtahid et al., 2006) and some

567 of these species, such as Cibicides lobatulus and Gavelinopsis praegeri, can tolerate high

568 energy environments (Coppa and Di Tuoro, 1995; Guimerans and Currado, 1999; Schönfeld,

569 2002; Panieri et al., 2005; Martins et al., 2007; Milker et al., 2009). In our study area, the

570 Posidonia meadows provide abundant niches for these foraminiferal species; the rhizomes act

571 as sediment traps and the leaves are often colonised by motile or (temporarily) fixed epiphytic

572 foraminifera (Vénec-Peyré, 1984; Langer, 1993).

573

574 We calculated the cumulative percentage of epiphytic species for the $0-1 \mathrm{~cm}$ interval of the 31

575 studied stations (Figure 8a, Appendix B). Figure 8a highlights again the clear difference

576 between western shallow stations and eastern deeper stations (limit between Fos and Carry),

577 with the exception of Antibes Nord and Nice were epiphytic species are absent. As illustrated

578 by the CCA analysis (Figure 9), there is a positive correlation between the percentage of

579 epiphytic species and water depth $(\mathrm{r}=0.53, \mathrm{p}<0.05)$, medium and coarse sediment (for 250 -

$580500 \mu \mathrm{m}, \mathrm{r}=0.40, \mathrm{p}<0.05$; for $>500 \mu \mathrm{m}, \mathrm{r}=0.80, \mathrm{p}<0.05)$. On the other side, there is a negative

581 correlation with fine sands $(63-125 \mu \mathrm{m} ; \mathrm{r}=-0.50, \mathrm{p}<0.05$; Appendix $\mathrm{C})$. 


\subsubsection{Species groups according to tolerance/sensitivity to organic enrichment}

According to the literature, we defined two species groups: 1) a group of "stress-tolerant" species, with a high percentage being indicative of stressed conditions, such as eutrophication or abundant supplies of fine-grained sediments, and 2) a group of sensitive species, which are supposed to be indicative of a good overall quality of the ecosystem, and which should disappear when environmental conditions become more stressful.

Ten stress-tolerant taxa were identified on the basis of literature evidence: Bulimina spp., Cancris auriculus, Nonion scaphum, Nonion depressulum, Nonionella turgida, Nonionella stella, Pseudoeponides falsobeccarii, Rectuvigerina phlegeri, Valvulineria bradyana and the agglutinated Leptohalysis scotti (see Plate 2 in Supplementary material 1). The observations presented in the literature which supported our decision to place these 10 taxa in the tolerant group are listed in Appendix G.

The group of sensitive species (see Plate 3 and 4 in Supplementary material 1) includes all porcelaneous species and all epiphytic species. In addition, we also included other motile epiphytic species (morphotypes C and D according to Langer, 1993) such as Elphidium species (Elphidium crispum, E. granosum and E. poeyanum), Reussella spinulosa and Spirillina spp.. According to the literature that supports our choice to group all these species sensitive to stressed conditions (see Appendix G for literature references on which this grouping was based), a poor representation of this group in the total fauna would be indicative of enrichment in muddy sediments, eventually leading to low oxygen conditions.

Among the 40 major species identified, 14 species have not been assigned to one of these two groups, either because they are neither sensitive nor stress-tolerant, or due to a lack of well documented studies with clear pollution gradients, or due to contradictory literature data with respect to their ecological characteristics.

The case of Eggerella scabra is particularly striking. Although this species has been reported in several articles as being able to tolerate stressed conditions, we did not include it in the group of tolerant species. Eggerella scabra is a continental shelf species (e.g. Murray, 1991; Barmawidjaja et al., 1992) that lives in muddy to sandy substrates (Murray, 1986; Alve and Nagy, 1986; Scott et al. 2003) and in various microhabitats, from the oxygenated sediment 
616 surface to the deepest anoxic layers (e.g. Barmawidjaja et al., 1992; Jorissen et al., 1992;

617 Ernst et al., 2002, 2005; Duijnstee et al., 2003, 2004). It appears therefore to be tolerant for

618 hypoxic conditions. For instance, E. scabra is common in the Adriatic Sea, in areas where

619 important amounts of degraded organic matter cause oxygen depletion (Donnici and

620 Serandrei-Barbero, 2002). It has also been shown to support extremely polluted environments

621 in Sorfjord, western Norway (Alve, 1991). On the other hand, this species is very common

622 and typical in many apparently unpolluted coastal Mediterranean environments (e.g. Venec-

623 Peyré, 1984; Donnici and Serandrei-Barbero, 2002; Duijnstee et al., 2003; Frontalini and

624 Coccioni, 2008; Mojtahid et al., 2009; Goineau et al., 2012; Sabbatini et al., 2010, 2012).

625 Several authors suggested that this species has a poorer tolerance to stressed conditions than

626 some clear opportunists, although it has a great ability to withstand fluctuations in diverse

627 parameters including an absence of labile organic matter (Scott et al., 2003; Mojtahid et al.,

628 2007; De Nooijer et al., 2008; Sabbatini et al. 2012). Finally, some authors have considered $E$.

629 scabra as an epiphytic species on seagrass (Redois et Debenay, 1996; Debenay, 2000), again

630 suggesting that it can be a dominant faunal element in high quality ecosystems. Because of

631 this strongly contrasting evidence and the high densities of E. scabra in most of our studied

632 stations, we decided not to include this species in our stress-tolerant group so that it does not

633 obscure the message given by more clear stress-tolerant species.

634

635 Figure 8b-c show the percentages of sensitive and stress-tolerant species in our study area

636 following a West-East transect. In our dataset, the percentage of stress-tolerant species

637 positively correlates with the percentage of fine particles $(r=0.48, p<0.05)$ and organic matter

$638(\mathrm{r}=0.40, \mathrm{p}<0.05$; Figure 9 and Appendix C $)$. Conversely, stress-tolerant species are weakly

639 represented in eastern stations, in spite of high organic matter contents measured at some

640 stations (e.g. stations Fréjus and Antibes).

641 Conversely, sensitive species are negatively correlated with the percentage of fine particles

642 (for $<63 \mu \mathrm{m}, \mathrm{r}=-0.49, \mathrm{p}<0.05$; for $63-125 \mu \mathrm{m}, \mathrm{r}=-0.44, \mathrm{p}<0.05$ ) and positively correlated with

643 coarser particles (for $250-500 \mu \mathrm{m}, \mathrm{r}=0.59$, $\mathrm{p}<0.05$; for $>500 \mu \mathrm{m}, \mathrm{r}=0.60, \mathrm{p}<0.05$; Figure 9 and

644 Appendix C).

645 


\section{Discussion}

647

648

649

650

651

652

653

654

655

656

657

658

659

660

661

662

663

664

665

666

667

668

669

670

671

672

673

674

675 677

676 To know if a study restricted to the first centimetre of sediment (generally containing the

\subsection{Representativity of the fauna of the first centimetre of sediment}

Ecological studies of recent foraminiferal faunas are usually based on the analyses of the total fauna in the sediment column, down to 5 or $10 \mathrm{~cm}$ depth. In fact, the vertical distribution of foraminifera can give information about the ecological strategies of different species or about the environmental conditions. In our study, the fauna of deeper sediment layers allows us to distinguish two types of environments. More eutrophic, silty/clayey stations with a limited oxygen penetration depth have the large majority of the fauna in the topmost centimetre, whereas sandy stations, probably with lower organic matter supplies, show a more even faunal distribution in the first 2 to $5 \mathrm{~cm}$ of the sediment.

Although this environmental information is not without interest, the significantly longer picking time required to obtain data from deeper layer makes that the study of the vertical distribution analysis is hardly possible for bio-monitoring studies, in which economical aspects are important, and strict deadlines have often to be respected. Recently, the FOBIMO group recommended therefore to limit foraminiferal bio-monitoring studies to the analysis of the first centimetre of the sediment. This recommendation was supported by the results of Bouchet et al. (2012), who studied the faunal response to various oxygen concentrations in the Norwegian Skagerrak, using diversity indices based on the faunas in the $0-1 \mathrm{~cm}$ and $0-2 \mathrm{~cm}$ intervals. It turned out that the results were virtually similar, suggesting that the study of the $0-1 \mathrm{~cm}$ was sufficient.

However, before taking the decision to restrict the faunal analysis to the uppermost centimetre, we wanted to verify whether this does not lead to an erroneous or incomplete interpretation of the faunal response to environmental conditions when considering our coastal Mediterranean samples. In our study area, species living exclusively in deeper sediment layers (e.g. Corliss, 1985; Jorissen, 1995) were not observed (Figure 4-5). Buzas et al. (1993) highlighted the fact that the microhabitat succession usually observed in deep water (outer continental shelf and slope) is much less evident on inner continental shelf environments. They explained this difference by the more dynamic nature of coastal areas (sediment disturbance, bioturbation, etc.). majority of the living fauna) is sufficient to correctly define the environmental quality, we 
compared faunal parameters between $0-1$ and $0-4 \mathrm{~cm}$ intervals. Statistical comparison of Equitability indices and $\mathrm{ES}_{50}$ show no significant difference between $0-1$ and $0-4 \mathrm{~cm}$.

However, faunal densities are significantly different. For the Shannon index, the statistical test identified significantly higher values for the $0-4 \mathrm{~cm}$ interval (test based on the sign of the difference). However, the differences are small (average shift between the values from 0-1 and $0-4 \mathrm{~cm}$ intervals of 0.11 ), and would not cause major changes in the classification of the stations into the different quality categories. It is also interesting to observe that there are no significant differences in the relative densities of major species which change only slightly between the 0-1 and 0-4cm intervals (Wilcoxon test, Appendix E).

In view of all these results, we conclude that in our study area, the first centimetre of the sediment gives a very good picture of the overall live fauna, its diversity and composition. Therefore, our results fully support the recommendation of the FOBIMO group (Schönfeld et al., 2012).

\subsection{Relevance of the various faunal parameters for ecosystem quality evaluation}

Ideally, the development of a faunal index of environmental quality should be based on a precise knowledge of pollution sources and intensities in the study area. The analysis of faunal patterns along a well-described pollution gradient makes it possible to distinguish species with various degrees of tolerance, and to identify the faunal parameter(s) or indices that correlate best with the state of the environment, as defined by the concentration of one or more pollutants. Usually, such studies focus on the impact of a single stress parameter on the foraminiferal faunas, such as bottom water oxygen concentration (Bouchet et al., 2012), eutrophication (Mojtahid et al., 2008), or chemical pollution (Frontalini and Coccioni, 2008; Mojtahid et al., 2006). In our study, the geographical area of concern is very wide, pollutants are dispersed in an erratic way, and their concentration is not known. Consequently, we do not dispose of a clear transect following a pollution gradient, and our approach has therefore to be slightly different. We cannot have the ambition to directly develop a biotic index, but instead, we will try to determine which faunal parameters could be relevant to adequately describe the ecosystem health. 


\subsubsection{Biodiversity indices}

According to different diversity indices calculated, biodiversity seems to be higher at the eastern part of the French Mediterranean coast. Unfortunately, because of the strong positive correlation between diversity indices and water depth, it is impossible to say whether the higher values of the diversity indices of the eastern stations indicate a higher overall biodiversity, or whether they are the result of a sampling bias (shift in water depth). Diversity indices give important information about biodiversity and faunal equilibrium at a station. It has been shown that biodiversity indices may be useful to classify the ecosystem quality in strongly polluted conditions (e.g. Bouchet et al., 2012; Armynot du Chatelet et al., 2004). Our study area differs from the severely stressed environments described by these authors, because of the absence of a clear stress parameter, such as oxygen depletion or heavy metal pollution. In fact, the French Mediterranean coast is generally considered as rather oligotrophic (e.g. Bosc et al., 2004). Consequently, a slight eutrophisation of the benthic ecosystem does not necessarily lead to a decreased biodiversity, but could easily cause an increase of the values of diversity indices. Based on several studies of macrofauna along a gradient of organic enrichment, the Pearson-Rosenberg model (also called SAB model, Pearson and Rosenberg, 1978) clearly shows that a slight increase in organic matter content leads first to an increase of the number of species. Several earlier studies show that foraminiferal diversity is decreasing along bathymetric transects in response to lowering of the OM flux towards greater water depth (e.g. Rathburn et al., 1996; Schmiedl et al., 2000;

730 Fontanier et al., 2008). Consequently, we think that in the oligotrophic Mediterranean sea,

731 diversity indices are not an appropriate tool to describe the environmental quality of benthic 732 ecosystems.

\subsubsection{Species groups according to wall structure}

According to our data (Figure 7, Appendix C) and the literature, porcelaneous taxa have the clearest ecological response to environmental change. They are found abundantly in coarsegrained shallow water environments with a low OM content and oxygen-saturated bottom waters (e.g. Jorissen, 1988; Donnici and Serandrei-Barbero, 2002). Bizon and Bizon (1984) observed that this group is also abundant in sandy sediments on the continental shelf off the Rhône River. In our study, their percentage shows a clear decrease with an increasing percentage of fine sediment ( $<63 \mu \mathrm{m}$; Figure 7 and Appendix C). Therefore, samples with a 
742 high percentage of porcelaneous taxa should denote stations with rather good environmental

743 quality, whereas the opposite should be true for samples with very low percentages of

744 porcelaneous taxa. For example, stations Collioure, Fréjus and Cap Canaille all show more

745 than $40 \%$ of porcelaneous taxa, suggesting healthy environmental conditions. Conversely,

746 stations Grau du Roi, Fos, Carry and Marseille Jetée show very low percentages of

747 porcelaneous specimens (less than $8 \%$ ), and very high percentages of perforate foraminifera

748 (over 60\%) (Figure 6), suggesting that these stations with clayey-silty sediments may be

749 characterised by a slightly degraded ecological state. However, we cannot push the

750 interpretation much further. In fact, wall structure groups present the disadvantage to separate

751 species according to morphological criteria, which do not necessarily correspond exactly to

752 ecological preferences and tolerances (Buzas et al., 1993). When we look in more detail at the

753 species composing the three groups, it appears that some important species do not at all

754 respect the general tendency. For example, some porcelaneous species have been observed to

755 behave as opportunistic species in particular conditions. So has Quinqueloculina seminula

756 been described as an early foraminiferal recoloniser of the benthic ecosystem after a gravity

757 flow in the Whittard canyon (Duros et al., 2011) and on an ash layer deposit around Mt.

758 Pinatubo in the South China Sea (Hess and Kuhnt, 1996). Another example is the group of

759 perforate species which includes species that we classified as tolerant to stressed conditions

760 (e.g. Nonion scaphum, Cancris auriculus) and epiphytic species which are generally

761 considered as very sensitive to eutrophication.

763 Summarising, an index based on the cumulative percentages of the three wall structure groups

764 can give a rapid first overall characterisation of the state of the environment, but may in some

765 specific cases lead to erroneous conclusions. It appears therefore that it is more judicious to

766 base a biotic index on groups of indicator taxa which have a similar response to stressed

767 conditions.

\section{4.2.3 Species groups according to life position (epiphytic species)}

770 Our data seem to confirm the literature: epiphytic species are most successful on coarse-

771 grained substrates (Figure 9, Appendix C), where bottom waters are normally well

772 oxygenated. The rather surprising positive correlation with OM content (Appendix C) is

773 probably caused by the presence of abundant larger plant debris in seagrass meadows, leading

774 to anomalously high OM values. High percentages of epiphytes are found in eastern part of 
the French Mediterranean coast as well as in front of Banyuls-sur-Mer, where Posidonia meadows are growing (Gobert et al., 2009). Since Posidonia meadows are known to be highly sensitive to human disturbance (Boudouresque et al., 2000, 2006), our observations suggest that high percentages of epiphytic species could indeed be indicative of a good ecosystem quality. However, their absence at stations naturally characterised by more fine-grained substrates and lack of vegetation cover cannot be interpreted as indicative of a bad ecosystem state. It appears therefore that this parameter can emphasize a very good ecosystem state in some cases, but cannot be used to characterise the environmental quality along the entire French Mediterranean coast.

\subsubsection{Species groups according to tolerance/sensitivity to organic enrichment}

Figure $8 \mathrm{c}$ shows a clear increase in the percentage of stress-tolerant species in the stations located around the Rhône River mouth. The Rhône River is the main sediment source in the Gulf of Lions (80\%; Durrieu de Madron et al., 2000). Hence, stations located in the vicinity of the delta are influenced by supplies of fine sediment and terrestrial organic matter. However, these stress-tolerant species do not occur in all stations exhibiting high percentages of OM because in several eastern stations these high values reflect the presence of macro-algae detritus, as mentioned earlier.

Sensitive species are less adapted to inhabit muddy to silty substrates which are often characterised by a varying degree of organic enrichment. This enrichment can be entirely natural, or partly, in some cases even entirely anthropogenic. Therefore, a historical disappearance of sensitive species (shown by a comparison of recent and fossil faunas) can highlight either a (natural) shift from more sandy to more muddy sediment, or an increase of anthropogenic organic supplies.

Summarising, the proportions of stress-tolerant and sensitive species can allow us to distinguish two kinds of environments:

1) Faunas characterised by a high percentage of stress-tolerant species and a low percentage of sensitive species are indicative of fine-grained substrates often associated with high organic matter contents. This concerns stations Leucate, Gruissan, Beauduc, Carteau, Fos, Carry, Marseille Grande Rade, Marseille Jetée, Toulon Grande Rade, Monaco and Menton. Often, the predominance of stress-tolerant 
taxa is probably the result of natural conditions. However, in some cases it may be due to a superimposed anthropogenic impact.

2) Faunas with a high percentage of sensitive species and a low percentage of stresstolerant species are indicative of sandy substrates with relatively low organic matter content and well oxygenated bottom waters. Such a situation was encountered at stations Cerbère, Collioure, Agde Ouest, Agde Est, Sète, Grau du Roi, Faraman, Cap

It appears that the information given by the group of stress-tolerant species is very similar (but Canaille, Ile Plane, Ile Maire, Embiez, Porquerolles, Lavandou, Ile du Levant, opposed) to the information given by the group of sensitive species. However, as shown in Figure 8b, sensitive species are well represented in all stations (from 16 to $76 \%$ ) whereas the percentage of stress-tolerant species appears to be more discriminative (from 0 to $46 \%$ ). This difference is essential for the development of a biotic index of ecological quality status. Although the group of stress-tolerant species apparently can inform us about the degree of stress at a particular station, it does not tell us whether this stress results entirely from natural conditions or is partly, or totally, due to an anthropogenic impact. Since the aim of biomonitoring studies is to evaluate the anthropogenic impact on the ecosystem (excluding natural eutrophication); it is absolutely essential to deconvolve these two parameters.

\section{9}

\subsection{Correction for natural eutrophication phenomena}

In this study, the analyses of the environmental parameters (water depth, organic matter, grain size fraction) highlighted the clear (natural) environmental differences between 1) stations located on West side of the Rhône River with relatively shallow water depths (18m depth in average) and clayey to fine sandy sediments; 2) stations located in front of the Rhône river mouth and in the Gulf of Fos with clayey sediments enriched in organic matter; and 3) the eastern stations with relatively important water depth (40m depth in average) and coarser sediments. Living foraminiferal faunas of the 31 analysed stations respond clearly to this natural variability of environmental parameters with changes in species composition. Foraminifera (and benthic fauna in general) are largely influenced by sediment grain size. A simple faunal analysis shows large differences between faunas from clayey and sandy substrates. In fact, faunas living on clayed substrates are more adapted to naturally enriched conditions (eutrophisation), often characterised by increased OM concentrations and 
841 sometimes seasonal low oxygen concentrations. For this reason stations with muddy

842 substrates tend to show an elevated proportion of stress-tolerant species, even if the concerned 843 ecosystem is exempt from anthropogenic impact.

844 We think therefore, that it is necessary to define reference conditions in function of grain size 845 distribution, in order to avoid a basic and erroneous interpretation of faunal data that would 846 consider any station with a clayey substrate of bad quality.

847 In our database, we selected 8 stations (Agde Ouest, Grau du Roi, Beauduc, Cap Canaille, 848 Embiez, Antibes 2, Antibes Nord and Nice) with different proportions of fine grain-sized 849 sediment ( $<63 \mu \mathrm{m}$ size fraction), which show minimal percentages of stress-tolerant species.

850 These stations were used to define the reference faunas, in other words, the percentages of 851 stress-tolerant species expected to be found in a natural environment with a certain grain-size 852 composition, without any anthropogenic impact (Figure 10). If only very few (1 to 3 )

853 reference stations are selected, there is the risk that they do not represent correctly all the 854 environmental conditions of the study area. Our method, based on 8 reference stations, 855 represents a wide range of coarse sand to clayey substrates, with many intermediate 856 conditions being represented. The stations Faraman, Lavandou and Porquerolles, which also 857 present very low percentages of tolerant species were not retained as reference stations 858 because of their low total number of individuals ( $<51$ ind.) which make them statistically less 859 robust.

860

861 Knowing the theoretical percentage of tolerant species in reference conditions for each grain 862 size (defined by the equation $\left.\left.\% T S_{r e f}=\exp (0.0302 *(\%<63 \mu \mathrm{m})+0.1496)-1\right)\right)$, it is then 863 possible to calculate the standardised percentage of tolerant species $\left(\% T S_{s t d}\right)$ using the 864 following formula, for a given grain size composition:

$$
\% T S_{s t d}=\frac{\left(\% T S_{x}-\% T S_{r e f}\right)}{\left(100-\% T S_{r e f}\right)} \times 100
$$

868 where $\% T S_{x}$ is the percentage of tolerant species at station $x$, and $\% T S_{\text {ref }}$ is the theoretical 869 percentage of tolerant species expected at a station with a certain proportion of $<63 \mu \mathrm{m}$ 870 particles, in the absence of anthropogenic impact (c.f. exponential curve equation).

871 The $\% T S_{s t d}$, which varies from 0 to 100 , describes the increase of the number of stress-tolerant 872 taxa with respect to a reference station with a similar grain-size. Exceptionally, some stations 873 can present a lower percentage of stress-tolerant species than the reference conditions, leading 
874 to negative values (Table 3, Figure 10). Values of $\% T S_{\text {std }}$ close to 0 are indicative of a very

875 high environmental quality, whereas values close to 100 would indicate a very high

876 anthropogenic impact.

877

878 The standardised percentages of tolerant species for 30 studied stations are presented in Table

8793 (except for station Marseille Grande Rade for which we don et have a grain size analyses).

880 Twenty-one stations out of 30 show a $\% T S_{\text {std }}$ below $10 \%$, suggesting that the ecological

881 quality at these stations is high, close to theoretical reference conditions. The other 9 stations

882 contain a $\% T S_{\text {std }}$ between 10 and 50, indicating that the percentage of stress-tolerant species is

883 higher than would be expected in natural conditions. This concerns particularly the stations

884 Carry, Marseille Jetée and Leucate stations which exhibit a $\% T S_{s t d}$ higher than $30 \%$. The

885 benthic foraminiferal faunas of these stations are very probably impacted by human activities.

886

8875 Conclusion

888

889 In the literature, the study of foraminiferal faunas along the French Mediterranean coast is 890 rather disperse, with some older studies dealing with total (dead and living individuals) 891 assemblages (Blanc-Vernet, 1969; Bizon and Bizon, 1984; Vénec-Peyré, 1984), and some 892 more recent studies on living foraminifera around the Rhône river mouth (Mojtahid et al., 893 2009, 2010; Goineau et al., 2011, 2012) Our study of 31 stations presents for the first time a 894 description of living (Rose Bengal stained) foraminiferal faunas along the entire French 895 Mediterranean coast except Corsica.

896 The comparative study, for 14 stations, of two different sediment intervals, $0-1 \mathrm{~cm}$ and $0-4 \mathrm{~cm}$, 897 clearly shows that the analysis of the uppermost centimetre of sediment is sufficient to obtain 898 relevant information needed for bio-monitoring purposes. In our sandy to silty coastal area, 899 intermediate to deep infaunal species are virtually absent so that the faunal composition of the 900 topmost centimetre is representative of the whole sediment column. This conclusion strongly 901 supports the recommendation of the FOBIMO group (Schönfeld et al., 2012).

902 Our analysis of the different faunal parameters led us to the conclusion that the use of 903 indicator species, such as stress-tolerant or sensitive species, is more relevant than the use of 904 diversity indices for the evaluation of ecosystem quality, at least in rather oligotrophic areas 905 such as the Mediterranean Sea. Finally, we propose a method to distinguish between natural 906 and anthropogenic eutrophication phenomena by determining the expected percentage of 
907 stress-tolerant taxa in natural environments, in function of sediment grain size, and by

908 correcting the observed percentage of stress-tolerant taxa accordingly. This study is a first

909 step towards the development of a foraminiferal index of ecosystem quality for the coastal

910 Mediterranean Sea that could be used in the context of the Marine Strategy Framework

911 Directive (2008/56/EC). Our index has to be tested at other stations, ideally located on a

912 gradient of disturbance. Furthermore, some aspects deserve to be further explored, such as the

913 pertinence of our list of tolerant species in other Mediterranean coastal areas, the potential of

914 the comparison of live and dead faunas to select indicator species, or the relevance of a

915 multimetric index (cf., M-AMBI) combining indicator species and diversity indices.

916

9176 Acknowledgements

918 We are grateful to the crew of Europe vessel (IFREMER) and scientists who participated to 919 the oceanographic cruise. We also thank Mélissa Gauthier (Angers University) who helped 920 for laboratory sample treatments. Finally, we would like to thank the Agence de l'Eau Rhône

921 Méditerranée et Corse for funding this study. 
Aloisi, J.C., Got, H. and Monaco, A., 1973. Carte géologique du précontinent languedocien du Cap Leucate à la pointe de Beauduc au 1/250000ième. In: I.I.f.A.S.a.E.S. (I.T.C.) (Editor), Netherlands.

Altenbach, A.V. and Sarnthein, M., 1989. Productivity Record in Benthic Foraminifera. In: W.H. Berger, Smetacek, V.S., Wefer G. (Editor), Productivity of the Ocean: Present and Past. Wiley, Chichester, pp. 255-269.

Alve, E., 1991. Benthic Foraminifera in Sediment Cores Reflecting Heavy-Metal Pollution in Sorfjord, Western Norway. Journal of Foraminiferal Research, 21(1): 1-19.

Alve, E., 1995. Benthic foraminiferal responses to estuarine pollution: a review. Journal of Foraminiferal Research, 25: 190-203.

Alve, E. and Nagy, J., 1986. Estuarine foraminiferal distribution in Sandebukta, a branch of the Oslo Fjord. Journal of Foraminiferal Research, 16: 157-175.

Armynot du Chatelet, E., Debenay, J.P. and Soulard, R., 2004. Foraminiferal proxies for pollution monitoring in moderately polluted harbors. Environmental pollution, 127: $27-40$.

Bandy, O.L., Ingle, J.C. and Resig, J.M., 1964. Foraminifera, Los Angeles County outfall area, California. Limnology and Oceanography, 9: 124-137.

Bandy, O.L., Ingle, J.C. and Resig, J.M., 1965. Modification of foraminiferal distribution by the Orange County outfall, California. Ocean Science and Ocean Engineering, Marine Technology Society, Transactions: 54-76.

Barmawidjaja, D.M., Jorissen, F.J., Puskaric, S. and van der Zwaan, G.J., 1992. Microhabitat selection by benthic foraminifera in the northern Adriatic Sea. Journal of Foraminiferal Research, 22(4): 297-317.

Barmawidjaja, D.M., van Der Zwaan, G.J., Jorissen, F.J. and Puskaric, S., 1995. 150 years of eutrophication in the northern Adriatic Sea, evidence from a benthic foraminiferal record. Marine Geology, 122(367-384).

Bassetti, M.A. et al., 2006. Sand bodies at the shelf edge in the Gulf of Lions (Western Mediterranean): Deglacial history and modern processes. Marine Geology, 234(1-4): 93-109.

Bergamin, L. et al., 2009. Benthic foraminifera from the coastal zone of Baia (Naples, Italy): Assemblage distribution and modification as tools for environmental characterisation. Marine Pollution Bulletin, 59(8-12): 234-244. 
Berné, S. and Gorini, C., 2005. The Gulf of Lions: An overview of recent studies within the French „Margins se program. Marine and Petroleum Geology, 22: 691-693.

Bernhard, J.M., 1988. Postmortem vital staining in benthic Foraminifera: Duration and importance in population and distributional studies. Journal of Foraminiferal Research, 18: $143-146$.

Bernhard, J.M. and Reimers, C.E., 1991. Benthic foraminiferal population fluctuations related to anoxia: Santa Barbara Basin. Biogeochemistry, 15(2): 1577-1585.

Bernhard, J.M. and Sen Gupta, B.K., 1999. Foraminifera of oxygen-depleted environments. In: B.K. Sen Gupta (Editor), Modern Foraminifera. Kluwer Academic Press, Dordrecht.

Bernhard, J.M., SenGupta, B.K. and Borne, P.F., 1997. Benthic foraminiferal proxy to estimate dysoxic bottom-water oxygen concentrations: Santa Barbara basin, US Pacific continental margin. Journal of Foraminiferal Research, 27(4): 301-310.

Bizon, G. and Bizon, J.J., 1984. Distribution des foraminifères sur le plateau continental au large du Rhône. In: J.J. Bizon and P.F. Burollet (Editors), Ecologie des Microorganismes en Méditerranée occidentale „ECOMED“. Association Française des Techniciens du Pétrole (AFTP), Paris, pp. 84-94.

Blanc-Vernet, L., 1969. Contribution à leétude des foraminifères de Méditerranée. Recueil des Travaux de la Station Marine d'Endoume, 64(48): 1-135.

Blanc-Vernet, L., 1984. Les foraminifères de l'herbier de Posidonia oceanica en Méditerranée: analyse des assemblages, aspects régionaux, application aux microfaunes fossiles. In: C.F. Boudouresque, A. Jeudy de Grissac and J. Olivier (Editors), International Workshop on Posidonia Oceanica Beds. GIS Posidonie Publications, Marseille, pp. 3-14.

Borja, A., Franco, J. and Pérez, V., 2000. A Marine Biotic Index to Establish the Ecological Quality of Soft-Bottom Benthos Within European Estuarine and Coastal Environments. Marine Pollution Bulletin, 40, No. , pp. (12): 1100-1114.

Bosc, E., Bricaud, A. and Antoine, D., 2004. Seasonal and interannual variability in algal biomass and primary production in the Mediterranean Sea, as derived from 4 years of SeaWiFS observations. Global Biogeochemical Cycles, 18(1).

Bouchet, V.M.P., Alve, E., Rygg, B. and Telford, R.J., 2012. Benthic foraminifera provide a promising tool for ecological quality assessment of marine waters. Ecological Indicators, 23: 66-75. 
Bouchet, V.M.P., Debenay, J.P., Sauriau, P.-G., Radford-Knoery, J. and Soletchnik, P., 2007. Effects of short-term environmental disturbances on living benthic foraminifera during the Pacific oyster summer mortality in the Marennes-Oléron Bay (France). Marine Environmental Research, 64: 358-383.

Boudouresque, C.F. et al., 2006. Préservation et conservation des herbiers à Posidonia oceanica. Ramoge Pub.: 1-202.

Boudouresque, C.F. et al., 2000. A monitoring network based on the seagrass Posidonia oceanica in the Northwerstern Mediterranean Sea. Biologia Marina Mediterranea, 7(2): 328-331.

Buosi, C., Armynot du Chatelet, E. and Cherchi, A., 2012. Benthic Foraminiferal Assemblages in the Current-Dominated Strait of Bonifacio (Mediterranean Sea). Journal of Foraminiferal Research, 42(1): 39-55.

Burone, L., Venturini, N., Sprechmann, P., Valente, P. and Muniz, P., 2006. Foraminiferal responses to polluted sediments in the Montevideo coastal zone, Uruguay. Marine Pollution Bulletin, 52(1): 61-73.

Buzas, M.A., Culver, S.J. and Jorissen, F.J., 1993. A statistical evaluation of the microhabitats of living (stained) infaunal benthic foraminifera. Marine Micropaleontology, 20(3-4): 311-320.

Cherchi, A. et al., 2009. Benthic foraminifera response and geochemical characterization of the coastal environment surrounding the polluted industrial area of Portovesme (South-Western Sardinia, Italy). Marine Pollution Bulletin, 59(8-12): 281-296.

Clark, D.E., 1971. Effects of aquaculture outfall on benthonic foraminifera in Clam Bay, Nova Scotia. Maritime Sediments, 7: 76-84.

Coccioni, R., Frontalini, F., Marsili, A. and Mana, D., 2009. Benthic foraminifera and trace element distribution: A case-study from the heavily polluted lagoon of Venice (Italy). Marine Pollution Bulletin, 59(8-12): 257-267.

Coppa, M.G. and Di Tuoro, A., 1995. Preliminary data on the Holocene foraminifera of the Cilento continental shelf (Tyrrhenian Sea). Revista Espanola de Paleontologia, 10(2): 161-174.

Corliss, B.H., 1985. Microhabitats of benthic foraminifera within deep-sea sediments. Nature, 314: 435-438.

Corliss, B.H., 1991. Morphology and microhabitat preferences of benthic foraminifera from the northwest Atlantic Ocean. Marine Micropaleontology, 17(3-4): 195-236. 
Corliss, B.H. and Emerson, S., 1990. Distribution of Rose Bengale stained deep-sea benthic foraminifera from the Nova Scotian continental margin and Gulf of Maine. Deep-Sea Research Part I, 37(3): 381-400.

Dauvin, J.C. and Ruellet, T., 2007. Polychaete/amphipod ratio revisited. Marine Pollution Bulletin, 55: 215-224.

de Nooijer, L.J., Duijnstee, I.A.P., Bergman, M.J.N. and van der Zwaan, G.J., 2008. The ecology of benthic foraminifera across the Frisian Front, southern North Sea. Estuarine, Coastal and Shelf Science, 78(4): 715-726.

De Rijk, S., Jorissen, F.J., Rohling, E.J. and Troelstra, S.R., 2000. Organic flux control on bathymetric zonation of Mediterranean benthic foraminifera. Marine Micropaleontology, 40(3): 151-166.

Debenay, J.P., 2000. Foraminifers of tropical paralic environments. Micropaleontology, 46 (Supplement 1): 153-60.

Debenay, J.-P. and Redois, F., 1997. Distribution of the twenty seven dominant species of shelf benthic foraminifers on the continental shelf, north of Dakar (Senegal). Marine Micropaleontology, 29(3-4): 237-255.

Denoyelle, M., Jorissen, F., Martin, D., Galgani, F. and Miné, J., 2010. Comparison of benthic foraminifera and macrofaunal indicators of the impact of oil-based drill mud disposal. Marine Pollution Bulletin, 60(11): 2007-2021.

Devlin, M., Best, M. and Haynes, D., 2007. Implementation of the Water Framework Directive in European marine waters. Marine Pollution Bulletin, 55(Spec. Issue 1-6).

Diaz, R.J., Solan, M. and Valente, R.M., 2004. A review of approaches for classifying benthic habitats and evaluating habitat quality. Journal of Environmental Management, 73: 165-181.

Diz, P. and Francés, G., 2008. Distribution of live benthic foraminifera in the Ría de Vigo (NW Spain). Marine Micropaleontology, 66(3-4): 165-191.

Diz, P., Francés, G. and Rosón, G., 2006. Effects of contrasting upwelling-downwelling on benthic foraminiferal distribution in the Ría de Vigo (NW Spain). Journal of Marine Systems, 60(1-2): 1-18.

Donnici, S. and Serandrei-Barbero, R., 2002. The benthic foraminiferal communities of the northern Adriatic continental shelf. Marine Micropaleontology, 44(3-4): 93-123.

Duchemin, G. et al., 2008. New monitoring tool for assessing environmental impact of offshore drilling activities: benthic foraminifera. Society of Petroleum Engineers Journal, Paper 111959: 8 pp. 
1057

1058

1059

1060

1061

1062

1063

1064

1065

1066

1067

1068

1069

1070

1071

1072

1073

1074

1075

1076

1077

1078

1079

1080

1081

1082

1083

1084

1085

1086

1087

1088

1089

1090

Duijnstee, I., de Lugt, I., Vonk Noordegraaf, H. and van der Zwaan, B., 2004. Temporal variability of foraminiferal densities in the northern Adriatic Sea. Marine Micropaleontology, 50(1-2): 125-148.

Duijnstee, I.A.P., Ernst, S.R. and van der Zwaan, G.J., 2003. Effect of anoxia on the vertical migration of benthic foraminifera. Marine Ecology Progress Series, 246: 85-94.

Duros, P. et al., 2011. Live (stained) benthic foraminifera in the Whittard Canyon, Celtic margin (NE Atlantic). Deep-Sea Research Part I, 58(2): 128-146.

Durrieu de Madron, X. et al., 2000. Particulate matter and organic carbon budgets for the Gulf of Lions (NW Mediterranean). Oceanologica Acta, 23(6): 717-730.

Durrieu, J. et al., 2006. Aged drilled cuttings offshore Gabon: New methodology for assessing their impact. Society of Petroleum Engineers Journal, Paper 98414: 8 pp.

Eberwein, A. and Mackensen, A., 2006. Regional primary productivity differences off Morocco (NW-Africa) recorded by modern benthic foraminifera and their stable carbon isotopic composition. Deep Sea Research I, 53(8): 1379-1405.

Ernst, S., Bours, R., Duijnstee, I. and van der Zwaan, B.D., 2005. Experimental effects of an organic matter pulse and oxygen depletion on a benthic foraminiferal shelf community. Journal of Foraminiferal Research, 35(3): 177-197.

Ernst, S., Duijnstee, I. and van der Zwaan, B., 2002. The dynamics of the benthic foraminiferal microhabitat: Recovery after experimental disturbance. Marine Micropaleontology, 46(3-4): 343-361.

Fontanier, C. et al., 2008. Live foraminifera from the open slope between Grand Rhône and Petit Rhône Canyons (Gulf of Lions, NW Mediterranean). Deep-Sea Research Part I, 55(11): 1532-1553.

Fontanier, C. et al., 2002. Live benthic foraminiferal faunas from the Bay of Biscay: faunal density, composition, and microhabitats. Deep-Sea Research Part I, 49: 751-785.

Frontalini, F. et al., 2009. Benthic foraminifera as bio-indicators of trace element pollution in the heavily contaminated Santa Gilla lagoon (Cagliari, Italy). Marine Pollution Bulletin, 58(6): 858-877.

Frontalini, F. and Coccioni, R., 2008. Benthic foraminifera for heavy metal pollution monitoring: A case study from the central Adriatic Sea coast of Italy. Estuarine, Coastal and Shelf Science, 76: 404-417.

Frontalini, F. and Coccioni, R., 2011. Benthic foraminifera as bioindicators of pollution: A review of Italian research over the last three decades. Revue de micropaléontologie, 54: $115-127$. 
Gobert, S. et al., 2009. Assessment of the ecological status of Mediterranean French coastal waters as required by the Water Framework Directive using the Posidonia oceanica Rapid Easy Index: PREI. Marine Pollution Bulletin, 58(11): 1727-1733.

Goineau, A. et al., 2012. Temporal variability of live (stained) benthic foraminiferal faunas in a river-dominated shelf? Faunal response to rapid changes of the river influence (Rhône prodelta, NW Mediterranean). Biogeosciences, 9: 1367-1388.

Goineau, A. et al., 2011. Live (stained) benthic foraminifera from the Rhône prodelta (Gulf of Lion, NW Mediterranean): Environmental controls on a river-dominated shelf. Journal of Sea Research, 65(1): 58-75.

Gomez Gesteira, L. and Dauvin, J.C., 2000. Amphipods are good bioindicators of the impact of oil spills on soft-bottom macrobenthic communities. Marine Pollution Bulletin, 40: 1017-1027.

Gooday, A., Levin, L.A., Linke, P. and Heeger, T., 1992. The role of benthic foraminifera in deep-sea food webs and carbon cycling. In: G.T.a.P. Rowe, V. (Editor), Deep-sea food chains and the Global Carbon cycle. Kluwer Academic Publishers, The Netherlands, pp. 63-91.

Gooday, A.J., 1994. The biology of deep-sea foraminifera: a review of some advantages and their applications in paleoceanography. Palaios, 9: 14-31.

Gooday, A.J., Bernhard, J.M., Levin, L.A. and Suhr, S.B., 2000. Foraminifera in the Arabian Sea oxygen minimum zone and other oxygen-deficient settings: Taxonomic composition, diversity, and relation to metazoan faunas. Deep-Sea Research Part II, 47(1-2): $25-54$

Gooday, A.J. and Rathburn, A.E., 1999. Temporal variability in living deep-sea foraminifera: a review. Earth-Science Reviews, 46: 187-212.

Guimerans, P.V. and Currado, J.L.C., 1999. Distribution of Planorbulinacea (benthic foraminifera) assemblages in surface sediments on the northern margin of the Gulf of Cadiz. Boletin del Instituto Espanol de Oceanografia, 15(1-4): 181-190.

Hammer, Ø. and Harper, D., 2005. Paleontological Data Analysis. Blackwell Oxford, 351 pp. Hayek, L.E.C. and Buzas, M.A., 1997. Surveying Natural Populations. Columbia University Press, New York, 563 pp.

Helder, W. and Bakker, J.F., 1985. Shipboard comparison of micro- and mini-electrodes for measuring oxygen in marine sediments. Limnology and Oceanography, 30: 11061109. 
Herguera, J.C. and Berger, W.H., 1991. Paleoproductivity from benthic foraminifera abundance; glacial and postglacial change in the west-equatorial Pacific. Abstracts with Program Geological Society of America, 23(5): 107.

Hess, S. and Kuhnt, W., 1996. Deep-sea benthic foraminiferal recolonization of the $1991 \mathrm{Mt}$. Pinatubo ash layer in the South China Sea. Marine Micropaleontology, 28: 171-197. Hurlbert, S.H., 1971. The Nonconcept of Species Diversity: A Critique and Alternative Parameters. Ecology, 52(4): 577-586.

Hyams-Kaphzan, O., Almogi-Labin, A., Benjamini, C. and Herut, B., 2009. Natural oligotrophy vs. pollution-induced eutrophy on the SE Mediterranean shallow shelf (Israel): Environmental parameters and benthic foraminifera. Marine Pollution Bulletin, 58(12): 1888-1902.

Jorissen, F., 1988. Benthic foraminifera from the Adriatic Sea; Principles of phenotypic variation. Utrecht Micropaleontological Bulletins, 37: $174 \mathrm{pp}$.

Jorissen, F.J., 1987. The distribution of benthic foraminifera in the Adriatic Sea. Marine Micropaleontology, 12: 21-48.

Jorissen, F.J., Barmawidjaja, D.M., Puskaric, S. and van der Zwaan, G.J., 1992. Vertical distribution of benthic foraminifera in the northern Adriatic Sea: The relation with the organic flux. Marine Micropaleontology, 19: 131-146.

Jorissen, F.J. et al., 2009. Impact of oil-based drill mud disposal on benthic foraminiferal assemblages on the continental margin off Angola. Deep-Sea Research Part II, 56(23): 2270-2291.

Jorissen, F.J., de Stigter, H.C. and Widmark, J.G.V., 1995. A conceptual model explaining benthic foraminiferal microhabitats. Marine Micropaleontology, 22: 3-15.

Jorissen, F.J., Fontanier, C. and Thomas, E., 2007. Chapter Seven Paleoceanographical Proxies Based on Deep-Sea Benthic Foraminiferal Assemblage Characteristics. In: C. Hillaire-Marcel and A. De Vernal (Editors), Paleoceanography of the Late Cenozoic. Developments in Marine Geology. Elsevier, pp. 263-325.

Jorissen, F.J., Wittling, I., Peypouquet, J.P., Rabouille, C. and Relexans, J.C., 1998. Live benthic foraminiferal faunas off Cap Blanc, NW Africa: community structure and microhabitats. Deep-Sea Research Part I, 45: 2157-2188.

Kim, J.-H. et al., 2006. Origin and distribution of terrestrial organic matter in the NW Mediterranean (Gulf of Lions): Exploring the newly developed BIT index. Geochemistry Geophysics Geosystems, 7: doi:10.1029/2006GC001306. 
Kitazato, H., 1988. Ecology of benthic foraminifera in the tidal zone of a rocky shore. Revue de micropaléontologie, Spec. No. 2: 815-825.

Langer, M.R., 1993. Epiphytic Foraminifera. Marine Micropaleontology, 20(3-4): 235-265.

Langezaal, A.M. et al., 2006. The influence of seasonal processes on geochemical profiles and foraminiferal assemblages on the outer shelf of the Bay of Biscay. Continental Shelf Research, 26(15): 1730-1755.

Licari, L.N., Schumacher, S., Wenzhöfer, F., Zabel, M. and Mackensen, A., 2003. Communities and microhabitats of living benthic foraminifera from the tropical east Atlantic: impact of different productivity regimes. Journal of Foraminiferal Research, 33: $10-31$.

Martins, V. et al., 2007. A multiproxy approach of the Holocene evolution of shelf-slope circulation on the NW Iberian Continental Shelf. Marine Geology, 239: 1-18.

Mathieu, R., 1986. Sédiments et foraminifères actuels de la marge continentale atlantique du maroc, $\mathrm{n}^{\circ} 86-14$. Thèse Sci. Univ. Paris VI, $420 \mathrm{pp}$.

Mendes, I., Gonzalez, R., Dias, J.M.A., Lobo, F. and Martins, V., 2004. Factors influencing recent benthic foraminifera distribution on the Guadiana shelf (Southwestern Iberia). Marine Micropaleontology, 51: 171- 192.

Milker, Y. et al., 2009. Distribution of recent benthic foraminifera in shelf carbonate environments of the Western Mediterranean Sea. Marine Micropaleontology, 73(3-4): 207-225.

Millot, C. and Taupier-Letage, I., 2005. Additional evidence of LIW entrainment across the Algerian subbasin by mesoscale eddies and not by a permanent westward flow. Progress in Oceanography, 66(2-4): 231-250.

Mojtahid, M., 2007. Les foraminifères benthiques : bio-indicateurs d"eutrophisation naturelle et anthropique en milieu marin franc, Angers, France, $390 \mathrm{pp}$.

Mojtahid, M. et al., 2006. Benthic foraminifera as bio-indicators of drill cutting disposal in

Mojtahid, M., Jorissen, F., Lansard, B. and Fontanier, C., 2010. Microhabitat Selection of Benthic Foraminifera in Sediments Off the Rhône River Mouth (NW Mediterranean). Journal of Foraminiferal Research, 40(3): 231-246.

Mojtahid, M. et al., 2009. Spatial distribution of live benthic foraminifera in the Rhône prodelta: Faunal response to a continental-marine organic matter gradient. Marine Micropaleontology, 70: 177-200. 
Mojtahid, M., Jorissen, F. and Pearson, T.H., 2008. Comparison of benthic foraminiferal and macrofaunal responses to organic pollution in the Firth of Clyde (Scotland). Marine Pollution Bulletin, 56(1): 42-76.

Moodley, L., Van der Zwaan, G.J., Herman, P.M.J., Kempers, L. and Van Breugel, P., 1997. Differential response of benthic meiofauna to anoxia with special reference to Foraminifera (Protista: Sarcodina). Marine Ecology Progress Series, 158: 151-163.

Morigi, C., Jorissen, F.J., Gervais, A., Guichard, S. and Borsetti, A.M., 2001. Benthic foraminiferal faunas in surface sediments off NW Africa: Relationship with the organic flux to the ocean floor. Journal of Foraminiferal Research, 31: 350-368.

Morvan, J., Le Cadre, V., Jorissen, F. and Debenay, J.P., 2004. Foraminifera as potential bioindicators of the "Erika" oil spill in the Bay of Bourgneuf: Field and experimental studies. Aquatic Living Resources, 17(3): 317-322.

Murray, J.W., 1973. Distribution and Ecology of Living Benthic Foraminiferids, New York.

Murray, J.W., 1986. Living and dead Holocene foraminifera of Lyme Bay, southern England. Journal of Foraminiferal Research, 16: 347-352.

Murray, J.W., 1989. Syndepositional dissolution of calcareous foraminifera in modern shallow water sediments. Marine micropaleontology, 15: 117-121.

Murray, J.W., 1991. Ecology and distribution. BENTHOS'90. Tokai University Press, Sendai. Murray, J.W., 2006. Ecology and applications of benthic foraminifera. Cambridge University Press, Cambridge, 426 pp.

Nigam, R., Saraswat, R. and Panchang, R., 2006. Application of foraminifers in ecotoxicology: Retrospect, perspect and prospect. Environment International, 32: 273-283.

Ohga, T. and Kitazato, H., 1997. Seasonal changes in bathyal foraminiferal populations in response to the flux of organic matter (Sagami Bay, Japan). Terra Nova, 9(1): 33-37.

Pairaud, I. and Desmare, S., 2011. Courantologie de la sous-région marine Méditerranée occidentale DCSMM/EI/MO, Ministère de l'Écologie, du Développement Durable, des Transports et du Logement, Ref. DCSMM/EI/EE/MO/1.1.6/2011, pp. 10.

Panieri, G., Gamberi, F., Marani, M. and Barbieri, R., 2005. Benthic foraminifera from a recent, shallow-water hydrothermal environment in the Aeolian Arc (Tyrrhenian Sea). Marine Geology, 218: 207-229.

Pearson, T.H. and Rosenberg, R., 1978. Macrobenthic succession in relation to organic enrichment and pollution of the marine environment. Oceanography and Marine Biology: an Annual Review, 16: 229-311. 
Pielou, E.C., 1966. The measurement of diversity in different types of biological collections. Journal of Theoretical Biology, 13: 131-144.

Pielou, E.C., 1975. Ecological Diversity. Wiley, New York, 165 pp pp.

Platon, E., Sen Gupta, B.K., Rabalaisc, N.N. and Turner, R.E., 2005. Effect of seasonal hypoxia on the benthic foraminiferal community of the Louisiana inner continental shelf, the 20th century record. Marine Micropaleontology, 54: 263-283.

Pont, D., 1997. Les débits solides du Rhône à proximité de son embouchure: données récentes (1994-1995). Revue de géographie, 72: 13-33.

Pont, D., Simonnet, J.P. and Walter, A.V., 2002. Medium-term changes in suspended sediment delivery to the ocean: Consequences of catchment heterogeneity and river management (Rhône river, France). Estuarine, Coastal and Shelf Science, 54: 1-18.

Pujos, M., 1976. Ecologie des foraminifères benthiques et des thecamoebiens de la Gironde et du plateau continental sud-Gascongne. Application à la connaissance du Quaternaire terminal de la région ouest-Gironde., Mémoires de l'Institut de Géologie du Bassin d $^{\text {eeAquitaine, }} 314 \mathrm{pp}$.

Pusceddu, A., Dell'Anno, A., Fabian, M. and Danovaro, R., 2009. Quantity and bioavailability of sediment organic matter as signatures of benthic trophic status. Marine Ecology Progress Series, 375: 41-52.

Raimbault, P. and Durrieu de Madron, X., 2003. Research activities in the Gulf of Lion (NW Mediterranean) within the 1997-2001 PNEC project. Oceanologica Acta, 26: 291298.

Rathburn, A.E. and Corliss, B.H., 1994. The ecology of living (stained) deep-sea benthic foraminifera from the Sulu Sea. Paleoceanography, 9(1): 87-150.

Redois, F. and Debenay, J.-P., 1996. Influence du confinement sur la répartition des foraminifères benthiques : exemple de l'estran d'une ria mésotidale de Bretagne méridionale. Revue de Paléobiologie, 15(1): 243-260.

Resig, J.M., 1960. Foraminiferal ecology around ocean outfalls off southern California, Waste Disposal in the Marine Environment. Pergamon Press, London, pp. 104-121.

Revsbech, N.P., 1983. In-situ measurements of oxygen profiles of sediments by use of oxygen microelectrodes. In: E.F. Ganuger, H. (Editor), Polarographic Oxygen Sensors. Springer, Berlin, pp. 265-273.

Revsbech, N.P. and Jørgensen, B.B., 1986. Microelectrodes: their use in microbial ecology. Advances in Microbial Ecology, 9: 293-352. 
Romano, E. et al., 2009. The impact of the Bagnoli industrial site (Naples, Italy) on seabottom environment. Chemical and textural features of sediments and the related response of benthic foraminifera. Marine Pollution Bulletin, 59(8-12): 245-256.

Rosenberg, R., Blomqvist, M., Nilsson, H.C., Cederwall, H. and Dimming, A., 2004. Marine quality assessment by use of benthic species-abundance distributions: a proposed new protocol within the European Union Water Framework Directive. Marine Pollution Bulletin, 49: 728-739.

Sabbatini, A. et al., 2012. Foraminiferal assemblages and trophic state in coastal sediments of the Adriatic Sea. Journal of Marine Systems, 105: 163-174.

Sabbatini, A. et al., 2010. Modern benthic foraminifers at Northern shallow sites of Adriatic Sea and soft-walled, monothalamous taxa: a brief overview. Micropaleontology, 56(34): 359-376.

Sanders, H.L., 1968. Marine Benthic Diversity: A Comparative Study. The American Naturalist, 102(925): 243-282.

Schmiedl, G. et al., 2000. Trophic control of benthic foraminiferal abundance and microhabitat in the bathyal Gulf of Lions, western Mediterranean Sea. Marine Micropaleontology, 40: 167-188.

Schmiedl, G. et al., 2003. Benthic foraminiferal record of ecosystem variability in the eastern Mediterranean Sea during times of sapropel S-5 and S-6 deposition. Palaeogeography Palaeoclimatology Palaeoecology, 190: 139-164.

Schönfeld, J., 2002. Recent benthic foraminiferal assemblages in deep high-energy environments from the Gulf of Cadiz (Spain). Marine Micropaleontology, 44(3-4): 141-162.

Schönfeld, J. et al., 2012. The FOBIMO (FOraminiferal BIo-MOnitoring) initiative-Towards a standardised protocol for soft-bottom benthic foraminiferal monitoring studies. Marine Micropaleontology, 94-95: 1-13.

Scott, D.B. et al., 2005. Pollution monitoring in two North American estuaries: Historical reconstructions using benthic foraminifera. Journal of Foraminiferal Research, 35: 6582.

Scott, G.A., Scourse, J.D. and Austin, W.E.N., 2003. The distribution of benthic foraminifera in the Celtic Sea: The significance of seasonal stratification. Journal of Foraminiferal Research, 33(1): 32-61. 
Seiglie, G.A., 1968. Foraminiferal assemblages as indicators of high organic carbon content in sediments and of polluted waters. American Association of Petroleum Geologists Bulletin, 52: 2231 - 2241.

Seiglie, G.A., 1971. A preliminary note on the relationships between foraminifers and pollution in two Puerto Rican bays. Caribbean Journal of Science, 11: 93-98.

Sempéré, R., Charrière, B., VanWambeke, F. and Cauwet, G., 2000. Carbon inputs of the Rhône River to the Mediterranean Sea. Global Biogeochemical Cycles, 14: 669-681.

Sen Gupta, B.K. and Machain-Castillo, M.L., 1993. Benthic foraminifera in oxygen-poor habitats. Marine Micropaleontology, 20(3-4): 183-201.

Shirayama, Y., 1984. The abundance of deep sea meiobenthos in the Western Pacific in relation to environmental factors. Oceanologica Acta, 7: 113-121.

Simboura, N. and Zenetos, A., 2002. Benthic indicators to use in ecological quality classification of Mediterranean soft bottoms marine ecosystems, including a new biotic index. Mediterranean Marine Science, 3/2: 77-111.

Spindler, M., 1980. The pelagic golfweed Sargassum natans as a habitat for the benthic foraminifera Planorbulina acervalis et Rosalina globularis. Neues Jahrbuch fur Mineralogie, Geologie und Palaontologie, Monatshefte 9: 569-580.

Teodoro, A.C. et al., 2010. Analysis of foraminifera assemblages and sediment geochemical properties to characterise the environment near Araca and Saco da Cape la domestic sewage submarine outfalls of Sao Sebastiao Channel, Sao Paulo State, Brazil. Marine Pollution Bulletin, 60(4): 536-553.

Thill, A. et al., 2001. Evolution of particle size and concentration in the Rhône river mixing zone: Influence of salt flocculation. Continental Shelf Research, 21: 2127-2140.

van der Zwaan, G.J. et al., 1999. Benthic foraminifers: proxies or problems? A review of paleoecologial concepts. Earth-Sciences Reviews, 46: 213-236.

van der Zwaan, G.J. and Jorissen, F.J., 1991. Biofacial patterns in river-induced shelf anoxia. In: R.V. Tyson and T.H. Pearson (Editors), Modern and Ancient Continental Shelf Anoxia. Geological Society Special Publication No 58, London, pp. 65-82.

Vénec-Peyré, M.T., 1984. Etude de la distribution des foraminifères vivant dans la Baie de Banyuls-sur-Mer. In: J.J. Bizon and P.F. Burolet (Editors), Ecologie des microorganismes en Méditerranée occidentale "Ecomed". Association française des Techniciens du Pétrole, Paris, pp. 60-80. 
Vénec-Peyré, M.T. and Le Calvez, Y., 1981. Etude des foraminifères de l'herbier à Posidonies de Banyuls-sur-Mer, $106^{\mathrm{e}}$ Congrès national des sociétés savantes, Perpignan, pp. 191203.

Vénec-Peyré, M.T. and Le Calvez, Y., 1988. Les foraminifères épiphytes de l'herbier de Posidonies de Banyuls-sur-Mer (Méditerranée occidentale): Etude des variations spatiotemporelles du peuplement. Cahiers de micropaleontologie, NS, 3: 21-40.

Vilela, C.G., Batista, D.S., Baptista Neto, J.A. and Ghiselli, R.O., Jr., 2011. Benthic foraminifera distribution in a tourist lagoon in Rio de Janeiro, Brazil: A response to anthropogenic impacts. Marine Pollution Bulletin, 62(10): 2055-2074.

Villanueva Guimerans, P. and Cervera Currado, J.L., 1999. Distribution of Planorbulinacea (benthic framinifera) assemblages in surface sediments on the northern margin of Gulf of Cadiz. Boletin del Instituto Espanol de Oceanografia, 15: 181- 190.

Walton, W.R., 1952. Techniques for recognition of living foraminifera. Contributions from the Cushman Foundation for Foraminiferal Research, 3: 56-60.

Watkins, J.G., 1961. Foraminiferal ecology around the Orange County, California, ocean sewer outfall. Micropaleontology, 7: 199-206.

Word, J.Q., 1979. The infaunal trophic index. In: E. Segundo (Editor), Annual Report 1978, Southern California Coastal Water Research Project, Los Angeles, California, USA, pp. 19-41. 
Figure 1: Localisation of the sampling stations along the French Mediterranean coast.

Figure 2: Environmental parameters for the 31 sampling stations, from west (left side) to east (right side) stations : a) water depth, b) percentage of organic matter, c) percentage of clay and silt $(<63 \mu \mathrm{m})$, d) percentage of very fine to fine sand $(63-250 \mu \mathrm{m})$, and e) percentage of medium to coarse sand $(>250 \mu \mathrm{m})$.

Figure 3: Density and diversity (species number) of living foraminiferal faunas for the 31 sampling stations, from west (left side) to east (right side), considering either $0-1 \mathrm{~cm}$ (black/diamonds) or $0-4 \mathrm{~cm}$ (white/squares) sediment intervals: a) living foraminiferal density (number of specimens standardised for $50 \mathrm{~cm}^{2}$, crosses notify samples for which only the first $\mathrm{cm}$ of sediment was analysed), b) species richness, c) Shannon-Wiener index, d) Equitability index, and e) $\mathrm{ES}_{50}$. NB: For station Toulon Grande Rade data are based on a study of the 0-1 and 0$3 \mathrm{~cm}$ intervals.

Figure 4: Vertical distribution of living foraminiferal faunas for stations of group A. Foraminiferal densities are standardised for $50 \mathrm{~cm}^{3}$. Major species ( $>5 \%$ of the total fauna of the core) are presented separately from the rest of the species gathered in «others ». NB: $\mathrm{x}$ and $\mathrm{y}$ axes scales change according to the stations. Figure 4 and 5 should be in color on both the web and on printed version.

Figure 5: Vertical distribution of living foraminiferal faunas for stations of group B. Foraminiferal densities are standardised for $50 \mathrm{~cm}^{3}$. Major species ( $>5 \%$ of the total fauna of the core) are presented separately from the rest of the species gathered in «others ». NB: $\mathrm{x}$ and $\mathrm{y}$ axes scales change according to the stations. Figure 4 and 5 should be in color on both the web and on printed version.

Figure 6: Ternary diagram representing stations according to the fractions of the 3 main groups of foraminifera (perforate, porcelaneous and agglutinated taxa) in the living fauna in the $0-1 \mathrm{~cm}$ interval. Stations dominated by perforate foraminifera plot in the red area (lower right triangle), those dominated by porcelaneous taxa in the blue area (upper triangle), and those dominated by agglutinated taxa in the green area (lower left triangle).

Figure 6 should be in color only on the web version, and in black and white on printed version.

Figure 7: Canonical correspondence analysis (Axis 1 vs. Axis 2) performed on environmental parameters and the percentages of the 3 main foraminiferal groups (without considering Marseille Grande Rade and Cap Canaille for which no environmental data were available).

Figure 8: Percentage of indicative species in the sample ( $0-1 \mathrm{~cm}$ interval) at each station (West-East transect): a) epiphytic species, b) sensitive species, and c) stress-tolerant species.

Figure 9: Canonical correspondence analysis (Axis 1 vs. Axis 2) performed on environmental parameters and the percentages of the indicative species groups: epiphytic species, stress-tolerant and sensitive species (without considering Marseille Grande Rade and Cap Canaille for which no environmental data were available).

Figure 10: Percentage of stress-tolerant species versus the percentage of particles $<63 \mu \mathrm{m}$ in the different stations studied along the Mediterranean coast. The exponential curve is thought to represent the percentage of stress-tolerant species in natural conditions (without anthropogenic influence). 
Table 1: Oxygen penetration depth (OPD) and Average Living Depth $\left(\mathrm{ALD}_{5} / \mathrm{ALD}_{6}\right)$ for stations where oxygen profiles were performed and average living depth was calculated for cores of 5 or $6 \mathrm{~cm}$ length (depending on the slicing) in order to compare the $\mathrm{ALD}_{\mathrm{x}}$ of different stations. NB: $\mathrm{ALD}_{3}$ for Toulon and $\mathrm{ALD}_{4}$ for Agde Est. Environmental parameters are added to compare with the vertical distribution of foraminifera.

Table 2: List of major species (relative density $>5 \%$ in at least one of the stations studied between $0-1 \mathrm{~cm}$ ).

Table 3: Values of the standardised percentage of stress-tolerant species. The parameters required for the 1392 calculation of the $\% S T_{\text {std }}$ are indicated. Data are missing for Marseille Grande Rade due to the lack of particle size measurements at this station. 
Appendix A: Localisation (WGS84) and water depth of the stations. The sediment layers analysed for living foraminiferal faunas are indicated.

Appendix B: Environmental parameters and faunal parameters (considering foraminiferal faunas from the $>150 \mu \mathrm{m}$ size fraction and $0-1 \mathrm{~cm}$ sediment interval) calculated for the 31 stations analysed in this study (presented from West to East).

Appendix C: Linear correlations between environmental and faunal parameters (upper right triangle shows

$1404 \mathrm{p}$ values and lower left triangle shows $\mathrm{r}$ values) considering foraminiferal faunas from the $>150 \mu \mathrm{m}$ size fraction and $0-1 \mathrm{~cm}$ sediment interval.

Appendix D: Example of an oxygen profile, measured at station Carteau.

Appendix E: Wilcoxon tests $(Z)$ results and their corresponding probabilities $(p)$ in order to test similarities of major species ( $>5 \%$ ) between intervals $0-1$ and $0-4 \mathrm{~cm}$.

1409 Appendix F: Linear correlation (r) between the relative densities of the major species (see Table 2 for the 1410 meaning of species abbreviations) and the environmental parameters available for this study. The statistically 1411 significant correlations $(\mathrm{p}<0.05)$ are indicated in bold.

1412 Appendix G: Evidence from the literature that support our choice to attribute species to stress-tolerant and sensitive (including epiphytic species) groups.

1414 
Supplementary material 1: Plates showing MEB pictures of major species.

Plate 1: 1) Lagenammina sp. a, Fréjus, 1a: side view, 1b: aperture view; 2) Lagenammina sp. b, Marseille Jetée; Textularia agglutinans, Marseille Jetée; 7) Reophax scorpiurus, Marseille Jetée; 8) Reophax fusiformis, Fréjus; 9) Reophax subfusiformis, Grau du Roi; 10) Ammoscalaria pseudospiralis, Carteau, 9a: front view, 9b: side view; 11) Quinqueloculina seminula, Rhône prodelta (station 10, 80m) (Mojtahid et al., 2009); 12) Triloculina trigonula, Grau du Roi; 13) Sigmoilina grata, Fréjus; 14) Quinqueloculina aspera, Agde Est, 13a: side view, 13b: aperture view; 15) Quinqueloculina bosciana, Antibes Nord; 16) Adelosina longirostra, Calvi, Corsica. NB: scale bar is $100 \mu \mathrm{m}$.

Plate 2: 1) Rectuvigerina phlegeri, Marseille Jetée; 2) Valvulineria bradyana, Carteau, 2a: dorsal side, 2b: aperture view, 2c: ventral side; 3) Cancris auriculus, Marseille Jetée, 3a: dorsal side, 3b: ventral side; 4) Nonion scaphum, Grau du Roi, 4a: side view, 4b: aperture view; 5) Nonionella turgida, Leucate, 5a: dorsal side, 5b: aperture view, 5c: ventral side; 6) Nonion depressulum, Leucate, 6a: side view, 6b: aperture view; 7) Pseudoeponides falsobeccarii, Menton, 7a: dorsal side, 7b: aperture view, 7c: ventral side; 8) Bulimina aculeata, Menton. NB: scale bar is $100 \mu \mathrm{m}$ except for $1 \mathrm{~b}$ where it corresponds to $10 \mu \mathrm{m}$.

Plate 3: 1) Asterigerinata mamilla, Marseille Jetée, 1a: dorsal side, 1b: aperture view, 1c: ventral side; 2) Hanzawaia boueana, Marseille Jetée, 2a: dorsal side, 2b: ombilical view; 3) Planorbulina mediterranensis, Carry; 4) Cibicides lobatulus, Marseille Jetée/Carry, 4a: dorsal side, 4b: aperture view, 4c: ventral side; 5) Rosalina bradyi, Santa Manza, Corsica, 5a: dorsal side, 5b: ventral side; 6) Rosalina globularis, Marseille Jetée, 6a: dorsal side, 6b: ventral side; 7) Neoconorbina terquemi, Pampelone, 7a: dorsal side, 7b: aperture view, 7c: ventral side. NB: scale bar is $100 \mu \mathrm{m}$.

Plate 4: 1) Elphidium crispum, Grau du Roi, 1a: side view, 1b: aperture view; 2) Elphidium poeyanum $\mathrm{f}$. decipiens, Marseille Jetée, 2a: side view, 2b: aperture view; 3) Elphidium granosum f. lidoense, Beauduc, 3a: side view, 3b: aperture view; 4) Astrononion stelligerum, Fréjus/Toulon Grande Rade, 4a: side view, 4b: aperture view; 5) Ammonia beccarii f. beccarii, Grau du Roi, 5a: dorsal side, 5b: aperture view, 5c: ventral side; 6) Ammonia parkinsoniana f. tepida, Beauduc, 6a: dorsal side, 6b: aperture view, 6c: ventral side; 7) Spirillina sp., Fréjus; 8) Buccella granulata, Agde Est, 8a: dorsal side, 8b: aperture view, 8c: ventral side; 9) Reusella spinulosa, Marseille Jetée. NB: scale bar is $100 \mu \mathrm{m}$.

Supplementary material 2: Number of living (Rose Bengal stained) foraminifera $(>150 \mu \mathrm{m})$ in the first centimetre of sediment standardised for $50 \mathrm{~cm}^{2}$.

Supplementary material 3: Taxonomical list of the major species identified in this study. densities of the major species ( $>5 \%$ ) of the 31 stations (see Table 2 for the meaning of species abbreviations). The percentage of variance explained by the axes is indicated in parenthesis. 
1455

1456 Supplementary material 5: Cluster analyses based on the relative densities of major species $(>5 \%)$ in the 31

1457 stations using paired group algorithm and correlation similarity measures (see Table 2 for the meaning of species 1458 abbreviations). 


\begin{tabular}{|c|c|c|c|c|c|c|c|c|c|c|}
\hline & Station & OPD (mm) & $\begin{array}{c}\text { ALD5/ ALD6 } \\
(\mathrm{cm})\end{array}$ & Depth (m) & $\% \mathrm{OM}$ & $\%<63 \mu \mathrm{m}$ & $\% 63-125 \mu \mathrm{m}$ & $\% 125-250 \mu m$ & $\% 250-500 \mu \mathrm{m}$ & $\%>500 \mu \mathrm{m}$ \\
\hline \multicolumn{11}{|l|}{ Group A } \\
\hline & Grau & 7 & 1.0 & 15 & 3.28 & 67.92 & 25.86 & 6.21 & 0.00 & 0.00 \\
\hline & Toul & - & 1.1 & 43 & 7.52 & 50.90 & 11.59 & 4.84 & 2.82 & 29.85 \\
\hline & Cart & 6 & 1.3 & 10 & 5.91 & 80.80 & 13.07 & 6.14 & 0.00 & 0.00 \\
\hline & Mjet & 14 & 1.4 & 41 & 5.41 & 51.91 & 19.80 & 19.78 & 7.61 & 0.90 \\
\hline & Nice & 12 & 1.4 & 30 & 2.21 & 46.12 & 28.47 & 17.79 & 6.80 & 0.81 \\
\hline & Bduc & - & 1.6 & 14 & 1.68 & 87.52 & 10.75 & 1.73 & 0.00 & 0.00 \\
\hline \multicolumn{11}{|l|}{ Group B } \\
\hline & Colli & - & 1.4 & 23 & 1.37 & 2.89 & 13.86 & 39.90 & 33.74 & 9.62 \\
\hline & AgdE & - & 1.8 & 21 & 1.57 & 8.45 & 27.56 & 56.99 & 6.99 & 0.00 \\
\hline & Maire & - & 2.0 & 40 & 3.31 & 4.82 & 4.26 & 11.22 & 23.28 & 56.42 \\
\hline & Vfran & - & 2.0 & 42 & 3.99 & 14.66 & 12.25 & 18.11 & 22.75 & 32.22 \\
\hline & Leuc & - & 2.2 & 22 & 1.72 & 19.73 & 53.10 & 24.61 & 2.41 & 0.14 \\
\hline & Carry & - & 2.3 & 48 & 3.54 & 26.28 & 14.25 & 17.57 & 17.72 & 24.18 \\
\hline & Ment & - & 2.3 & 51 & 1.73 & 28.26 & 37.50 & 32.75 & 1.49 & 0.00 \\
\hline & Pamp & - & 2.7 & 42 & 2.78 & 19.10 & 6.06 & 11.39 & 23.95 & 39.49 \\
\hline
\end{tabular}




\section{Perforate species}

\section{Name}

Ammonia beccarii f. beccarii

Asterigerinata mamilla

Astrononion stelligerum

Buccella granulata

Bulimina aculeata

Cancris auriculus

Cibicides lobatulus

Elphidium crispum

Elphidium granosum

Elphidium poeyanum f. decipiens

Hanzawaia boueana

Neoconorbina terquemi

Nonion depressulum

Nonion scaphum

Nonionella turgida

Planorbulina mediterranensis

Rectuvigerina phlegeri

Rosalina globularis

Spirillina sp.

Valvulineria bradyana

\section{Porcelaneous species}

Abbrev.

Abecc

Amami

Astel

Bgran

Bacul

Cauri

Cloba

Ecris

Egran

Epoey

Hboue

Nterq

Ndepres

Nscap

Nturg

Pmedit

Rphle

Rglob

Spiril

\section{Name}

Adelosina longirostra

Biloculinella irregularis

Quinqueloculina aspera

Quinqueloculina bosciana

Quinqueloculina costata

Quinqueloculina seminula

Sigmoilina grata

Triloculina trigonula

Vbrad

\section{Agglutinated species}

Name

Abbrev.

Abbrev.

Along

Birreg

Ammoscalaria pseudospiralis Apseudo

Eggerella scabra Escab

Lagenammina sp. a LagenamA

Lagenammina sp. b LagenamB

Rscot

Qcost

Qsemi

Sgrata

Psamosphaera fusca

Pfusc

Reophax fusiformis

Reophax micaceus Rmica

Reophax scorpiurus Rscorp

Reophax subfusiformis Rsubfus

Textularia agglutinans Taggl

Textularia sagittula Tsagit 


\begin{tabular}{|c|c|c|c|c|}
\hline$\overline{\text { Stations }}$ & $\begin{array}{c}\text { \%TS } \boldsymbol{x} \\
\% \text { tolerant species, } \\
\text { station } x\end{array}$ & $\begin{array}{c}\%<63 \mu \mathrm{m} \\
\%<63 \mu \mathrm{m} \text { particles }\end{array}$ & $\begin{array}{c}\% \text { TSref } \\
\% \text { tolerant species, } \\
\text { theoretical reference } \\
\text { conditions }\end{array}$ & $\begin{array}{c}\text { \%TSstd } \\
\text { Standardised \% } \\
\text { tolerant species }\end{array}$ \\
\hline Cerb & 1.90 & 4.56 & 0.3 & 1.6 \\
\hline Colli & 2.67 & 2.89 & 0.3 & 2.4 \\
\hline Leuc & 46.28 & 19.73 & 1.1 & 45.7 \\
\hline Gruis & 11.11 & 42.36 & 3.2 & 8.2 \\
\hline AgdW & 2.21 & 18.70 & 1.0 & 1.2 \\
\hline $\mathrm{AgdE}$ & 2.42 & 8.45 & 0.5 & 1.9 \\
\hline Sete & 6.54 & 30.35 & 1.9 & 4.7 \\
\hline Grau & 7.07 & 67.92 & 8.0 & -1.1 \\
\hline Bduc & 17.79 & 87.52 & 15.3 & 2.9 \\
\hline Fara & 0.00 & 6.16 & 0.4 & -0.4 \\
\hline Cart & 35.06 & 80.80 & 12.3 & 25.9 \\
\hline Fos & 24.93 & 73.57 & 9.7 & 16.9 \\
\hline Carry & 34.77 & 26.28 & 1.6 & 33.7 \\
\hline Mrade & 16.13 & & & \\
\hline Mjet & 39.84 & 51.91 & 4.6 & 37.0 \\
\hline Plane & 9.26 & 13.18 & 0.7 & 8.6 \\
\hline Maire & 11.11 & 4.82 & 0.3 & 10.8 \\
\hline Ccan & 0.36 & 13.25 & 0.7 & -0.4 \\
\hline Embi & 5.10 & 28.30 & 1.7 & 3.4 \\
\hline Toul & 22.47 & 50.90 & 4.4 & 18.9 \\
\hline Porq & 0.00 & 10.83 & 0.6 & -0.6 \\
\hline Lav & 2.33 & 25.56 & 1.5 & 0.8 \\
\hline Levan & 5.08 & 6.47 & 0.4 & 4.7 \\
\hline Pamp & 8.85 & 19.10 & 1.1 & 7.9 \\
\hline Fréj & 2.82 & 17.35 & 1.0 & 1.9 \\
\hline Antib2 & 0.78 & 36.56 & 2.5 & -1.8 \\
\hline AntibN & 0.00 & 1.62 & 0.2 & -0.2 \\
\hline Nice & 3.00 & 46.12 & 3.7 & -0.7 \\
\hline Vfran & 6.93 & 14.66 & 0.8 & 6.2 \\
\hline Monac & 19.51 & 56.83 & 5.5 & 14.9 \\
\hline Ment & 21.96 & 28.26 & 1.7 & 20.6 \\
\hline
\end{tabular}




\section{Figureny}

\section{France}

Bay of Biscay

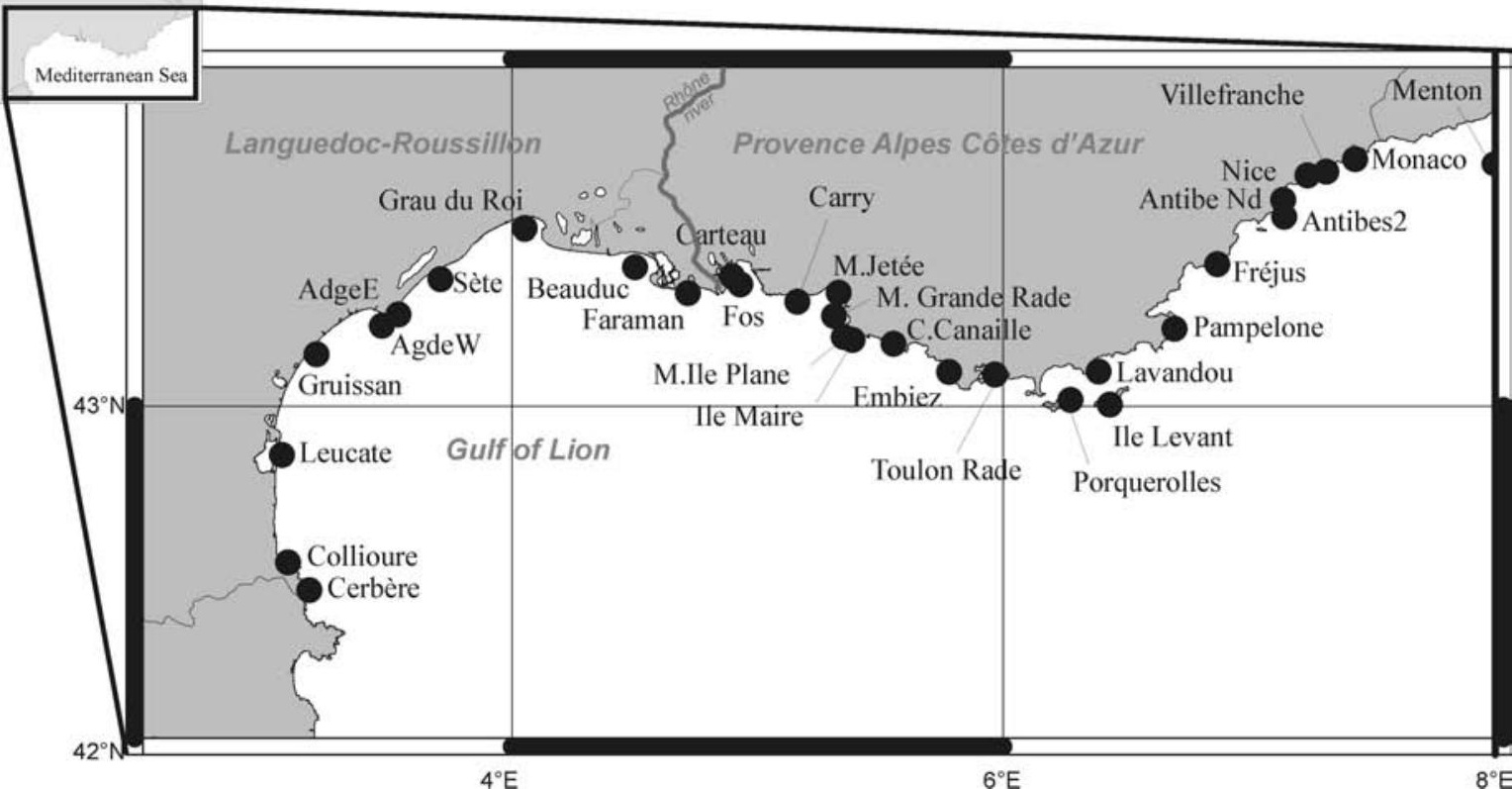


$\underset{10}{\text { Figưre } 2}$ a)

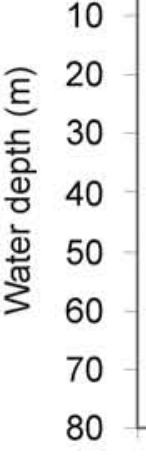

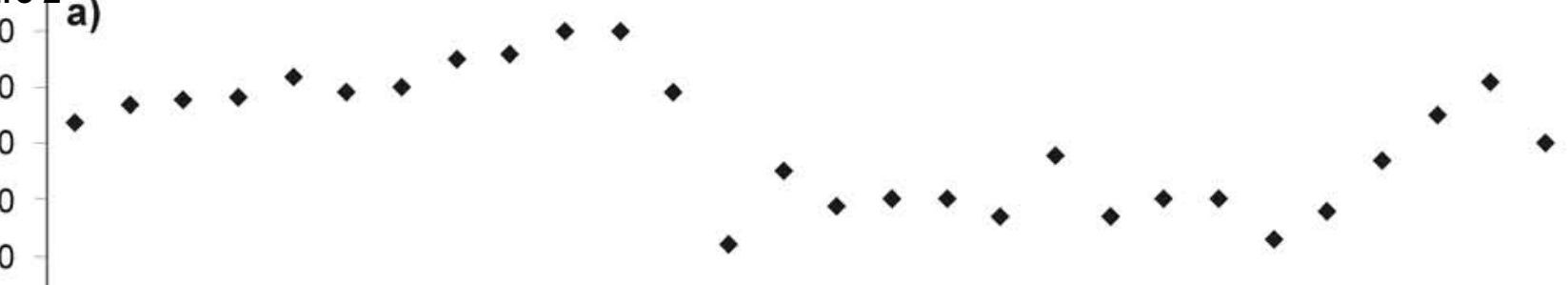

\begin{tabular}{l|l|}
8 & b) \\
7 &
\end{tabular}

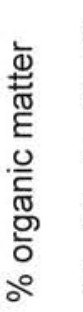

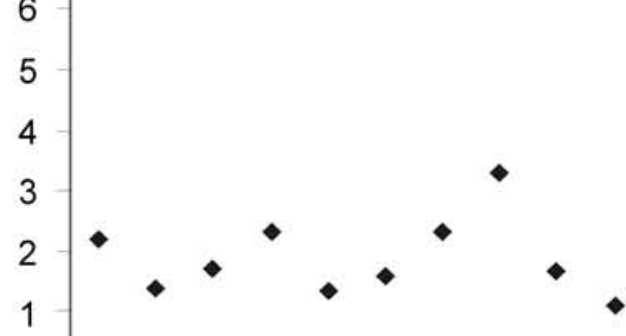

0

n.d. n.d.

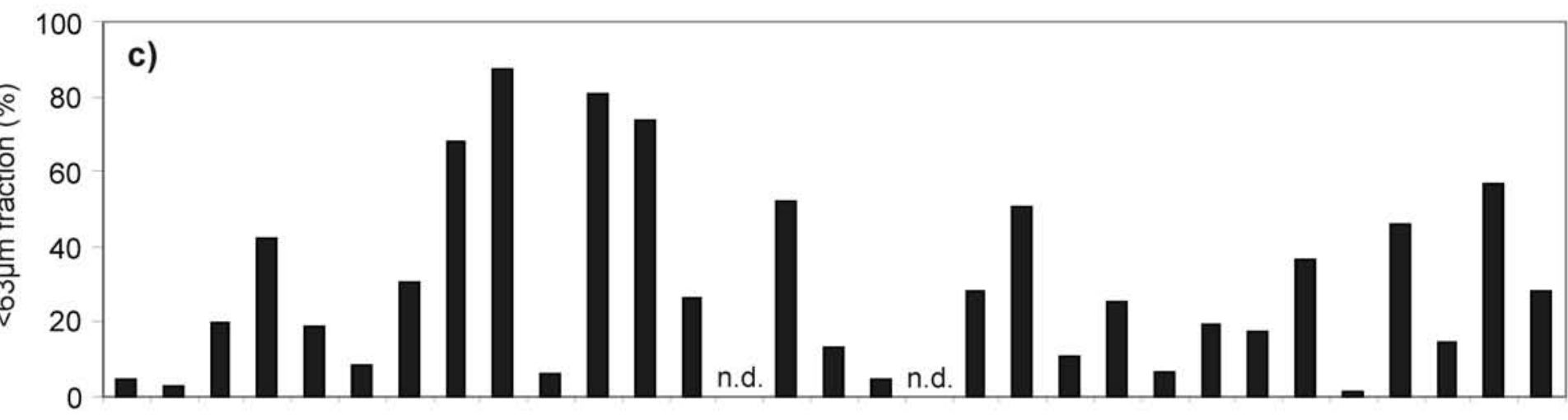

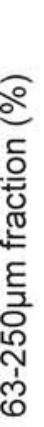

00

d)
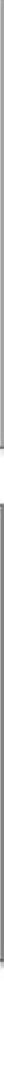


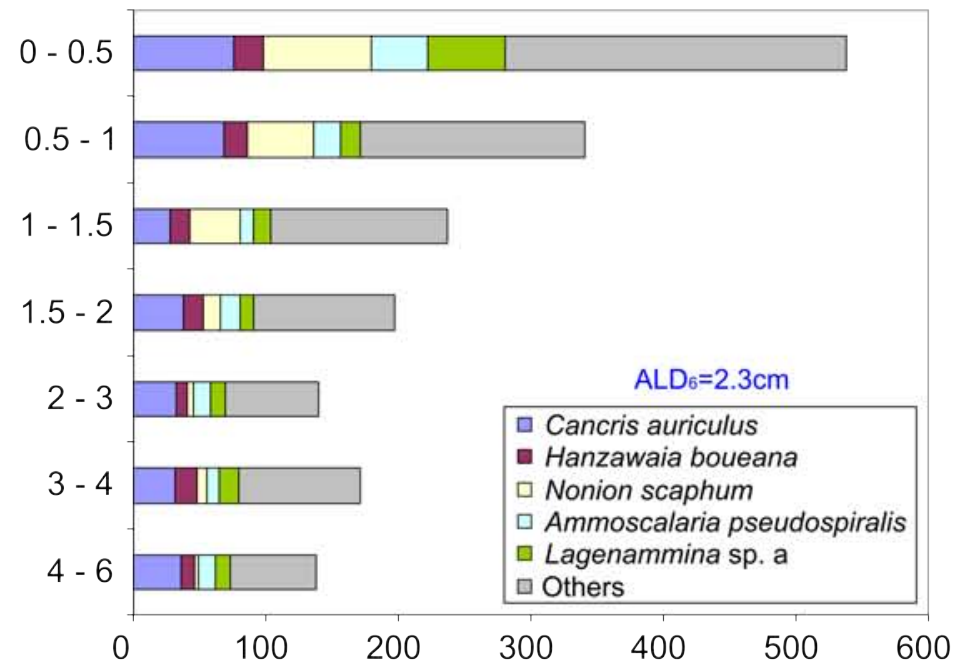

Pampelone
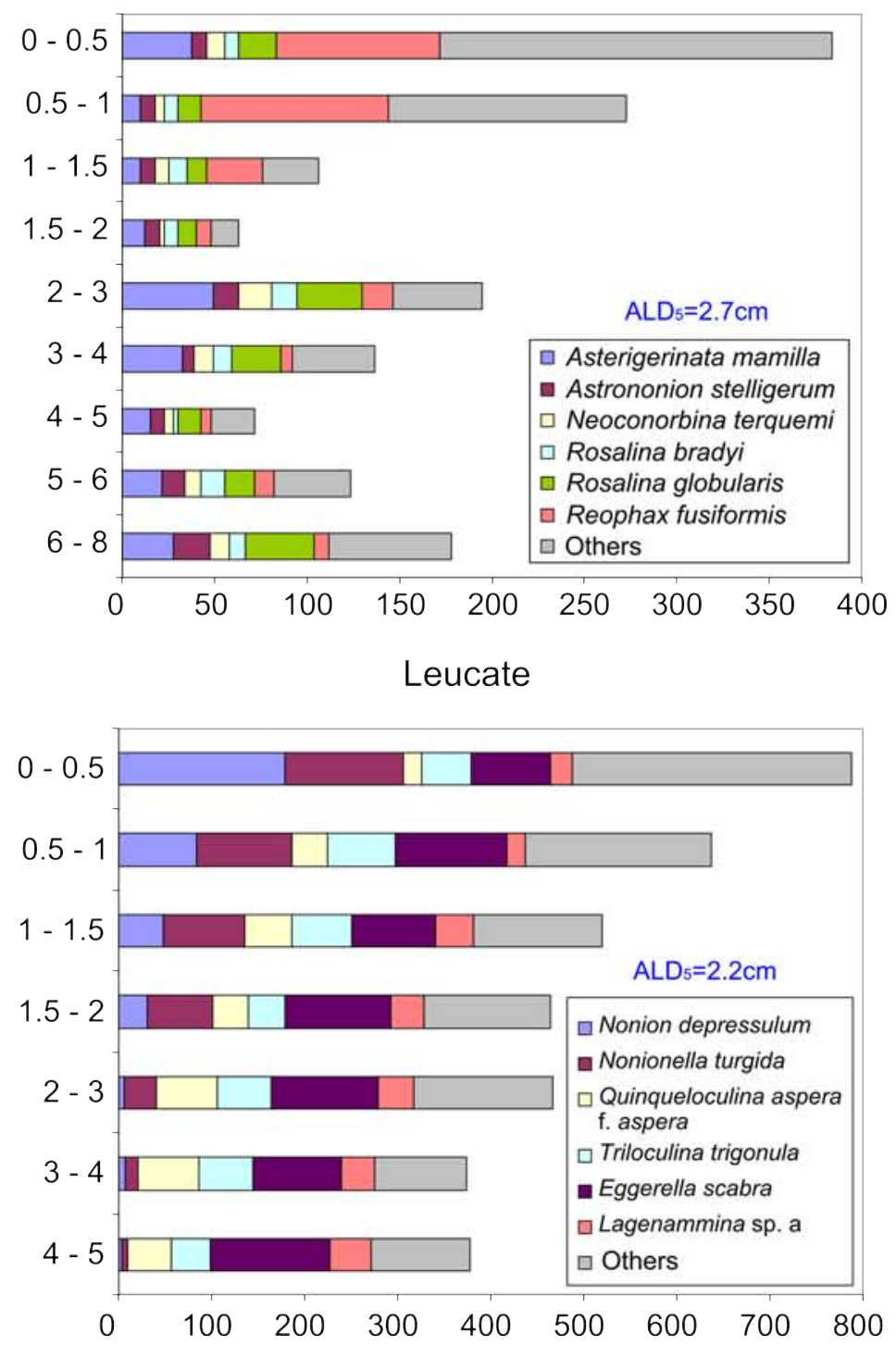

Absolute densities (standardised for $50 \mathrm{~cm}^{3}$ )
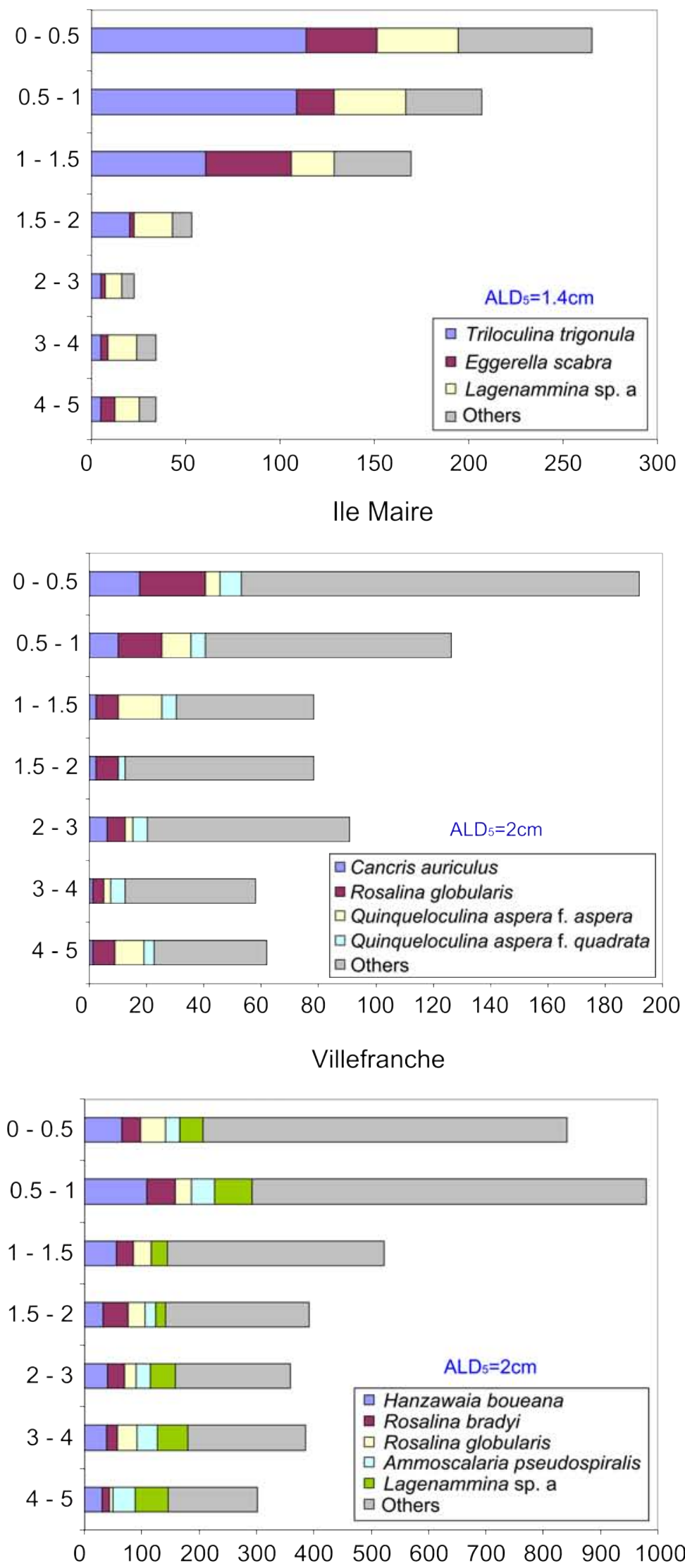

Absolute densities (standardised for $50 \mathrm{~cm}^{3}$ ) 


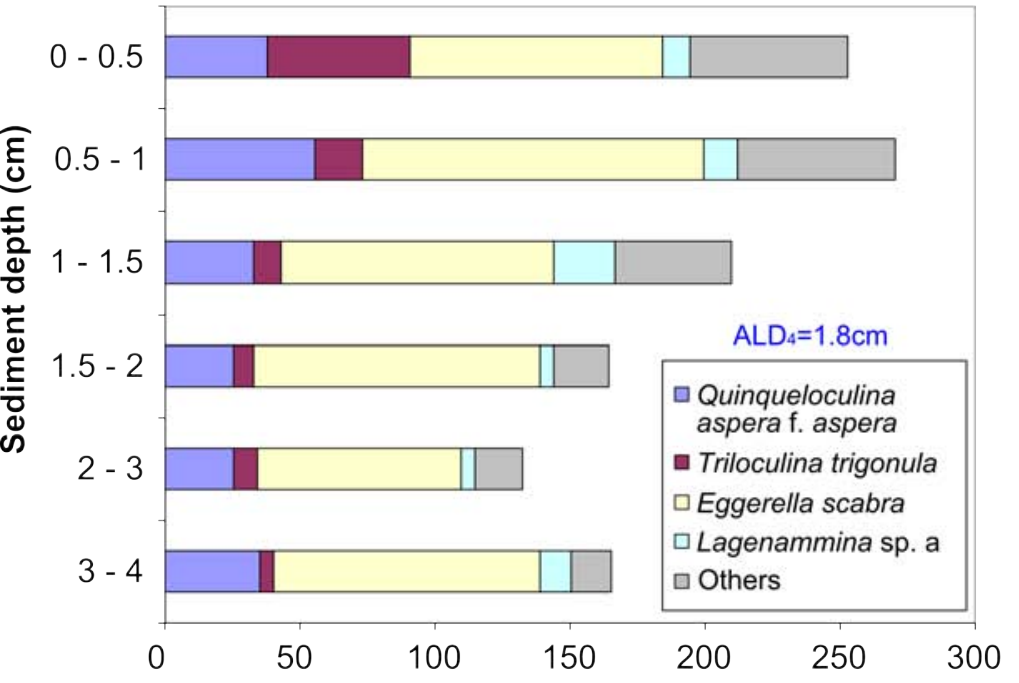

Absolute densities (standardised for $50 \mathrm{~cm}^{3}$ )

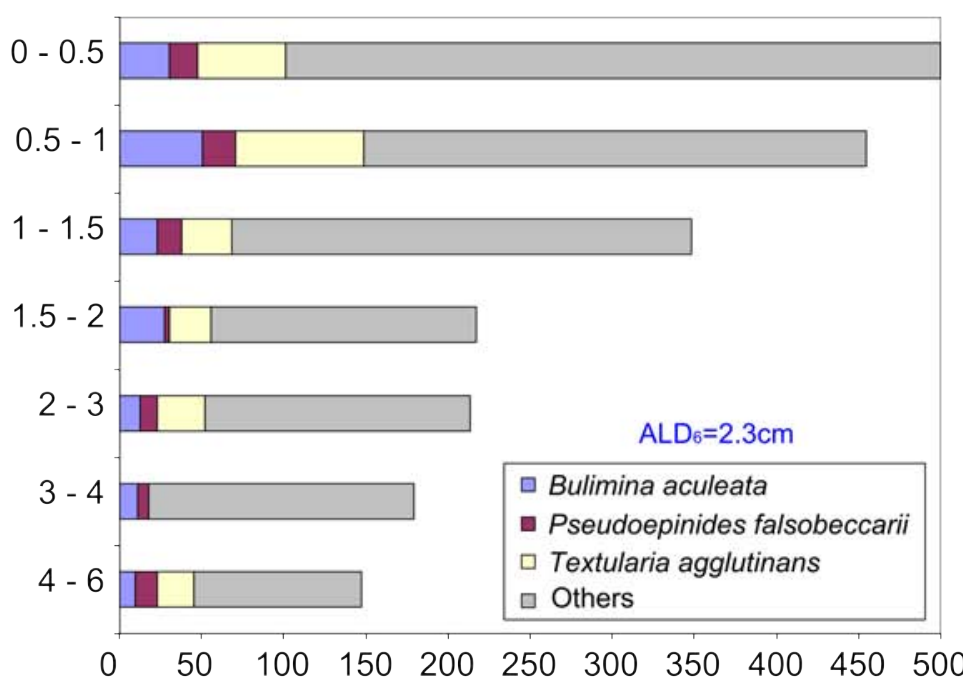

Absolute densities (standardised for $50 \mathrm{~cm}^{3}$ ) 


\section{Figure 7}

- \% agglutinated species

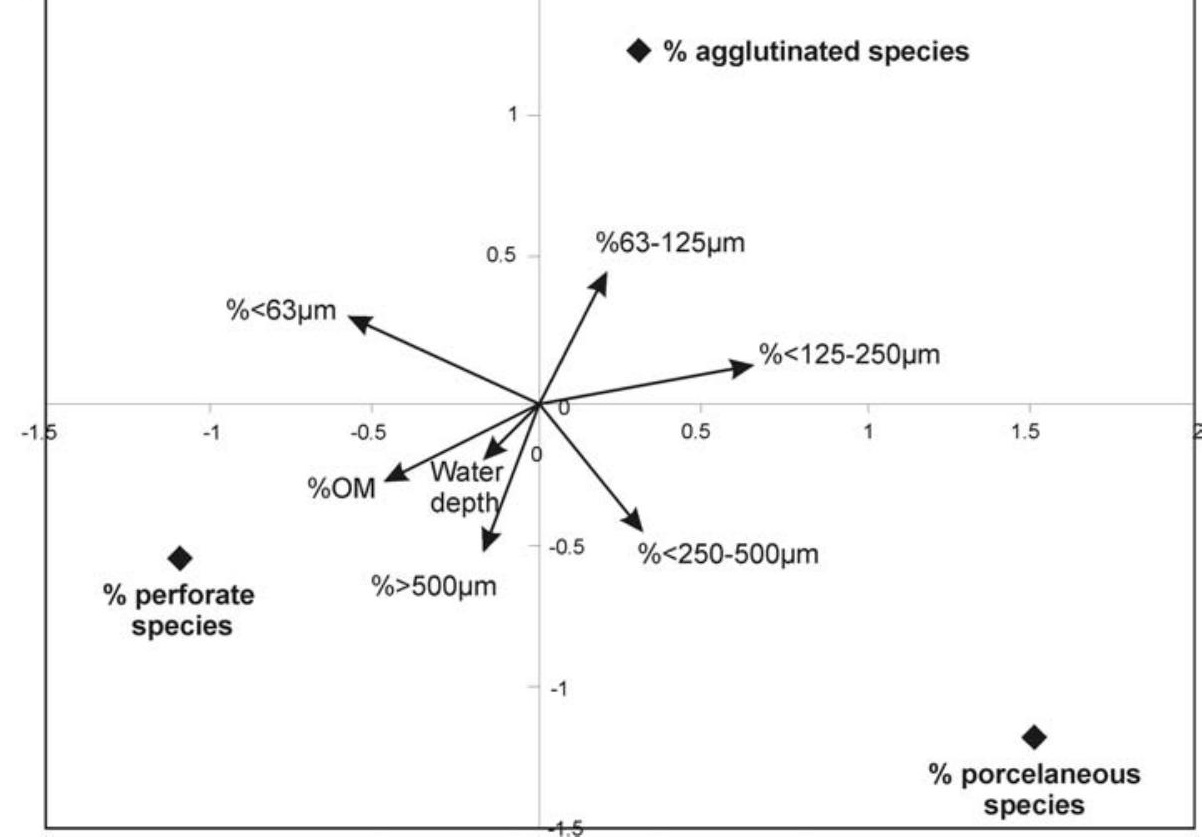


Figure 8 a)

$50-$

$\mathscr{\infty}$

U $40-$

.

$\frac{2}{2}$

(1) 20

$10-$

$$
0
$$
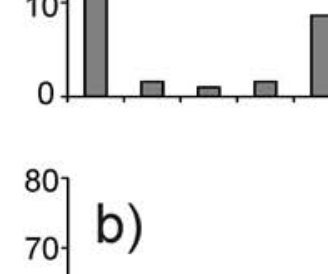

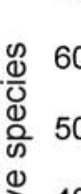

:

¿ 30

$\therefore$

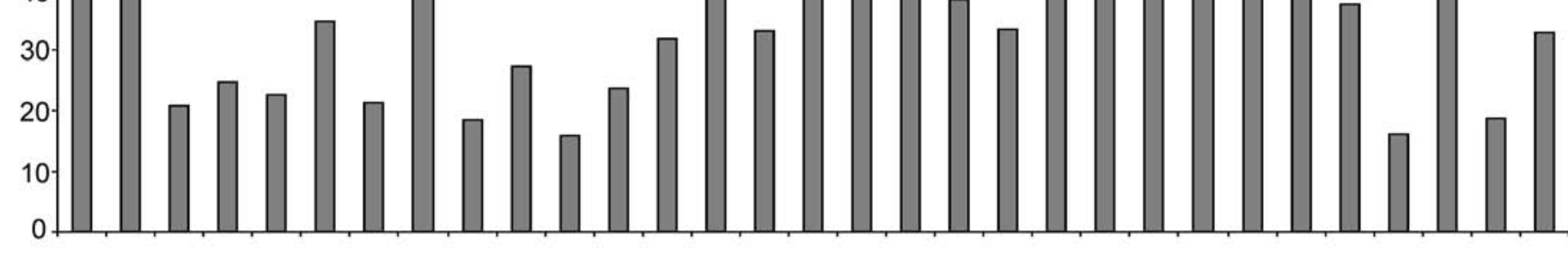

c)

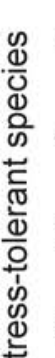

10

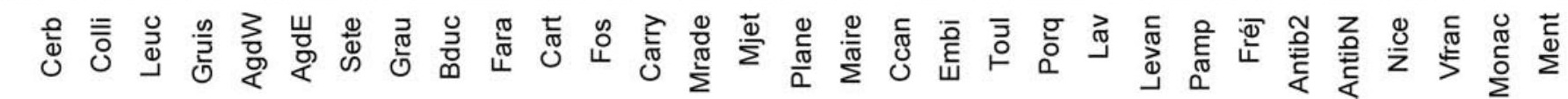




\section{Figuree 9 iphytic species}

$\Delta$

Water depth

$\% O M$

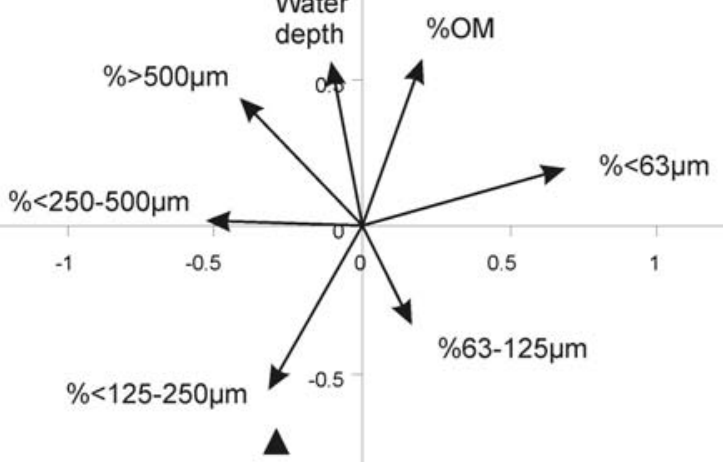

$\%$ tolerant species

$\Delta$

$\%$ sensitive species 


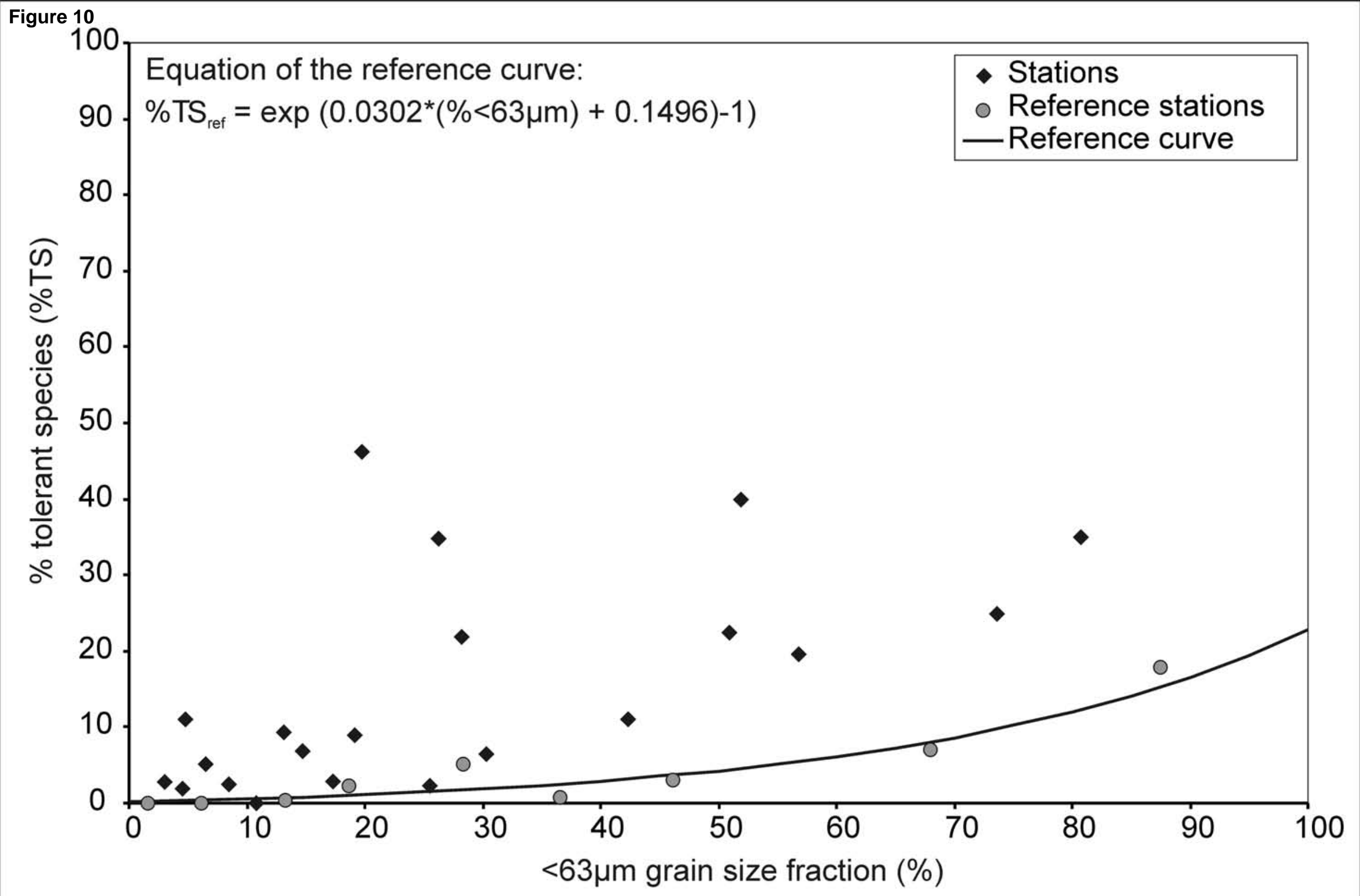


Appendix A: Localisation (WGS84) and water depth of the stations. The sediment layers analysed for living foraminiferal faunas are indicated.

\begin{tabular}{|c|c|c|c|c|c|c|}
\hline Station & Station abbr. & Longitude $\left({ }^{\circ} \mathrm{E}\right)$ & Latitude ( $\left.{ }^{\circ} \mathrm{N}\right)$ & Water depth $(\mathrm{m})$ & $\begin{array}{l}\text { Sediment interval studied }(\mathrm{cm}), \\
\text { living fauna }\end{array}$ & $\begin{array}{l}\text { Oxygen } \\
\text { profiles }\end{array}$ \\
\hline Cerbère & Cerb & $3^{\circ} 10^{\prime} 21^{\prime \prime}$ & $42^{\circ} 26^{\prime} 43^{\prime \prime}$ & 26 & $0-1$ & \\
\hline Collioure & Colli & $3^{\circ} 05^{\prime} 22^{\prime \prime}$ & $42^{\circ} 31^{\prime} 54^{\prime \prime}$ & 23 & $0-5$ & \\
\hline Leucate & Leuc & $3^{\circ} 04^{\prime} 00^{\prime \prime}$ & $42^{\circ} 51^{\prime} 09^{\prime \prime}$ & 22 & $0-5$ & \\
\hline Gruissan & Gruis & 312'16" & $43^{\circ} 09^{\prime} 12^{\prime \prime}$ & 21.5 & $0-1$ & \\
\hline Agde Ouest & AgdW & $3^{\circ} 28^{\prime} 16^{\prime \prime}$ & $43^{\circ} 14 ' 21 "$ & 18 & $0-1$ & \\
\hline Agde Est & AgdE & $3^{\circ} 32^{\prime} 23^{\prime \prime}$ & $43^{\circ} 16^{\prime} 17^{\prime \prime}$ & 21 & $0-4$ & \\
\hline Sète & Sete & $3^{\circ} 42^{\prime} 41^{\prime \prime}$ & $43^{\circ} 22^{\prime} 38^{\prime \prime}$ & 20 & $0-1$ & \\
\hline Grau du Roi & Grau & $4^{\circ} 03^{\prime} 12^{\prime \prime}$ & $43^{\circ} 31^{\prime} 34^{\prime \prime}$ & 15 & $0-10$ & $\mathrm{x}$ \\
\hline Beauduc & Bduc & $4^{\circ} 30^{\prime} 08^{\prime \prime}$ & $43^{\circ} 2484^{\prime \prime \prime}$ & 14 & $0-5$ & \\
\hline Faraman & Fara & $4^{\circ} 43^{\prime} 13^{\prime \prime}$ & $43^{\circ} 20^{\prime} 00^{\prime \prime}$ & 10 & $0-1$ & \\
\hline Carteau & Cart & $4^{\circ} 53^{\prime} 44^{\prime \prime}$ & $43^{\circ} 23^{\prime} 08^{\prime \prime}$ & 10 & $0-10$ & $\mathrm{X}$ \\
\hline Fos & Fos & $4^{\circ} 55^{\prime} 46^{\prime \prime}$ & $43^{\circ} 21^{\prime} 38^{\prime \prime}$ & 20.8 & $0-1$ & $\mathrm{X}$ \\
\hline Carry & Carry & $5^{\circ} 09^{\prime} 38^{\prime \prime}$ & $43^{\circ} 18^{\prime} 40^{\prime \prime}$ & 48 & $0-6$ & \\
\hline Marseille Grande Rade & Mrade & $5^{\circ} 18^{\prime} 28 "$ & $43^{\circ} 16^{\prime} 10^{\prime \prime}$ & 35 & $0-1$ & \\
\hline Marseille Jetée & Mjet & 519'41" & $43^{\circ} 20^{\prime} 15^{\prime \prime}$ & 41 & $0-6$ & $\mathrm{X}$ \\
\hline Marseille-Ile Plane & Plane & $5^{\circ} 23^{\prime} 02^{\prime \prime}$ & $43^{\circ} 11^{\prime} 41^{\prime \prime}$ & 40 & $0-1$ & \\
\hline Ile Maire & Maire & $5^{\circ} 20^{\prime} 50^{\prime \prime}$ & $43^{\circ} 12^{\prime} 16^{\prime \prime}$ & 40 & $0-5$ & \\
\hline Cap Canaille & Ccan & 53'11" & $43^{\circ} 11^{\prime} 07^{\prime \prime}$ & 43 & $0-1$ & \\
\hline Ile Embiez & Embi & $5^{\circ} 46^{\prime} 47^{\prime \prime}$ & $43^{\circ} 06^{\prime} 08^{\prime \prime}$ & 32 & $0-1$ & \\
\hline Toulon Gde Rade & Toul & $5^{\circ} 57^{\prime} 54^{\prime \prime}$ & $43^{\circ} 05^{\prime} 34^{\prime \prime}$ & 43 & $0-3$ & \\
\hline Porquerolles & Porq & 6¹6'28" & $43^{\circ} 01^{\prime} 08^{\prime \prime}$ & 40 & $0-1$ & \\
\hline Lavandou & Lav & $6^{\circ} 23^{\prime} 13^{\prime \prime}$ & $43^{\circ} 06^{\prime} 08^{\prime \prime}$ & 40 & $0-1$ & \\
\hline Ile Levant & Levan & $6^{\circ} 25^{\prime} 60^{\prime \prime}$ & $43^{\circ} 00^{\prime} 13^{\prime \prime}$ & 47 & $0-1$ & \\
\hline Pampelone & Pamp & $6^{\circ} 41^{\prime} 44^{\prime \prime}$ & $43^{\circ} 13^{\prime} 44^{\prime \prime}$ & 42 & $0-8$ & \\
\hline Fréjus & Fréj & $6^{\circ} 52^{\prime} 07^{\prime \prime}$ & $43^{\circ} 25^{\prime} 20^{\prime \prime}$ & 33 & $0-1$ & $\mathrm{X}$ \\
\hline Antibes 2 & Antib2 & $7^{\circ} 08^{\prime} 29^{\prime \prime}$ & $43^{\circ} 33^{\prime} 34^{\prime \prime}$ & 25 & $0-1$ & $\mathrm{x}$ \\
\hline Antibes Nord & AntibN & $7^{\circ} 08^{\prime} 07^{\prime \prime}$ & $43^{\circ} 36^{\prime} 47^{\prime \prime}$ & 19 & $0-1$ & \\
\hline Nice Ville & Nice & 714'08" & $43^{\circ} 40^{\prime} 51^{\prime \prime}$ & 30 & $0-10$ & $x$ \\
\hline Villefranche & Vfran & 718'40" & $43^{\circ} 41^{\prime} 35^{\prime \prime}$ & 42 & $0-5$ & \\
\hline Monaco 2 & Monac & $7^{\circ} 25^{\prime} 47^{\prime \prime}$ & $43^{\circ} 43^{\prime} 43^{\prime \prime}$ & 69 & $0-1$ & $x$ \\
\hline Menton & Ment & $7^{\circ} 59^{\prime} 41^{\prime \prime}$ & $43^{\circ} 45^{\prime} 21^{\prime \prime}$ & 51 & $0-6$ & \\
\hline
\end{tabular}


Appendix B: Environmental parameters and faunal parameters (considering foraminiferal faunas from the $>150 \mu \mathrm{m}$ size fraction and 0 - $1 \mathrm{~cm}$ sediment interval) calculated for the 31 stations analysed in this study (presented from West to East).

Station

Environmental parameters

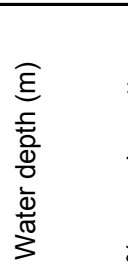

Grain size fraction of the sediment

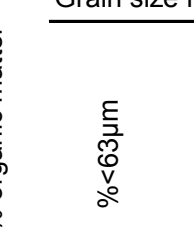

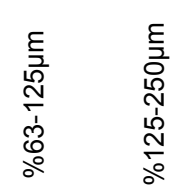

Foraminiferal parameters

\begin{tabular}{|c|c|c|c|c|c|c|c|c|c|c|c|c|c|c|c|c|c|c|}
\hline Cerb & 26 & 2.20 & 4.56 & 0.47 & 26.30 & 55.53 & 13.14 & 1.90 & 44.76 & 14.29 & 28.57 & 29.52 & 41.90 & 132 & 32 & 3.02 & 0.87 & 21.37 \\
\hline Colli & 23 & 1.37 & 2.89 & 13.86 & 39.90 & 33.74 & 9.62 & 2.67 & 62.03 & 1.60 & 8.56 & 57.75 & 33.69 & 237 & 26 & 1.96 & 0.60 & 12.29 \\
\hline Leuc & 22 & 1.72 & 19.73 & 53.10 & 24.61 & 2.41 & 0.14 & 46.28 & 20.92 & 0.89 & 46.81 & 18.62 & 34.57 & 709 & 36 & 2.71 & 0.76 & 16.52 \\
\hline Gruis & 21.5 & 2.30 & 42.36 & 35.64 & 20.34 & 1.18 & 0.49 & 11.11 & 24.84 & 1.63 & 18.30 & 20.92 & 60.78 & 301 & 24 & 2.26 & 0.71 & 13.33 \\
\hline AgdW & 18 & 1.36 & 18.70 & 39.71 & 40.63 & 0.97 & 0.00 & 2.21 & 22.55 & 8.58 & 28.92 & 13.73 & 57.35 & 516 & 32 & 2.56 & 0.74 & 15.92 \\
\hline Sete & 20 & 2.30 & 30.35 & 31.39 & 30.66 & 5.67 & 1.93 & 6.54 & 21.25 & 4.63 & 28.61 & 14.99 & 56.40 & 461 & 37 & 2.59 & 0.72 & 16.88 \\
\hline Grau & 15 & 3.28 & 67.92 & 25.86 & 6.21 & 0.00 & 0.00 & 7.07 & 60.51 & 0.06 & 78.74 & 3.02 & 18.24 & 2091 & 33 & 1.86 & 0.53 & 11.55 \\
\hline Bduc & 14 & 1.68 & 87.52 & 10.75 & 1.73 & 0.00 & 0.00 & 17.79 & 18.40 & 0.00 & 49.08 & 2.45 & 48.47 & 209 & 21 & 2.62 & 0.86 & 15.29 \\
\hline Fara & 10 & 1.08 & 6.16 & 52.35 & 40.01 & 1.49 & 0.00 & 0.00 & 27.27 & 0.00 & 31.82 & 27.27 & 40.91 & 22 & 5 & 1.34 & 0.83 & n.d. \\
\hline Cart & 10 & 5.91 & 80.80 & 13.07 & 6.14 & 0.00 & 0.00 & 35.06 & 16.02 & 1.30 & 49.35 & 14.29 & 36.36 & 287 & 28 & 2.51 & 0.75 & 14.28 \\
\hline Carry & 48 & 3.54 & 26.28 & 14.25 & 17.57 & 17.72 & 24.18 & 34.77 & 31.90 & 22.99 & 62.36 & 7.76 & 29.89 & 439 & 46 & 3.07 & 0.80 & 20.67 \\
\hline Mrade & 35 & n.d. & n.d. & n.d. & n.d. & n.d. & n.d. & 16.13 & 45.16 & 24.19 & 61.29 & 14.52 & 24.19 & 81 & 23 & 3.01 & 0.96 & 20.65 \\
\hline Mjet & 41 & 5.41 & 51.91 & 19.80 & 19.78 & 7.61 & 0.90 & 39.84 & 33.13 & 20.73 & 68.50 & 7.52 & 23.98 & 620 & 49 & 3.14 & 0.81 & 21.58 \\
\hline Plane & 40 & 3.34 & 13.18 & 11.24 & 23.55 & 26.40 & 25.63 & 9.26 & 57.41 & 38.89 & 60.19 & 13.89 & 25.93 & 137 & 32 & 3.13 & 0.90 & 21.82 \\
\hline Maire & 40 & 3.31 & 4.82 & 4.26 & 11.22 & 23.28 & 56.42 & 11.11 & 57.94 & 26.19 & 46.03 & 30.16 & 23.81 & 159 & 39 & 3.27 & 0.89 & 24.30 \\
\hline Ccan & 43 & n.d. & 13.25 & 39.96 & 35.56 & 7.25 & 3.97 & 0.36 & 52.14 & 7.14 & 20.00 & 40.71 & 39.29 & 354 & 38 & 3.02 & 0.83 & 19.66 \\
\hline Embi & 32 & 1.87 & 28.30 & 50.41 & 16.44 & 1.98 & 2.87 & 5.10 & 38.22 & 8.92 & 24.84 & 22.29 & 52.87 & 199 & 32 & 2.93 & 0.84 & 19.38 \\
\hline Toul & 43 & 7.52 & 50.90 & 11.59 & 4.84 & 2.82 & 29.85 & 22.47 & 33.33 & 16.85 & 52.43 & 12.36 & 35.21 & 337 & 48 & 3.46 & 0.89 & 26.05 \\
\hline Porq & 40 & 2.84 & 10.83 & 3.24 & 4.78 & 13.83 & 67.31 & 0.00 & 76.19 & 54.76 & 71.43 & 19.05 & 9.52 & 51 & 19 & 2.48 & 0.84 & 18.75 \\
\hline Lav & 40 & 3.78 & 25.56 & 13.16 & 19.98 & 25.89 & 15.41 & 2.33 & 62.79 & 27.91 & 50.00 & 28.57 & 21.43 & 43 & 26 & 3.10 & 0.95 & n.d. \\
\hline Pamp & 42 & 2.78 & 19.10 & 6.06 & 11.39 & 23.95 & 39.49 & 8.85 & 46.15 & 18.85 & 36.43 & 25.19 & 38.37 & 331 & 39 & 2.85 & 0.78 & 19.52 \\
\hline Fréj & 33 & 4.04 & 17.35 & 22.82 & 33.57 & 20.25 & 6.02 & 2.82 & 68.75 & 16.53 & 33.67 & 42.94 & 23.39 & 627 & 62 & 3.52 & 0.85 & 25.72 \\
\hline Antib2 & 25 & 4.13 & 36.56 & 26.20 & 16.04 & 12.91 & 8.29 & 0.78 & 54.09 & 16.93 & 28.79 & 29.96 & 41.25 & 648 & 56 & 3.21 & 0.80 & 22.88 \\
\hline AntibN & 19 & 1.04 & 1.62 & 22.75 & 59.25 & 16.37 & 0.00 & 0.00 & 37.39 & 0.00 & 18.49 & 36.97 & 44.54 & 302 & 26 & 2.45 & 0.75 & 15.22 \\
\hline Nice & 30 & 2.21 & 46.12 & 28.47 & 17.79 & 6.80 & 0.81 & 3.00 & 16.10 & 0.00 & 13.48 & 15.73 & 70.79 & 338 & 32 & 2.22 & 0.64 & 14.74 \\
\hline Vfran & 42 & 3.99 & 14.66 & 12.25 & 18.11 & 22.75 & 32.22 & 6.93 & 51.80 & 26.98 & 41.99 & 20.06 & 37.95 & 874 & 52 & 3.41 & 0.86 & 24.19 \\
\hline Monac & 69 & 3.72 & 56.83 & 20.53 & 11.39 & 4.92 & 6.33 & 19.51 & 18.76 & 6.57 & 41.09 & 10.32 & 48.59 & 664 & 73 & 3.71 & 0.87 & 27.98 \\
\hline Ment & 51 & 1.73 & 28.26 & 37.50 & 32.75 & 1.49 & 0.00 & 21.96 & 32.80 & 8.99 & 36.62 & 21.56 & 41.82 & 486 & 61 & 3.48 & 0.85 & 25.59 \\
\hline
\end{tabular}

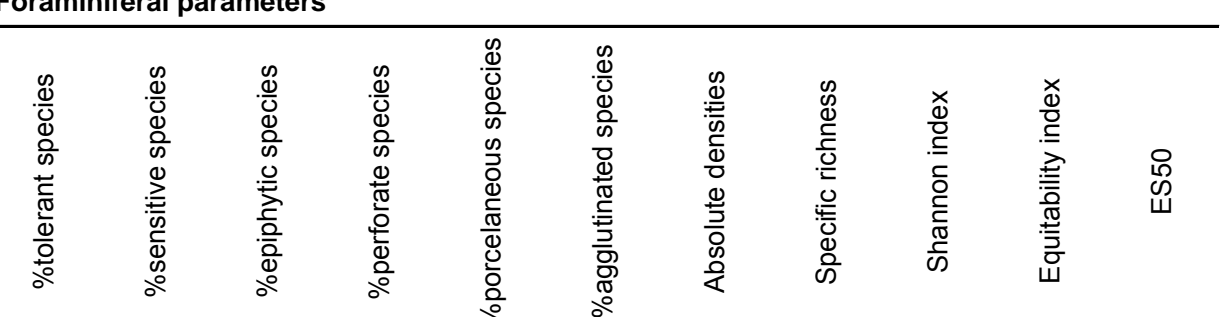


Appendix C: Linear correlations between environmental and faunal parameters (upper right triangle shows $p$ values and lower left triangle shows $r$ values) considering foraminiferal faunas from the $>150 \mu \mathrm{m}$ size fraction and $0-1 \mathrm{~cm}$ sediment interval.

\begin{tabular}{|c|c|c|c|c|c|c|c|c|c|c|c|c|c|c|c|c|c|c|c|}
\hline & \multicolumn{7}{|c|}{ Environmental parameters } & \multicolumn{12}{|c|}{ Foraminiferal parameters } \\
\hline & 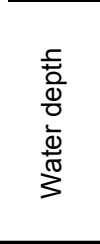 & 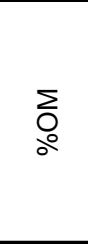 & $\begin{array}{c}\frac{E}{3} \\
\text { O } \\
0 \\
0 \\
0\end{array}$ & 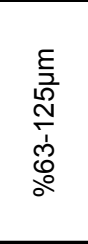 & 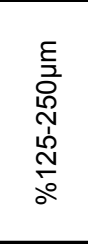 & 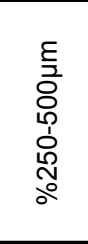 & 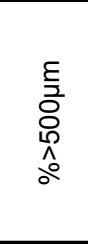 & $\begin{array}{l}\frac{\dot{0}}{0} \\
\frac{0}{\mathbb{N}} \\
\frac{\tilde{w}}{\omega} \\
\frac{0}{0} \\
\frac{0}{0}\end{array}$ & 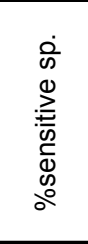 & 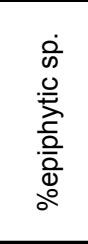 & $\begin{array}{l}\frac{0}{0} \\
0 \\
0 \\
\frac{\pi}{0} \\
\frac{0}{0} \\
\frac{0}{0} \\
\frac{0}{0}\end{array}$ & 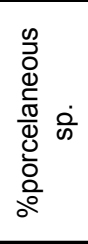 & 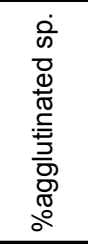 & 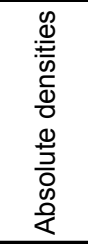 & 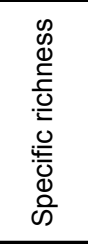 & 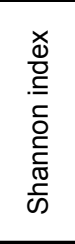 & 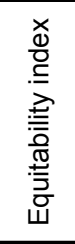 & $\begin{array}{l}\text { 员 } \\
\text { ய }\end{array}$ & 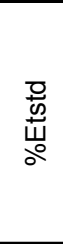 \\
\hline \multicolumn{20}{|c|}{ Environmental parameters } \\
\hline Water depth & & 0.07 & 0.42 & 0.08 & 0.15 & 0.16 & 0.01 & 0.45 & 0.22 & 0.00 & 0.27 & 0.80 & 0.22 & 0.72 & 0.00 & 0.00 & 0.00 & 0.00 & 0.21 \\
\hline$\% \mathrm{OM}$ & 0.34 & & 0.02 & 0.02 & 0.00 & 0.83 & 0.18 & 0.03 & 0.59 & 0.07 & 0.01 & 0.11 & 0.03 & 0.39 & 0.01 & 0.00 & 0.10 & 0.01 & 0.05 \\
\hline$\%<63 \mu \mathrm{m}$ & -0.16 & 0.42 & & 0.87 & 0.00 & 0.00 & 0.04 & 0.01 & 0.01 & 0.07 & 0.02 & 0.00 & 0.66 & 0.06 & 0.39 & 0.80 & 0.47 & 0.51 & 0.17 \\
\hline$\% 63-125 \mu \mathrm{m}$ & -0.33 & -0.42 & -0.03 & & 0.03 & 0.00 & 0.00 & 0.75 & 0.02 & 0.01 & 0.08 & 0.85 & 0.01 & 0.36 & 0.61 & 0.07 & 0.15 & 0.22 & 0.60 \\
\hline$\% 125-250 \mu \mathrm{m}$ & -0.27 & -0.56 & -0.60 & 0.41 & & 0.61 & 0.03 & 0.07 & 0.84 & 0.11 & 0.00 & 0.00 & 0.09 & 0.40 & 0.28 & 0.08 & 0.18 & 0.17 & 0.28 \\
\hline$\% 250-500 \mu \mathrm{m}$ & 0.27 & -0.04 & -0.59 & -0.62 & 0.10 & & 0.01 & 0.06 & 0.00 & 0.03 & 0.46 & 0.00 & 0.10 & 0.11 & 0.98 & 0.22 & 0.16 & 0.22 & 0.21 \\
\hline$\%>500 \mu \mathrm{m}$ & 0.50 & 0.25 & -0.39 & -0.63 & -0.39 & 0.46 & & 0.39 & 0.00 & 0.00 & 0.10 & 0.54 & 0.00 & 0.16 & 0.93 & 0.11 & 0.03 & 0.04 & 0.67 \\
\hline \multicolumn{20}{|c|}{ Foraminiferal parameters } \\
\hline \%tolerant sp. & 0.15 & 0.40 & 0.48 & 0.06 & -0.34 & -0.35 & -0.17 & & 0.01 & 0.55 & 0.01 & 0.00 & 0.37 & 0.40 & 0.10 & 0.14 & 0.68 & 0.55 & 0.00 \\
\hline \%sensitive sp. & 0.23 & 0.10 & -0.49 & -0.44 & -0.04 & 0.59 & 0.60 & -0.48 & & 0.00 & 0.33 & 0.01 & 0.00 & 0.78 & 0.92 & 0.44 & 0.39 & 0.28 & 0.03 \\
\hline \%epiphytic sp. & 0.53 & 0.34 & -0.34 & -0.50 & -0.30 & 0.40 & 0.80 & -0.12 & 0.65 & & 0.01 & 0.95 & 0.00 & 0.24 & 0.48 & 0.01 & 0.00 & 0.01 & 0.92 \\
\hline \%perforate sp. & 0.21 & 0.50 & 0.42 & -0.33 & -0.63 & -0.14 & 0.32 & 0.48 & 0.19 & 0.46 & & 0.00 & 0.00 & 0.06 & 0.44 & 0.19 & 0.19 & 0.25 & 0.03 \\
\hline \%porcelaneous sp. & -0.05 & -0.30 & -0.71 & -0.04 & 0.57 & 0.55 & 0.12 & -0.52 & 0.50 & -0.01 & -0.65 & & 0.88 & 0.06 & 0.51 & 0.54 & 0.79 & 0.89 & 0.04 \\
\hline \%agglutinated sp. & -0.24 & -0.40 & 0.09 & 0.47 & 0.32 & -0.31 & -0.52 & -0.17 & -0.69 & -0.60 & -0.74 & -0.03 & & 0.43 & 0.67 & 0.25 & 0.13 & 0.16 & 0.30 \\
\hline Absolute densities & -0.07 & 0.17 & 0.36 & 0.18 & -0.16 & -0.30 & -0.27 & 0.16 & 0.05 & -0.22 & 0.35 & -0.35 & -0.15 & & 0.04 & 0.95 & 0.01 & 0.63 & 0.61 \\
\hline Specific richness & 0.66 & 0.46 & 0.17 & -0.10 & -0.21 & 0.01 & 0.02 & 0.31 & 0.02 & 0.14 & 0.15 & -0.13 & -0.08 & 0.38 & & 0.00 & 0.16 & 0.00 & 0.07 \\
\hline Shannon index & 0.74 & 0.52 & 0.05 & -0.34 & -0.33 & 0.23 & 0.30 & 0.28 & 0.15 & 0.45 & 0.25 & -0.12 & -0.22 & -0.01 & 0.82 & & 0.00 & 0.00 & 0.09 \\
\hline Equitability index & 0.52 & 0.31 & -0.14 & -0.28 & -0.26 & 0.27 & 0.42 & 0.08 & 0.17 & 0.57 & 0.25 & -0.05 & -0.29 & -0.48 & 0.27 & 0.69 & & 0.00 & 0.52 \\
\hline ES50 & 0.79 & 0.47 & -0.13 & -0.24 & -0.27 & 0.24 & 0.39 & 0.12 & 0.21 & 0.51 & 0.23 & -0.03 & -0.28 & -0.10 & 0.81 & 0.97 & 0.82 & & 0.33 \\
\hline$\%$ Etstd & 0.24 & 0.36 & 0.26 & 0.10 & -0.21 & -0.24 & -0.08 & 0.97 & -0.40 & -0.02 & 0.41 & -0.38 & -0.20 & 0.10 & 0.34 & 0.32 & 0.12 & 0.193 & \\
\hline
\end{tabular}




\section{Appendix D}

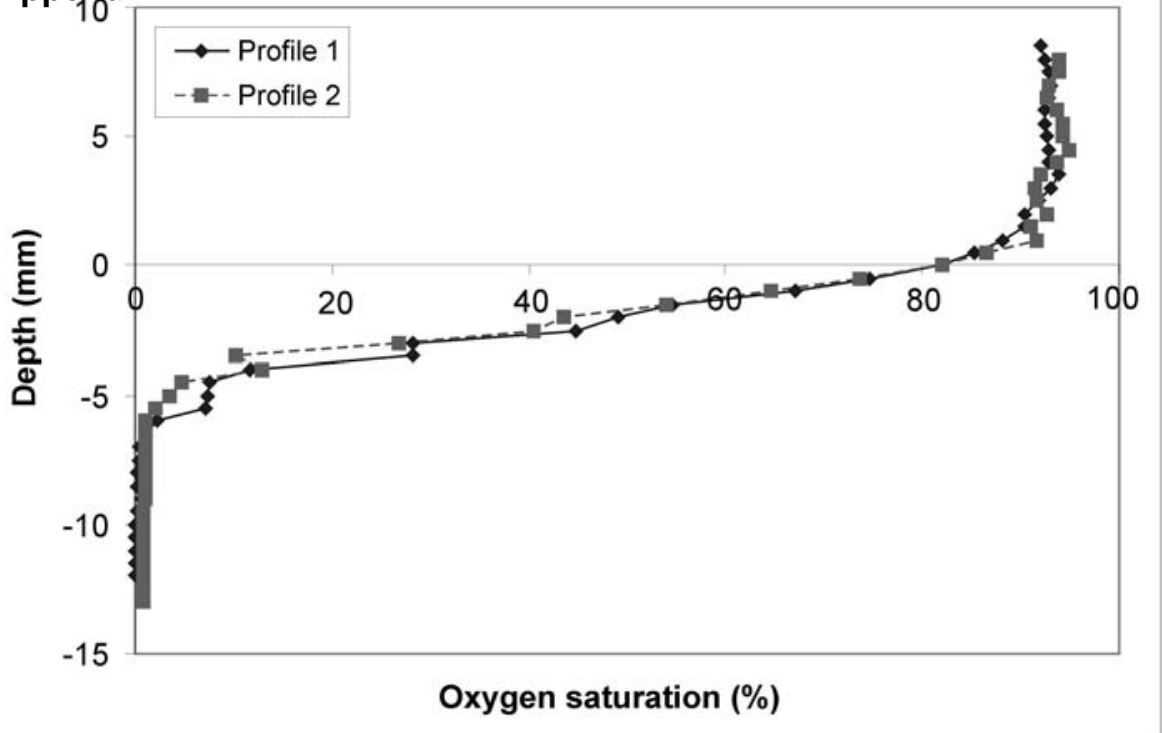


Appendix E: Wilcoxon tests $(Z)$ results and their corresponding probabilities (p) in order to test similarities of major species $(>5 \%)$ between intervals $0-1$ and $0-4 \mathrm{~cm}$.

\begin{tabular}{lccc}
\hline Stations & $\mathbf{n}$ & $\mathbf{Z}$ & $\mathbf{p}$ \\
\hline Grau du Roi & 18 & 0.54 & 0.59 \\
Carteau & 18 & 0.28 & 0.78 \\
Agde Est & 16 & 0.78 & 0.44 \\
Pampelone & 24 & 0.06 & 0.95 \\
Nice & 14 & 0.60 & 0.55 \\
lle Maire & 21 & 0.26 & 0.79 \\
Villefranche & 28 & 0.18 & 0.86 \\
Menton & 29 & 0.18 & 0.85 \\
Collioure & 17 & 1.35 & 0.18 \\
Beauduc & 17 & 0.69 & 0.49 \\
Toulon Grande Rade & 28 & 0.87 & 0.39 \\
Carry & 30 & 0.63 & 0.53 \\
Leucate & 24 & 0.14 & 0.89 \\
Marseille Jetée & 30 & 0.63 & 0.53 \\
\hline
\end{tabular}


Appendix F: Linear correlation (r) between the relative densities of the major species (see Table 2 for the meaning of species abbreviations) and the environmental parameters available for this study. The statistically significant correlations $(\mathrm{p}<0.05)$ are indicated in bold.

\begin{tabular}{|c|c|c|c|c|c|c|c|}
\hline & \multirow{2}{*}{ Water depth } & \multirow{2}{*}{$\begin{array}{c}\% \text { organic } \\
\text { matter }\end{array}$} & \multicolumn{5}{|c|}{ Grain size fraction (\%) } \\
\hline & & & $<63 \mu \mathrm{m}$ & $63-125 \mu \mathrm{m}$ & $125-250 \mu \mathrm{m}$ & $250-500 \mu \mathrm{m}$ & $>500 \mu \mathrm{m}$ \\
\hline Abecc & -0.52 & -0.10 & 0.54 & 0.05 & -0.11 & -0.38 & -0.40 \\
\hline Amami & 0.31 & 0.16 & -0.24 & -0.41 & -0.28 & 0.24 & 0.69 \\
\hline Astel & 0.41 & 0.32 & -0.21 & -0.48 & -0.35 & 0.29 & 0.74 \\
\hline Bgran & -0.38 & -0.39 & -0.26 & 0.41 & 0.39 & -0.19 & -0.15 \\
\hline Bacul & 0.40 & -0.13 & 0.24 & 0.26 & -0.02 & -0.30 & -0.28 \\
\hline Cauri & 0.53 & 0.56 & 0.04 & -0.29 & -0.28 & 0.08 & 0.34 \\
\hline Cloba & 0.46 & 0.28 & -0.31 & -0.38 & -0.16 & 0.52 & 0.46 \\
\hline Ecris & -0.23 & 0.05 & 0.30 & 0.04 & -0.20 & -0.17 & -0.15 \\
\hline Egran & -0.30 & -0.22 & 0.48 & 0.06 & -0.28 & -0.30 & -0.25 \\
\hline Epoey & -0.18 & 0.01 & 0.50 & -0.12 & -0.25 & -0.21 & -0.22 \\
\hline Hboue & 0.49 & 0.51 & -0.08 & -0.30 & -0.18 & 0.19 & 0.35 \\
\hline Nterq & 0.28 & 0.16 & -0.20 & -0.36 & -0.24 & 0.15 & 0.65 \\
\hline Ndepres & -0.20 & -0.21 & -0.08 & 0.44 & 0.07 & -0.15 & -0.19 \\
\hline Nscap & -0.18 & 0.14 & 0.61 & -0.18 & -0.34 & -0.27 & -0.21 \\
\hline Nturg & -0.25 & -0.18 & 0.06 & 0.40 & 0.00 & -0.24 & -0.22 \\
\hline Pmedit & 0.35 & 0.18 & -0.21 & -0.15 & 0.04 & 0.27 & 0.17 \\
\hline Rphle & 0.24 & 0.59 & 0.31 & -0.16 & -0.23 & -0.12 & -0.01 \\
\hline Rglob & 0.35 & 0.23 & -0.34 & -0.48 & -0.29 & 0.40 & 0.77 \\
\hline Spiril & 0.23 & 0.21 & -0.26 & -0.24 & -0.11 & 0.37 & 0.36 \\
\hline Vbrad & -0.06 & 0.47 & 0.50 & -0.11 & -0.27 & -0.28 & -0.16 \\
\hline Along & -0.04 & 0.26 & 0.15 & -0.24 & -0.21 & 0.19 & 0.02 \\
\hline Birreg & 0.12 & -0.15 & -0.26 & -0.07 & 0.21 & 0.27 & 0.04 \\
\hline Qasp & -0.35 & -0.45 & -0.48 & 0.44 & 0.64 & 0.02 & -0.24 \\
\hline Qbosc & -0.13 & -0.18 & -0.26 & -0.05 & 0.43 & 0.14 & -0.06 \\
\hline Qcost & 0.46 & 0.06 & -0.38 & -0.43 & -0.17 & 0.54 & 0.58 \\
\hline Qsemi & 0.19 & 0.05 & -0.08 & -0.10 & -0.03 & 0.13 & 0.11 \\
\hline Sgrata & 0.20 & 0.13 & -0.17 & -0.20 & -0.11 & 0.22 & 0.30 \\
\hline Ttrigo & -0.19 & -0.29 & -0.30 & 0.01 & 0.40 & 0.26 & -0.13 \\
\hline Apseudo & 0.15 & 0.52 & 0.44 & -0.22 & -0.32 & -0.17 & -0.03 \\
\hline Escab & -0.58 & -0.53 & -0.16 & 0.54 & 0.60 & -0.26 & -0.51 \\
\hline LagenamA & -0.03 & -0.08 & -0.03 & 0.06 & 0.04 & 0.16 & -0.16 \\
\hline LagenamB & -0.14 & -0.11 & 0.01 & 0.23 & -0.02 & -0.10 & -0.10 \\
\hline Pfusc & -0.28 & -0.36 & 0.29 & 0.28 & -0.02 & -0.38 & -0.32 \\
\hline Rfusif & 0.18 & 0.01 & -0.11 & -0.29 & -0.18 & 0.25 & 0.33 \\
\hline Rmica & 0.28 & 0.16 & 0.12 & -0.05 & -0.19 & -0.10 & 0.12 \\
\hline Rscorp & 0.31 & 0.37 & 0.07 & -0.12 & -0.17 & -0.04 & 0.16 \\
\hline Rsubfus & 0.19 & 0.31 & 0.18 & -0.13 & -0.27 & -0.03 & 0.10 \\
\hline Rscot & -0.12 & -0.15 & -0.09 & 0.41 & 0.04 & -0.14 & -0.13 \\
\hline Taggl & 0.32 & -0.13 & -0.08 & 0.21 & 0.14 & -0.07 & -0.11 \\
\hline Tsagit & 0.62 & 0.37 & -0.03 & -0.26 & -0.23 & 0.10 & 0.36 \\
\hline
\end{tabular}


Appendix G: Evidence from the literature that support our choice to attribute species to stress-tolerant and sensitive (including epiphytic species) groups.

\section{Tolerant species group}

Bulimina species (e.g. B. marginata, B. aculeata, B. denudata) are typical of environments with high food input (De Rijk et al., 2000; Morigi et al., 2001; Donnici and SerandreiBarbero, 2002; Mendes et al., 2004; Eberwein and Mackensen, 2006). For example, $B$. marginata responds to seasonal fluxes of phytodetritus in the Bay of Biscay by increasing its density (Langezaal et al., 2006). Bulimina spp. have also been considered as good markers of oxygen-poor conditions (Sen Gupta and Machain-Castillo, 1993; Ohga and Kitazato, 1997; Bernhard and Sen Gupta, 1999; van der Zwaan et al., 1999). Cancris auriculus and Rectuvigerina phlegeri are often found in the same assemblages. These species are indicative of eutrophic conditions and stress due to hypoxia (Corliss, 1985; Sen Gupta and MachainCastillo, 1993; Schmiedl et al., 2000; Milker et al., 2009). More precisely, Diz et al. (2006) described $R$. phlegeri as an opportunistic species rapidly developing after labile organic matter inputs. Nonion scaphum and Nonion depressulum are species living in fine sediment with high organic matter inputs (Venec-Peyré, 1984; Mathieu, 1986; Murray, 1991; Debenay et Redois, 1997; Fontanier et al., 2002; Mojtahid et al., 2006). Nonionella turgida, N. stella and Pseudoeponides falsobeccarii are all characteristic of fine-grained sediments with high organic matter contents and would be tolerant or even slightly favoured by stressed conditions such as hypoxia (Venec-Peyré, 1984; Jorissen, 1987; Bernhard and Reimers, 1991; Van der Zwaan and Jorissen, 1991; Barmawidjaja et al., 1992; Bernhard et al., 1997; Duijnstee et al., 2003; Diz et al., 2006). Valvulineria bradyana is considered as an excellent indicator of sediment enriched in organic matter where environmental stress conditions, such as hypoxia, occur periodically (Jorissen, 1987, 1988 ; Fontanier et al., 2002). Finally, Leptohalysis scottii is considered as a strongly opportunistic species because it responds quickly to labile organic matter inputs in the first centimetre of sediment (Scott et al., 2005; Diz et al., 2008; Sabbatini et al., 2012). It can support highly turbid waters (Scott et al., 2005; Mojtahid et al., 2009; Goineau et al., 2011) but would only be weakly tolerant to severe hypoxia (Moodley et al., 1997; Ernst et al., 2002; Duijnstee et al., 2003).

\section{Sensitive species group:}

According to the literature, porcelaneous foraminifera live preferentially in sandy, well oxygenated sediments with relatively low organic matter content (Bizon and Bizon, 1984; 
Jorissen, 1988; Donnici and Serandrei-Barbero, 2002; Schmiedl et al., 2003). Most of the porcellaneous species will therefore be absent from the assemblage in case of a muddy sediment enriched in organic matter (naturally or anthropogenetically). The group of epiphytic species as described in the main text is sensitive to low oxygen conditions. High percentages suggests the presence of seagrass or macroalgae meadow in the vicinity (Pujos, 1976; Spindler, 1980; Bizon and Bizon, 1984; Jorissen, 1987; Murray, 1991; Langer, 1993; Coppa and Di Tuoro, 1995; Guimerans and Currado, 1999; Van der Zwaan et al., 1999; Villanueva Guimerans and Cervera Currado, 1999; Mendes et al., 2004; Panieri et al., 2005; Mojtahid et al., 2006; Schönfeld, 2002; Martins et al., 2007; Milker et al., 2009). In addition to the sessile and temporarily motile species from morphotypes A and B (Langer et al., 1993) considered in our "epiphytic group", we added some species from the motile epiphytic morphotypes $\mathrm{C}$ and $\mathrm{D}$ in the sensitive species. This concerns Reussela spinulosa, Spirillina and Elphidium species. According to a study in the Adriatic Sea, Reussela spinulosa would show a certain preference for a sandy substratum with a low input of clay (Jorissen, 1987). Elphidium crispum shows no specific preference to a particular type of sediment. In the study of Jorissen (1987), this species is found at sites where the organic matter content is slightly elevated but it is very rare in stations under the direct influence of the Po river output. This species is also considered as a motile epiphytic suspension feeder (Langer, 1993). Therefore, this species would not support severe stress conditions. In our material, Elphidium granosum and E. poeyanum are mainly represented by the lidoense and decipiens morphotypes, respectively. These two morphotypes, which have been considered as sensitive by Jorissen (1987), are mainly found in silty to sandy areas with a relatively low organic matter content, probably with well oxygenated bottom waters. 


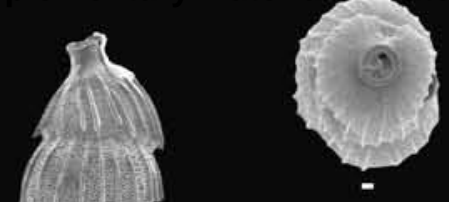

$1 b$
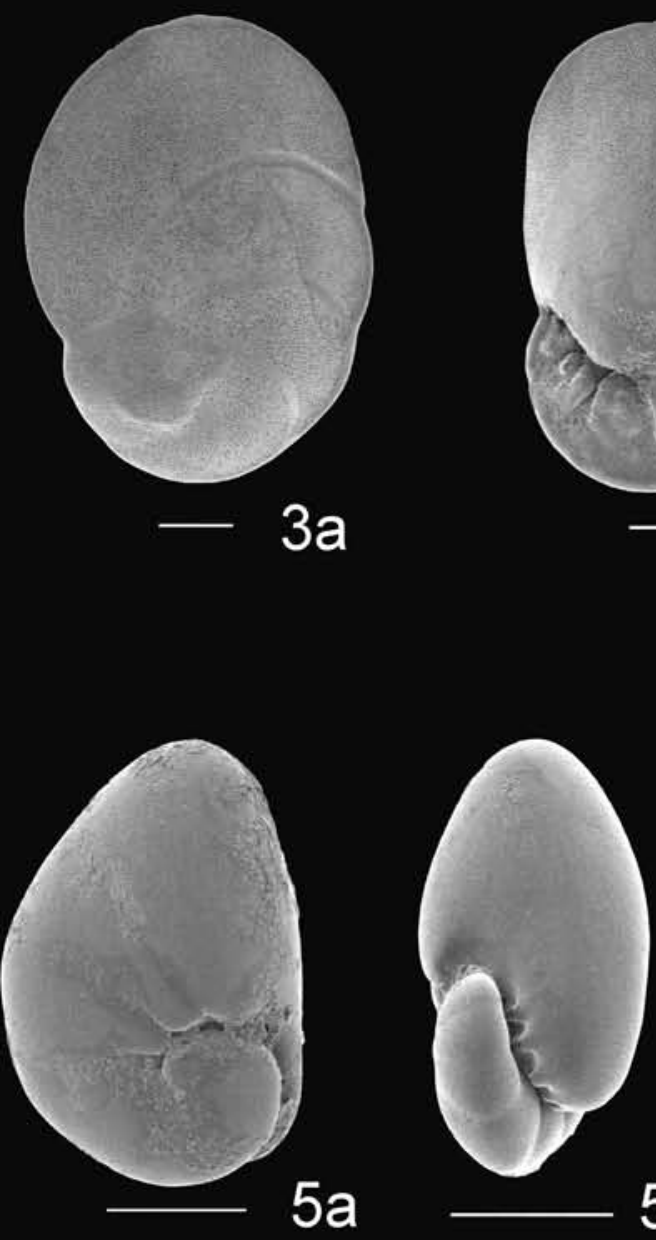

$5 b$
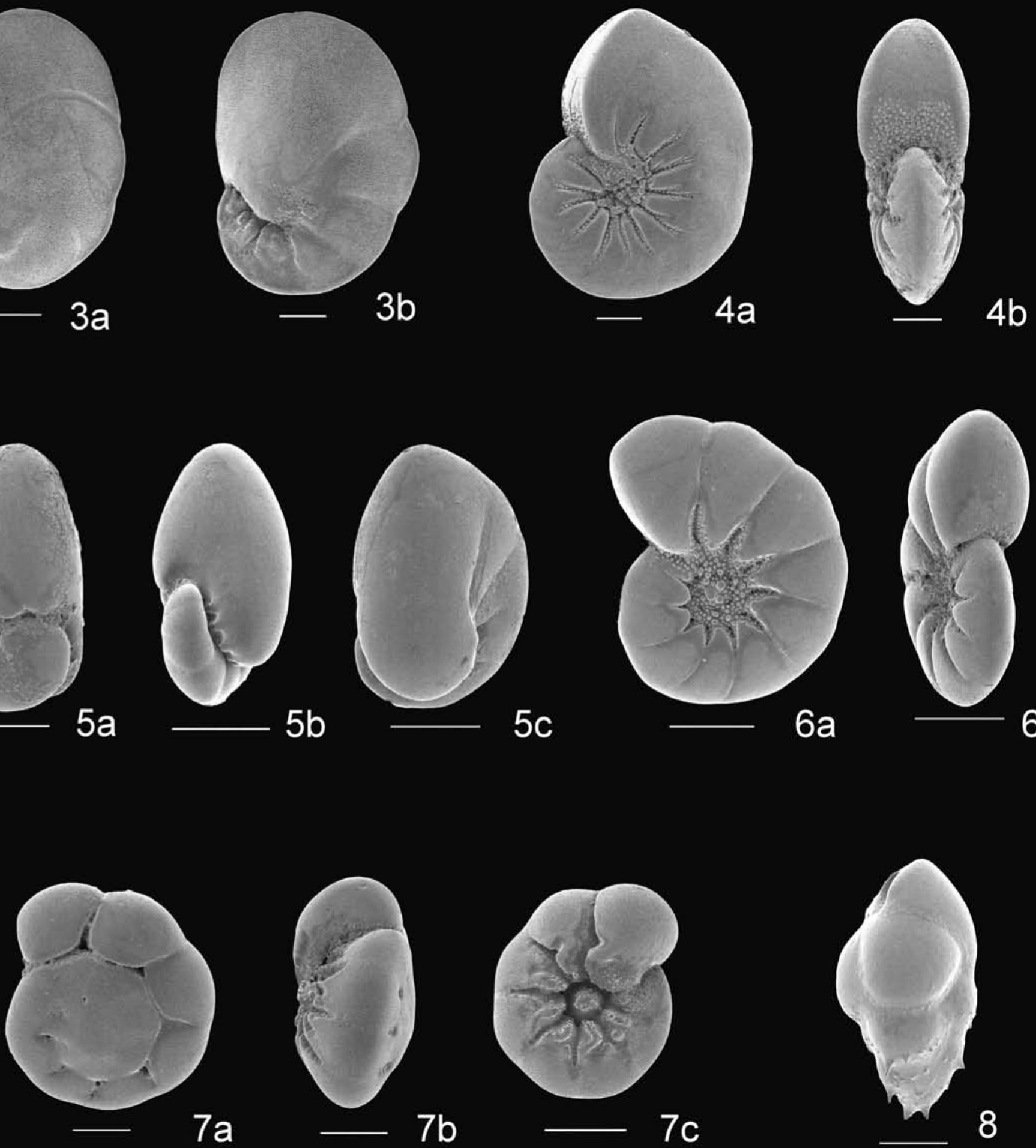

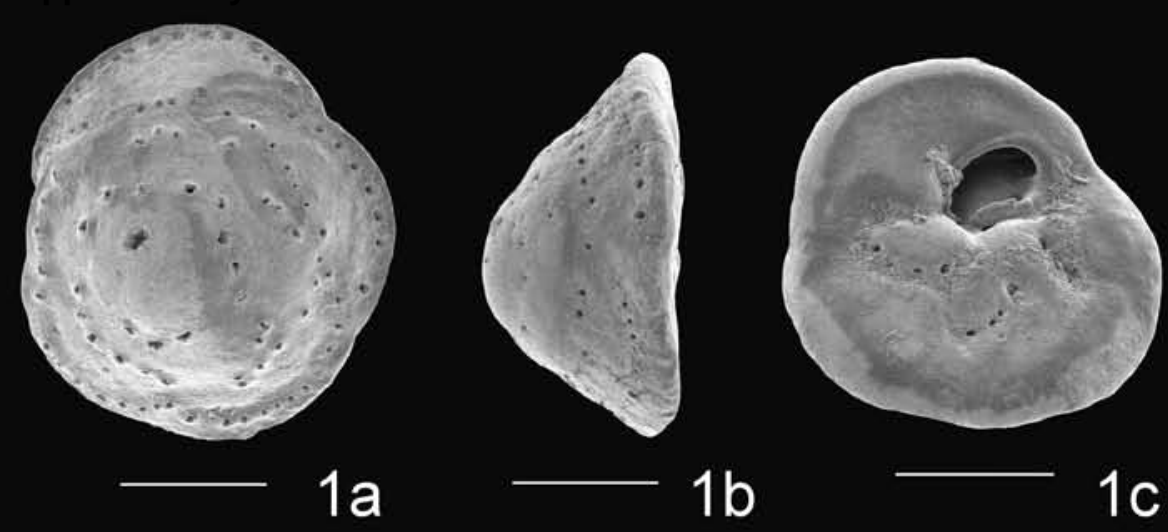

$1 b$

$1 c$
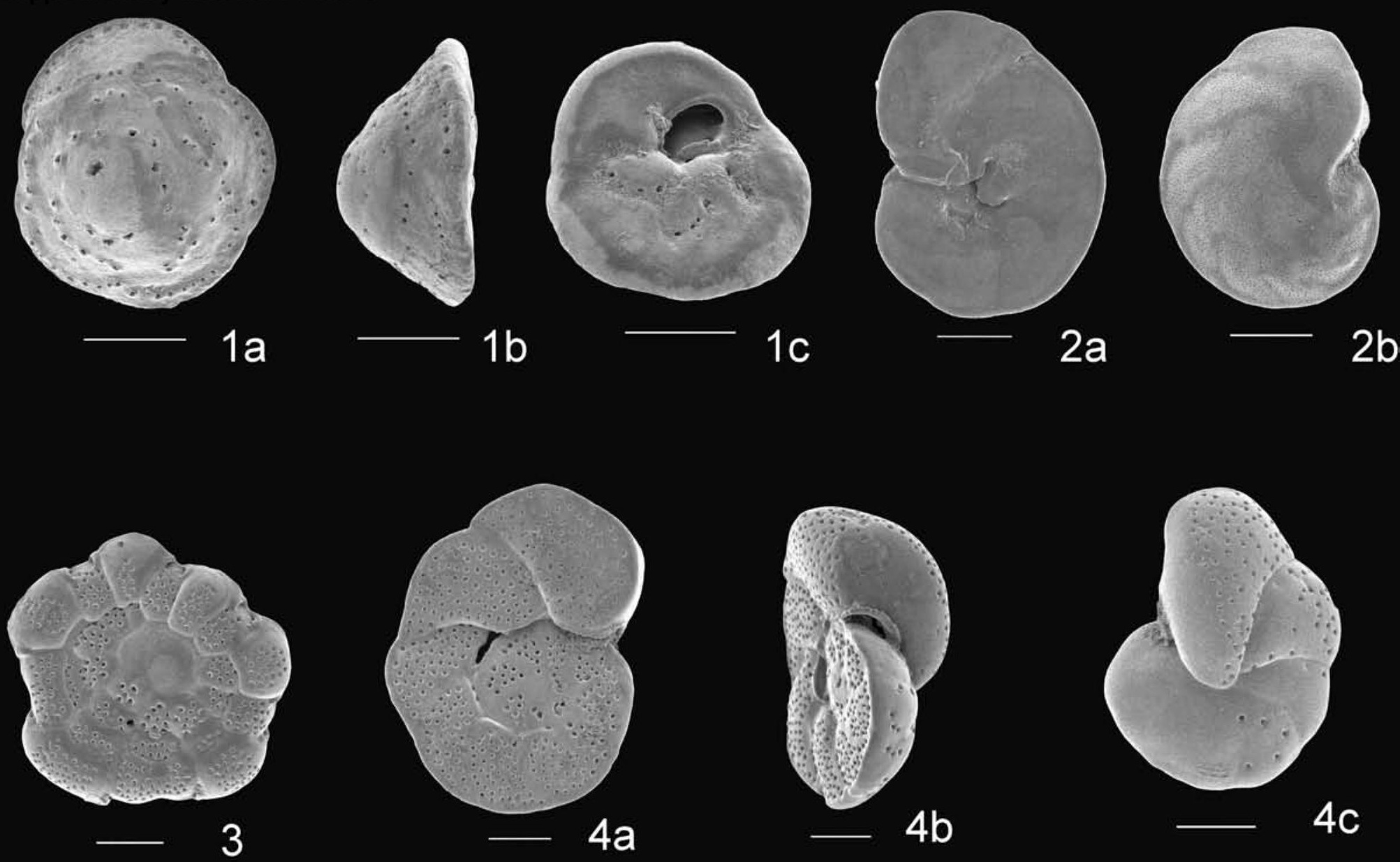

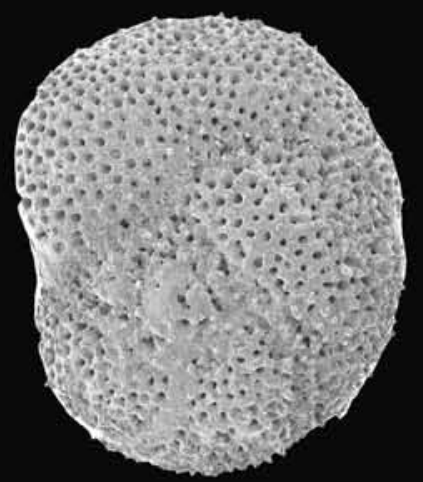

$5 a$
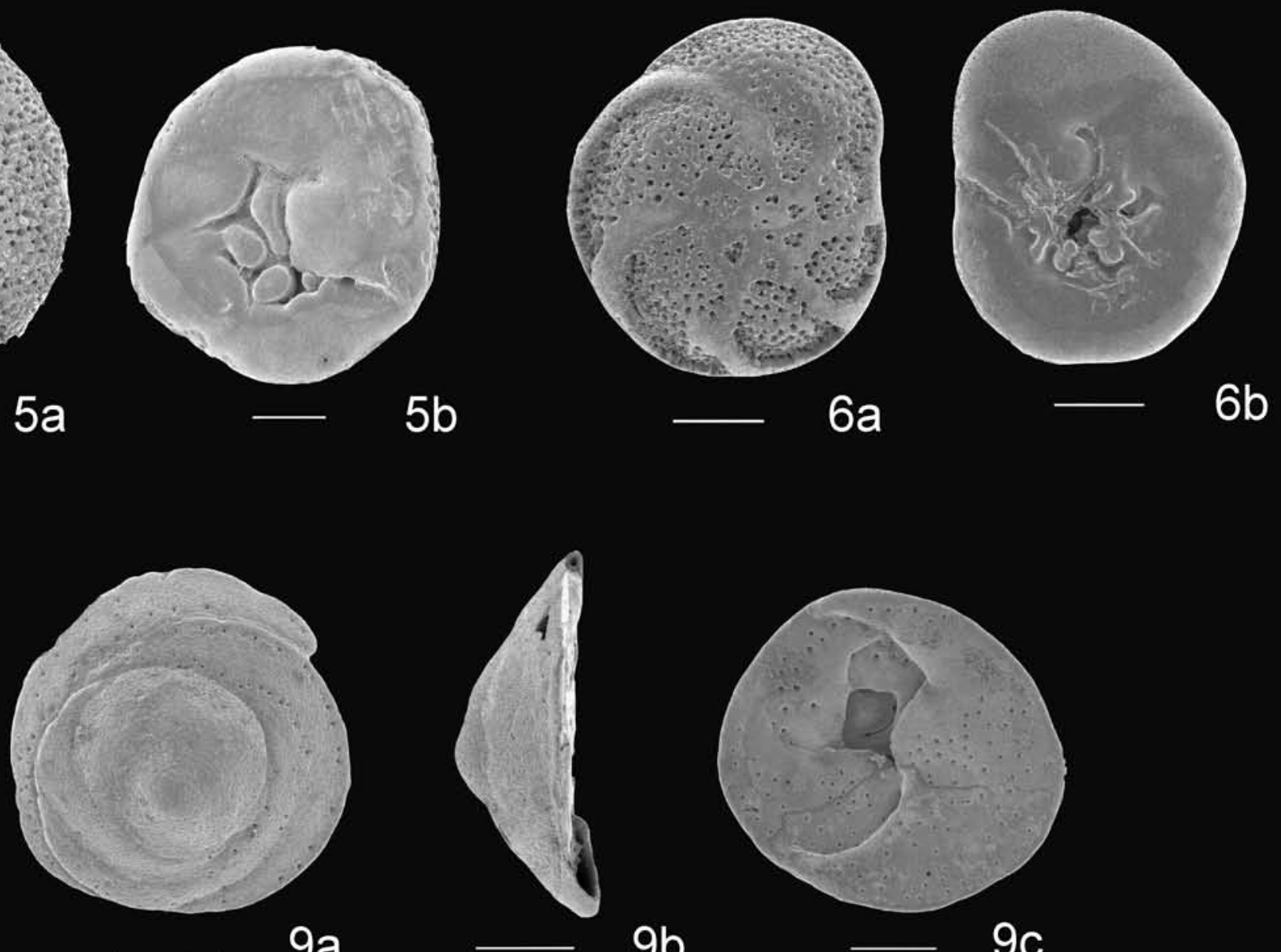

$9 a$

$9 b$

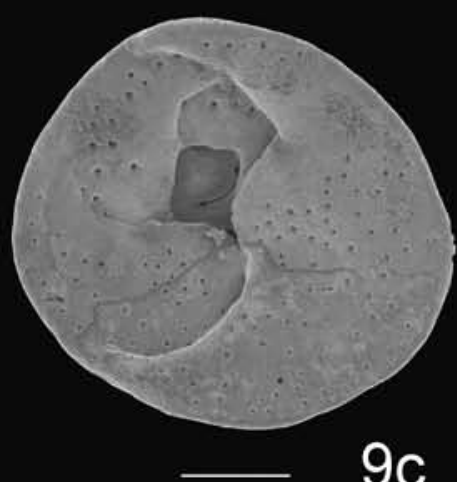



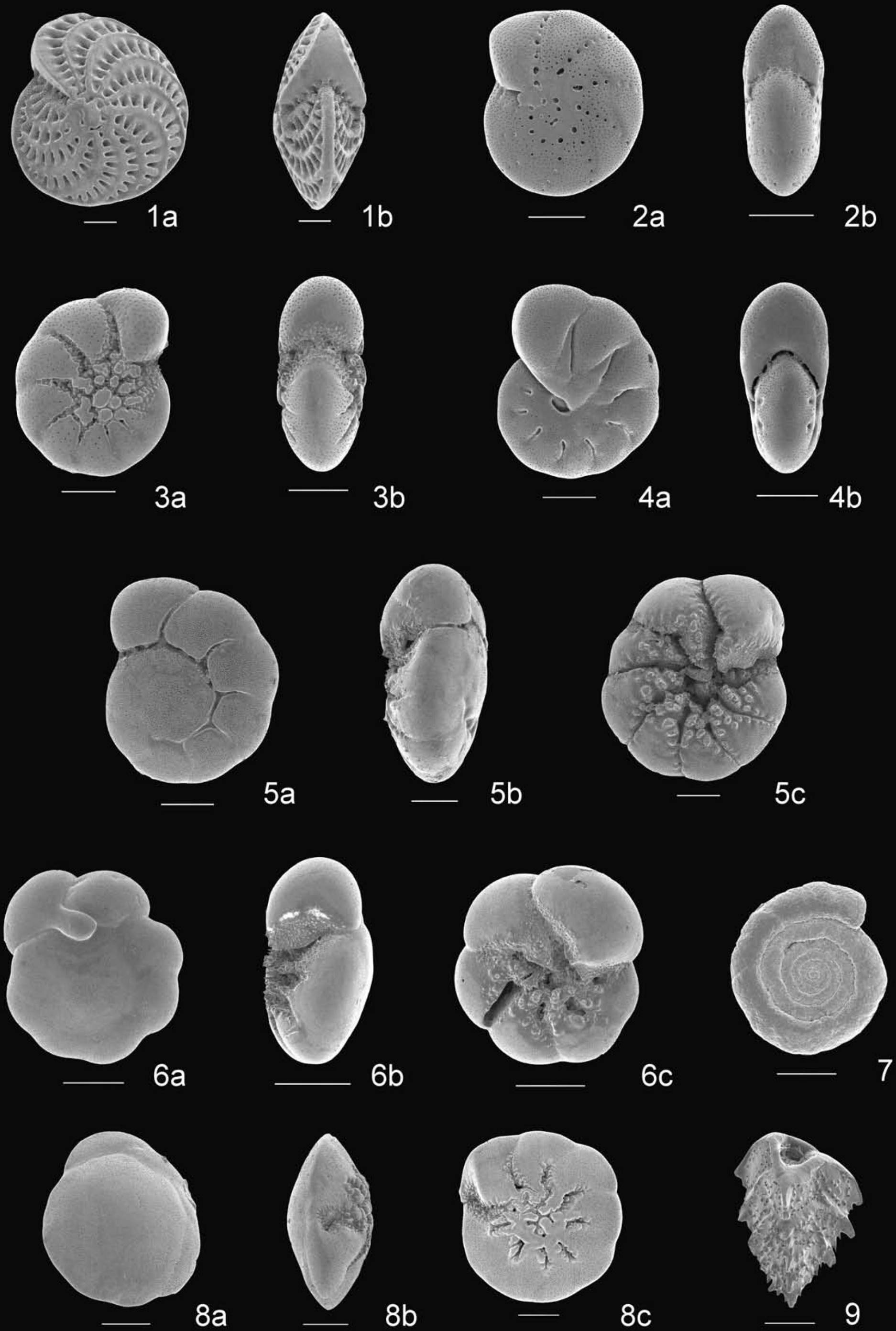

$8 c$

9 
Supplementary Material 2

Supplementary material 2: Number of living (Rose Bengal stained) benthic foraminifera $(>150 \mu \mathrm{m})$ in the first centimetre of sediment standardised for $50 \mathrm{~cm}^{2}$.

\begin{tabular}{|c|c|c|c|c|c|c|c|c|c|c|c|c|c|c|c|c|c|c|c|c|c|c|c|c|c|c|c|c|c|c|c|}
\hline & 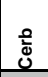 & $\overline{\bar{z}}$ & $\stackrel{0}{\Xi}$ & 宸 & $\begin{array}{l}3 \\
0 \\
\end{array}$ & 䅗 & 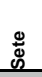 & 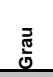 & 产 & 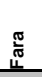 & 莺 & 总 & है & $\begin{array}{l}\frac{8}{\pi} \\
\frac{\pi}{\Sigma} \\
\Sigma\end{array}$ & $\sum_{\Sigma}^{\bar{\omega}}$ & $\begin{array}{l}\frac{0}{\pi} \\
\frac{\pi}{2}\end{array}$ & 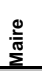 & 胥 & 害 & $\overline{\bar{z}}$ & 亭 & ]్త & 焉 & 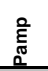 & 离 & 萻 & 艿 & $\stackrel{\Perp}{\check{z}}$ & $\stackrel{5}{\stackrel{5}{5}}$ & 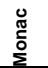 & 竧 \\
\hline \begin{tabular}{|l}
$\begin{array}{l}\text { Perforate } \\
\text { Ammonia beccarii f. beccarii }\end{array}$ \\
\end{tabular} & & & 24 & 8 & 14 & 4 & & & 18 & & & & 1 & 4 & 1 & 5 & 1 & & 5 & & & & & & & 11 & 25 & 8 & & & \\
\hline $\begin{array}{l}\text { Ammonia beccarirt t. beccaril } \\
\text { Ammonia beccarii f. inflata }\end{array}$ & & & 24 & 8 & 14 & 4 & $\begin{array}{c}53 \\
1\end{array}$ & $\begin{array}{l}237 \\
27\end{array}$ & 18 & & $\begin{array}{c}21 \\
5\end{array}$ & $\begin{array}{c}86 \\
1\end{array}$ & 1 & 4 & 1 & 5 & 1 & $\begin{array}{l}3 \\
5\end{array}$ & 5 & & & & & $\begin{array}{l}1 \\
1\end{array}$ & $\begin{array}{l}8 \\
1\end{array}$ & 11 & 25 & 8 & $\begin{array}{l}3 \\
3\end{array}$ & $\begin{array}{l}1 \\
1\end{array}$ & $\begin{array}{l}6 \\
1\end{array}$ \\
\hline $\begin{array}{l}\text { Ammonia parkinsoniana f. parkinsoniana } \\
\text { Ammonia parkinsoniana f. tepida }\end{array}$ & & 1 & 1 & & & & 5 & 11 & $\begin{array}{l}3 \\
3\end{array}$ & & & $\begin{array}{l}4 \\
6\end{array}$ & & & & & 1 & & & & & 1 & & & 1 & & $\begin{array}{l}4 \\
4\end{array}$ & & & & \\
\hline $\begin{array}{l}\text { Ammonia perlucida } \\
\text { Amphicoryna intercellularis }\end{array}$ & & & & & & & & 1 & & & 1 & 1 & & & & & & & & & & & & & & & & & & 1 & \\
\hline $\begin{array}{l}\text { Amphicoryna scalaris } \\
\text { Astacolus crepidulus }\end{array}$ & & & & & & & & & & & & & 1 & & & & & & & & & & & & & & & & & $\begin{array}{l}3 \\
1\end{array}$ & \\
\hline $\begin{array}{l}\text { Astacolus sp. } \\
\text { Asterigerinata mamilla }\end{array}$ & 3 & & & & 9 & & $\begin{array}{l}1 \\
1\end{array}$ & & & & & & 6 & 4 & 18 & 3 & & 1 & 1 & 10 & 10 & 4 & 5 & 24 & 21 & 8 & & & 25 & & 1 \\
\hline $\mid \begin{array}{l}\text { Astrononion stelligerum } \\
\text { Bolivina dilatata }\end{array}$ & & & & & & & & & & & 1 & & 5 & 3 & 6 & & 1 & & & 10 & 4 & 3 & 6 & 8 & 8 & 1 & & & 18 & & 1 \\
\hline \begin{tabular}{|l} 
Bolivina spathulata \\
Buccella granulata
\end{tabular} & & & 5 & 3 & 58 & 14 & 9 & 4 & 9 & 8 & 1 & 4 & & 3 & & 1 & 3 & 20 & 1 & 4 & 1 & 3 & 5 & 6 & 1 & 5 & 16 & 11 & 4 & & \\
\hline $\begin{array}{l}\text { Buccella sp. } \\
\text { Bulimina aculeata }\end{array}$ & 1 & & 13 & 14 & & & 15 & 16 & 3 & & 1 & 1 & & & & & & & & & & & & & & 3 & 3 & 10 & 1 & 61 & 44 \\
\hline \begin{tabular}{|l} 
Bulimina costata \\
Bulimina marginata
\end{tabular} & & & & & & & & 1 & & & & & & & & & & & & & & & & & & & & & & 4 & \\
\hline $\begin{array}{l}\text { Buliminella elegantissima } \\
\text { Cancris auriculus }\end{array}$ & & & & & & & 3 & 1 & & & 3 & & & & & & & & 8 & 43 & & & . & 25 & 6 & & & & 28 & & \\
\hline \begin{tabular}{|l} 
Cancris auriculus \\
Cassidulina carinata
\end{tabular} & & & & & & & 0 & & & & 3 & 8 & 72 & 8 & 110 & 9 & 14 & 1 & 8 & 43 & & 1 & 6 & 25 & 6 & & & & 28 & $\begin{array}{l}15 \\
1\end{array}$ & 13 \\
\hline $\begin{array}{l}\text { Cassidilina oblonga } \\
\text { Cibicides lobatulus } \\
\text { Coryphostoma sp. }\end{array}$ & 8 & & & & 8 & & 6 & & & & 1 & 1 & 24 & 3 & 30 & 14 & 9 & 5 & 8 & $\begin{array}{l}1 \\
9\end{array}$ & 1 & 3 & 5 & 3 & 10 & 9 & & & 20 & $\begin{array}{l}9 \\
8\end{array}$ & $\begin{array}{l}3 \\
4\end{array}$ \\
\hline $\begin{array}{l}\text { Dentalina bradyensis } \\
\text { Dentalina sp. }\end{array}$ & & & & & & & & & & & 1 & r & & & & & & & & 1 & & & & & & & & 1 & & & \\
\hline $\begin{array}{l}\text { Elphidium advenum } \\
\text { Elphidium complanatum }\end{array}$ & 4 & 1 & 1 & 3 & 16 & 5 & 1 & & & 1 & & & & & & & & & & & & & 1 & 3 & & 4 & & r & & & \\
\hline Elphidium crispum & 1 & 3 & 1 & 1 & & & 1 & 1142 & & & 1 & 15 & & & 4 & & & & & 1 & & & 1 & & 13 & 3 & 1 & & & & \\
\hline \begin{tabular}{|l} 
Elphidium granosum \\
Elphidium macellum
\end{tabular} & & 4 & 8 & 3 & 1 & & 5 & 49 & 20 & & & 4 & & & 3 & & & 3 & 8 & 3 & 1 & & & & & & & & & & 3 \\
\hline $\begin{array}{l}\text { Elphidium maioricense } \\
\text { Elphidium poeyanum f. decipiens }\end{array}$ & & & 1 & 1 & & & 1 & 6 & 10 & & & 64 & & & 15 & & & 1 & 3 & & & & & & 8 & $\begin{array}{l}1 \\
1\end{array}$ & & & & 4 & \\
\hline 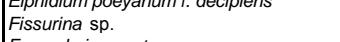 & & & & & & & & & & & & 04 & 5 & & 10 & & & 1 & 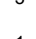 & 4 & & & 1 & 1 & 6 & & & & & 1 & \\
\hline $\begin{array}{l}\text { Fursenkoina acuta } \\
\text { Fursenkoina complanata }\end{array}$ & & & & & & & & & & & 1 & 1 & & & & & & & 1 & & & & & & 3 & 3 & & & & 3 & 1 \\
\hline $\begin{array}{l}\text { Gavelinopsis phlegeri } \\
\text { Glabratella patelliformis }\end{array}$ & & 1 & 6 & 6 & 5 & & 10 & & & & & 3 & 3 & & 1 & & 5 & 1 & & & & & & 1 & 1 & 3 & & 1 & 4 & 5 & 5 \\
\hline $\begin{array}{l}\text { Glandulina laevigata } \\
\text { Glandulina ovulata }\end{array}$ & 1 & & & & & & & & & & & & & & & & & & & 1 & & & & & 1 & & & & & & 1 \\
\hline \begin{tabular}{|l} 
Glandulina sp. \\
Globobulimina affinis
\end{tabular} & 1 & & & & & & & & & & & & 1 & & & & & & & 4 & & & & & & & & & 1 & 21 & \\
\hline $\begin{array}{l}\text { Globocassidulina subglobosa } \\
\text { Globulina gibba }\end{array}$ & & 1 & & & & & & & & & & & & & & & & & & & & 1 & & & & & & & 1 & & 1 \\
\hline $\begin{array}{l}\text { Globulina sp. } \\
\text { Hanzawaia boueana }\end{array}$ & & & & & & & & & & & & & 20 & 5 & 28 & 6 & $\begin{array}{l}3 \\
3\end{array}$ & & & 15 & & 1 & 1 & 3 & 4 & 5 & & & 87 & 8 & 5 \\
\hline $\begin{array}{l}\text { Lagena striata } \\
\text { Lagena sp. }\end{array}$ & & & $\begin{array}{l}1 \\
1\end{array}$ & & 3 & & & & & & & 3 & & & 1 & & 1 & & & & & & & & & & & $\begin{array}{l}3 \\
1\end{array}$ & 1 & 1 & 3 \\
\hline $\begin{array}{l}\text { Lenticulina sp. } \\
\text { Melonis barleeanus }\end{array}$ & & & & & & & & & & & & & 1 & & & & & & & $\begin{array}{l}1 \\
3\end{array}$ & & & & & & & & & & 25 & \\
\hline $\begin{array}{l}\text { Melonis barleaeanus } \\
\text { Neoconorbina terquemi } \\
\text { Neelenticulina variabilis }\end{array}$ & & 1 & & & & & & & & & & & 8 & & 13 & 13 & 1 & 6 & 1 & 9 & 8 & 1 & & 8 & 1 & & & & 4 & . & \\
\hline $\begin{array}{l}\text { Neodosaria lamnulifera } \\
\text { Nodora } \\
\text { Nodoaria sp. }\end{array}$ & & & & & & & & & & & 1 & & & & & & & & & & & & & & & & & & & & \\
\hline $\begin{array}{l}\text { Nonion depressulum } \\
\text { Nonion scaphum }\end{array}$ & 1 & 4 & $\begin{array}{l}131 \\
16\end{array}$ & $\begin{array}{c}11 \\
8\end{array}$ & $\begin{array}{l}6 \\
4\end{array}$ & $\begin{array}{l}1 \\
1\end{array}$ & $\begin{array}{l}4 \\
8\end{array}$ & $\begin{array}{l}34 \\
57\end{array}$ & 29 & & 21 & 67 & 66 & 4 & 48 & 1 & & & & & & & & & & 1 & & & & & 1 \\
\hline
\end{tabular}


Supplementary material 3: Taxonomical list of the major species identified in this study.

\begin{tabular}{|c|c|}
\hline Species & eferences \\
\hline 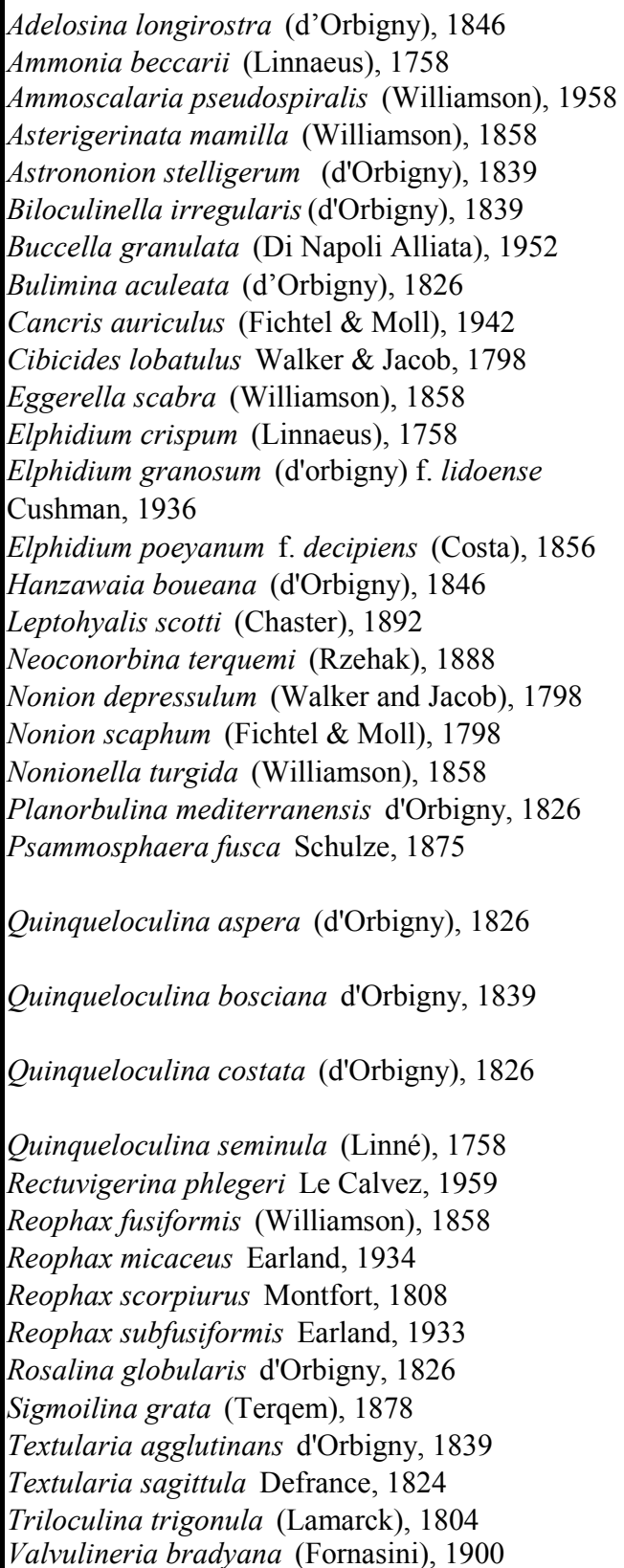 & $\begin{array}{l}\text { Jorissen (1987), pl. 2, fig. 14 } \\
\text { Jorissen (1988), pl. 5, figs. 1-4 } \\
\text { Jones (1994), pl. 33, figs. 1-4 } \\
\text { Jorissen (1987), pl. 3, fig. 1 } \\
\text { Jones (1994), pl. 109, figs. 3-4 } \\
\text { d'Orbigny (1839), pl. 8, figs. 20-21 } \\
\text { Jorissen (1987), pl. 3, fig. 5 } \\
\text { Jones (1994), pl.51, figs. 7-9 } \\
\text { Jones (1994), pl. 106, fig. } 4 \\
\text { Jones (1994), pl. 93, fig. 1 } \\
\text { Jones (1994), pl. 47, figs. 15-17 } \\
\text { Jorissen (1987), pl. 3, fig. 8 } \\
\text { Jorissen (1988), pl. 17, figs. 1-4 } \\
\text { Jorissen (1988), pl. 20, figs. 2-3 } \\
\text { Jorissen (1987), pl. 3, fig. 10 } \\
\text { Sgarrella et al. (1993), pl. 2, fig. 5 } \\
\text { Jorissen (1987), pl. 3, figs. 3-4 } \\
\text { Jorissen (1987), pl. 2, fig. 7 } \\
\text { Jones (1994), pl. 109, fig. 12 } \\
\text { Jones (1994), pl. 109, figs. 17-19 } \\
\text { Jones (1994), pl. 92, fig. 1 } \\
\text { Jones (1994), pl. 18, figs. 1-8 } \\
\text { Jorissen (1987), pl. 3, fig. 2; in this species, we lumped } \\
\text { different morphotypes (f. aspera, f. rugosa, f. } \\
\text { berthelotiana, f. quadrata ) } \\
\text { Sgarrella } \text { et al. (1993), pl. 6, figs. 8-9 } \\
\text { Milker and Schmiedl (2012), pl. 15, figs. 17-19; in this } \\
\text { species, we lumped different morphotypes (f. costata, f. } \\
\text { limbata, f. disparilis, f. lucida) } \\
\text { Jones (1994), pl. 5, fig. 6 } \\
\text { Schiebel (1992), pl. 3, figs. 10a-d } \\
\text { Jones (1994), pl. 30, figs. 7-10 } \\
\text { Timm (1992), pl. 2, fig. 6 } \\
\text { Loeblich and Tappan (1988), pl. 44, figs. 1-3 } \\
\text { Timm (1992), pl. 2, fig. 1 } \\
\text { Milker and Schmiedl (2012), pl. 22, figs. 17-18 } \\
\text { Sgarrella et al. (1993), pl. 9, fig. 9 } \\
\text { Cimerman and Langer (1991), pl. 10, figs. 1-2 } \\
\text { Jorissen (1987), pl. 3, fig. 12 } \\
\text { Jorissen (1987), pl. 2, fig. 13 } \\
\text { Jorissen (1987), pl. 4, fig 1-2 }\end{array}$ \\
\hline
\end{tabular}


Supplementary material 4: Loadings on the species on the 2 first axis of the PCA performed on the relative densities of the major species ( $>5 \%$ ) of the 31 stations (see Table 2 for the meaning of species abbreviations). The percentage of variance explained by the axes is indicated in parenthesis.

\begin{tabular}{|c|c|c|}
\hline & PCA1 (35.4\%) & PCA2 (13.8\%) \\
\hline$\overline{A b e c c}$ & 0.02 & -0.24 \\
\hline Amami & -0.09 & 0.10 \\
\hline Astel & -0.05 & 0.05 \\
\hline Bgran & 0.17 & 0.05 \\
\hline Bacul & 0.01 & -0.01 \\
\hline Cauri & -0.16 & 0.10 \\
\hline Cloba & -0.06 & 0.07 \\
\hline Ecris & -0.08 & -0.91 \\
\hline Egran & 0.00 & -0.04 \\
\hline Epoey & -0.02 & -0.04 \\
\hline Hboue & -0.07 & 0.04 \\
\hline Nterq & -0.06 & 0.06 \\
\hline Ndepres & 0.02 & -0.03 \\
\hline Nscap & -0.07 & -0.07 \\
\hline Nturg & 0.02 & -0.03 \\
\hline Pmedit & -0.02 & 0.03 \\
\hline Rphle & -0.07 & 0.02 \\
\hline Rglob & -0.11 & 0.12 \\
\hline Spiril & -0.03 & 0.03 \\
\hline Vbrad & -0.04 & -0.01 \\
\hline Along & -0.04 & 0.04 \\
\hline Birreg & 0.00 & 0.01 \\
\hline Qasp & 0.22 & 0.09 \\
\hline Qbosc & 0.02 & 0.00 \\
\hline Qcost & -0.05 & 0.06 \\
\hline Qsemi & 0.01 & 0.02 \\
\hline Sgrata & -0.03 & 0.03 \\
\hline Ttrigo & 0.12 & 0.06 \\
\hline Apseudo & -0.09 & 0.02 \\
\hline Escab & 0.89 & -0.04 \\
\hline LagenamA & 0.03 & 0.08 \\
\hline LagenamB & 0.01 & 0.04 \\
\hline Pfusc & 0.05 & 0.00 \\
\hline Rfusif & -0.12 & 0.15 \\
\hline Rmica & 0.02 & 0.01 \\
\hline Rscorp & -0.02 & 0.01 \\
\hline Rsubfus & -0.04 & -0.11 \\
\hline Rscot & 0.00 & 0.00 \\
\hline Taggl & -0.02 & 0.02 \\
\hline Tsagit & -0.03 & 0.02 \\
\hline
\end{tabular}


Supplementary material 5: Cluster analysis (R-mode) based on the relative densities of major species $(>5 \%)$ in the 31 stations using paired group algorithm and correlation similarity measures (see Table 2 for the meaning of species abbreviations).

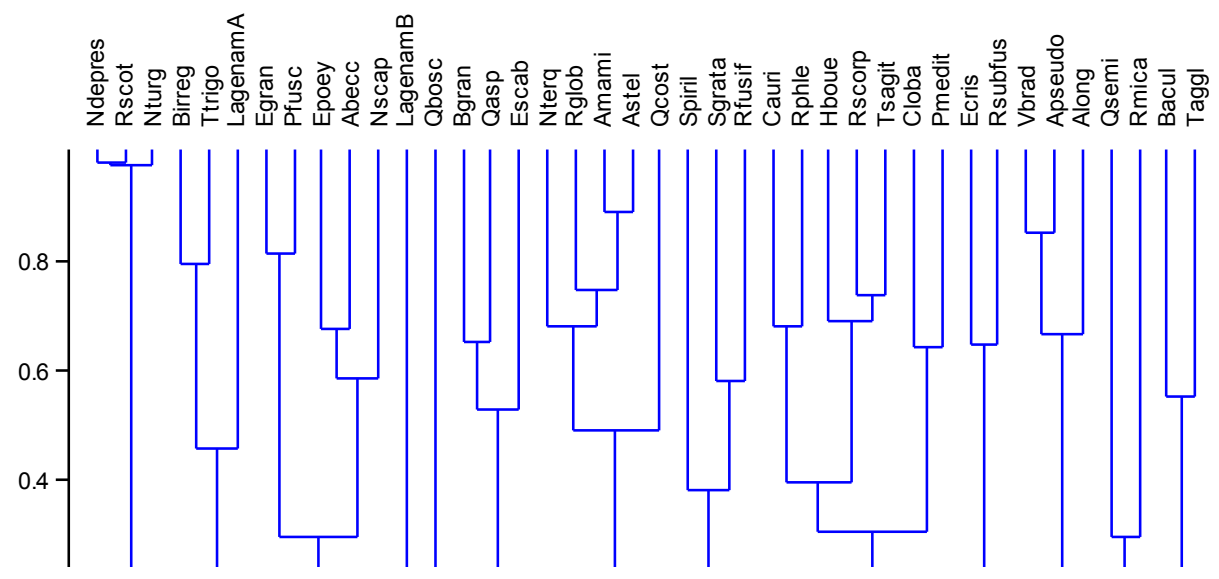

